UNIVERSIDADE DE SÃO PAULO

FACULDADE DE ECONOMIA, ADMINISTRAÇÃO E CONTABILIDADE DEPARTAMENTO DE ADMINSITRAÇÃO PROGRAMA DE PÓS-GRADUAÇÃo EM ADMINISTRAÇÃO

\title{
VARIÁVEIS DE DECISÃO DE MARKETING EM SERVIÇOS DE DEMANDA NÃO DESEJADA: DOIS CASOS NO SETOR DE SEGUROS
}

Camila Gil

Orientador: Prof. Dr. Marcos Cortez Campomar

SÃO PAULO 
Profa. Dra. Suely Vilela

Reitora da Universidade de São Paulo

Diretor da Faculdade de Economia, Administração e Contabilidade Prof. Dr. Carlos Roberto Azzoni

Chefe do Departamento de Administração

Prof. Dr. Isak Kruglianskas

Coordenador do Programa de Pós-Graduação

Prof. Dr. Lindolfo Galvão de Albuquerque 
CAMILA GIL

\title{
VARIÁVEIS DE DECISÃO DE MARKETING EM SERVIÇOS DE DEMANDA NÃO DESEJADA: DOIS CASOS NO SETOR DE SEGUROS
}

\author{
Dissertação apresentada ao Departamento de \\ Administração da Faculdade de Economia, \\ Administração e Contabilidade da \\ Universidade de São Paulo para obtenção do \\ título de Mestre em Administração.
}

Orientador: Prof. Dr. Marcos Cortez Campomar 


\section{FICHA CATALOGRÁFICA}

Elaborada pela Seção de Processamento Técnico do SBD/FEA/USP

\section{Gil, Camila}

Variáveis de decisão de marketing em serviços de demanda não desejada: dois casos no setor de seguros / Camila Gil. -- São Paulo, 2008.

$157 \mathrm{p}$.

Dissertação (Mestrado) - Universidade de São Paulo, 2008 Bibliografia.

1. Marketing de serviços 2. Decisão em marketing 3. Estudo de caso I. Universidade de São Paulo. Faculdade de Economia, Administração e Contabilidade II. Título.

$\mathrm{CDD}-658.8$ 
Aos meus pais, tia e irmãos pelo acolhimento e incentivo de toda uma vida. 


\section{AGRADECIMENTOS}

Ao grande mestre Prof. Dr. Marcos Cortez Campomar que me deu grandes lições teóricas e de vida em cada minuto de sua orientação. Sou grata, fiel e discípula.

À Profa. Dra. Ana Akemi Ikeda pelos momentos de ensinamento, reflexão e descontração. Seu afeto me foi de grande motivação.

Ao Prof. Dr. Edson Crescitelli, que com francas conversas muitas vezes me fez refletir sobre a vida acadêmica e pessoal.

Aos professores da FEA USP que contribuíram das maneiras mais diversas para minha formação.

À meus pais, que investiram na minha educação e me deram todo o suporte para avançar nos estudos.

À minha tia Miriam, pelo carinho de todas as horas.

À minha irmã pelas sábias elucubrações sobre a vida acadêmica e à minha sobrinha pelos momentos de alegria.

Ao meu irmão, amigo, que me acolheu de braços abertos durante este período do mestrado.

Aos amigos com quem também aprendi e dividi as angustias da vida acadêmica, em especial à Beatriz de Castro e Guilherme Shiraishi.

Ao Ricardo, anjo, que foi meu alicerce nos momentos finais desta dissertação.

À Deus que me permitiu manter o equilíbrio tão escasso em algumas horas.

Agradecer é uma dura tarefa, mas gratidão é algo que não meço. Aqueles que aqui não foram nomeados, certamente não foram esquecidos. 
"Não é no silêncio que os homens se fazem, mas na palavra, no trabalho, na ação-reflexão “. 


\section{RESUMO}

O setor de serviços no Brasil vem crescendo desde a década de 80 e mostra-se como o setor da economia mais importante em países desenvolvidos. O estudo do marketing de serviços nos Estados Unidos e Europa para esse setor ganhou importância desde então, no entanto estudos realizados por acadêmicos brasileiros ainda são escassos. O objetivo desta dissertação foi estudar o gerenciamento das variáveis de decisão de marketing em serviços de demanda não desejada do ponto de vista conceitual e prático. Para tanto, realizou-se extensa fundamentação teórica sobre o gerenciamento de marketing de serviços, mais especificamente sobre as variáveis de decisão produto, preço, distribuição e comunicação, finalizando essa parte com uma análise critica dos serviços de demanda não desejada. Do ponto de vista prático, realizou-se uma pesquisa de cunho exploratório, utilizando o método do estudo de caso, com o intuito de gerar novas idéias sobre o tema. A pesquisa de campo compreendeu o estudo de duas empresas do setor de seguros, que geraram novas idéias sobre o tema central desta dissertação. As análises obtidas dos casos mostraram que as empresas têm consciência da natureza dos serviços que vendem. Na variável preço não é uma variável de diferenciação, já que os preços são extremamente regulamentados no mercado de seguros. A distribuição é feita de maneira semelhante nas duas organizações estudadas, ou seja, por parceiros de negócio e corretores, que tem o papel de vendas. Treinamentos e campanhas de incentivo absorvem a maior parte dos investimentos das empresas. Por fim, identificou-se que as empresas pesquisadas utilizam elementos de comunicação que ampliam a receptividade do consumidor, além de utilizarem as relações públicas e patrocínios como principais ferramentas de comunicação.

Palavras-chave: Marketing de Serviços, Decisão em Marketing, Estudo de Caso. 


\begin{abstract}
The services industry in Brazil has been growing since the 80's and is the most important industry in most developed economies. The study of services marketing in the United States and Europe has been becoming increasingly important ever since, however studies by Brazilian researchers are still scarce. The aim of this dissertation is to study the management of decision variables in marketing for negative demand services, both in a conceptual and practical perspective. With that purpose in mind, an extensive theoretical review about services marketing management was carried out, focusing particularly on decision variables related to price, product, distribution and communication and concluding with a critical analysis of negative demand services. From a practical perspective, an exploratory research using case studies was done. Thus, the field research comprised the study of two insurance companies and resulted in fresh ideas on the central subject of this dissertation. The resulting case analyses have shown that both studied companies are aware of the nature of the services they sell. The price variable is not a differentiation variable, since prices in the insurance industry are subjected to regulations. Distribution is similar on both companies and is executed by business partners and brokers that have in fact the sales role. In-house sales training and reward campaigns account for the majority of the investment expenses of the companies. Finally, it was evidenced that the studied companies use communication elements that increase consumers' receptiveness to their products and employ public relations and sponsorships as their main communication tools.
\end{abstract}

Key Words: Services Marketing, Marketing Decision, Case Study. 



\section{SUMÁRIO}

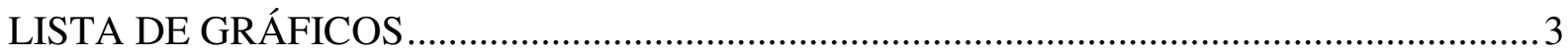

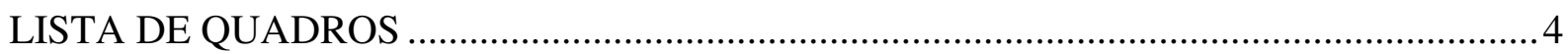

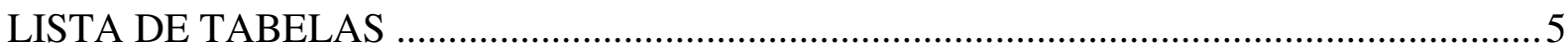

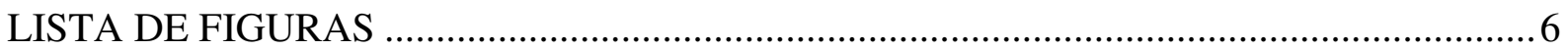

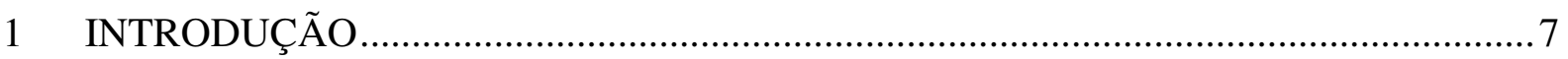

1.1 Apresentação do problema ..............................................................................

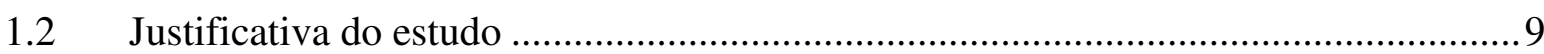

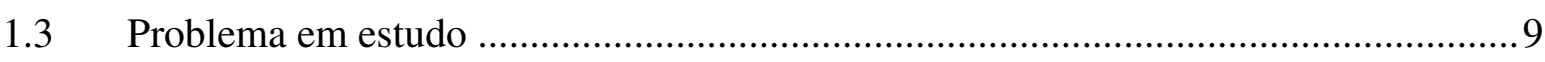

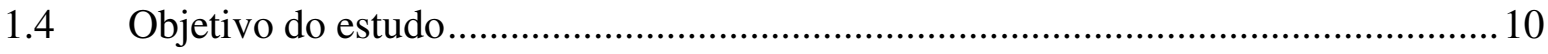

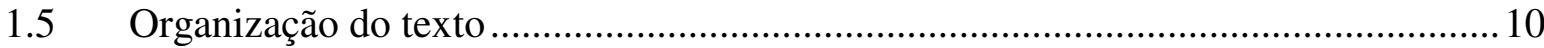

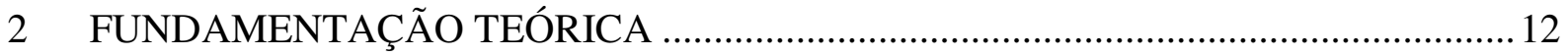

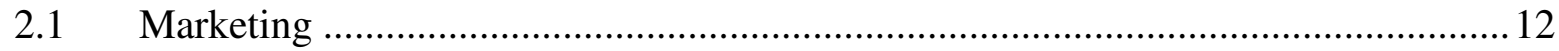

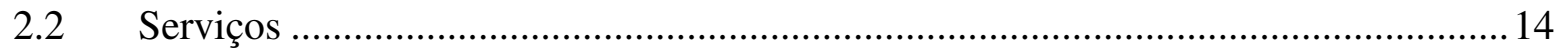

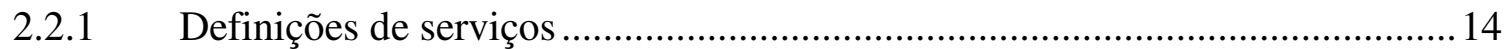

2.2.2 O marketing de serviços e sua importância ........................................................ 16

2.2.3 Características dos serviços ......................................................................... 21

2.3 Propostas de gerenciamento do marketing de serviços .........................................25

2.3.1 Modelo Molecular de Shostack (1977) ..........................................................25

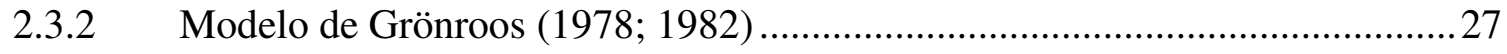

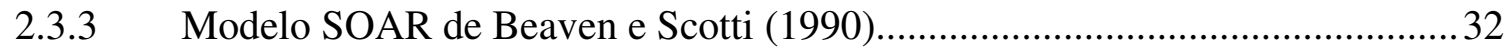

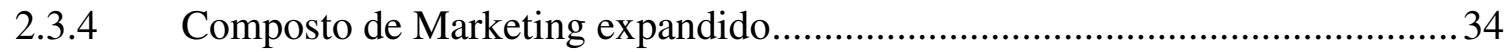

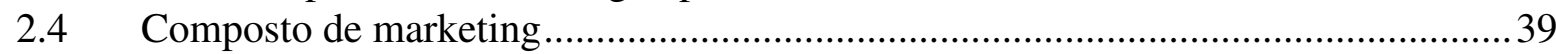

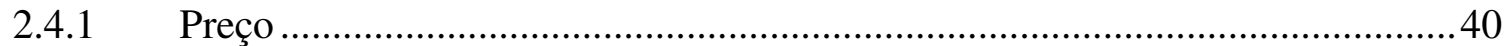

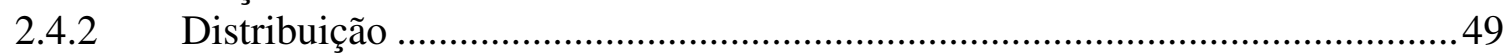

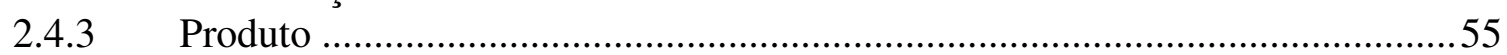

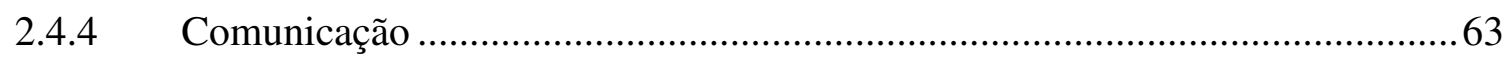

2.5 Serviços de demanda não desejada................................................................. 71

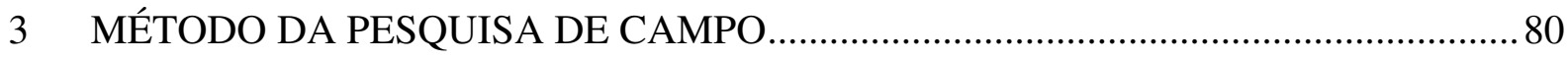

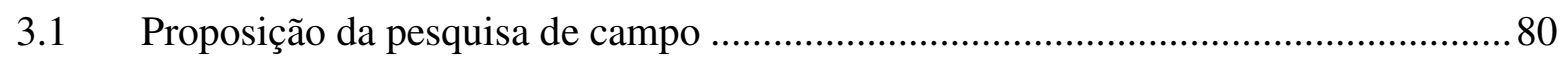

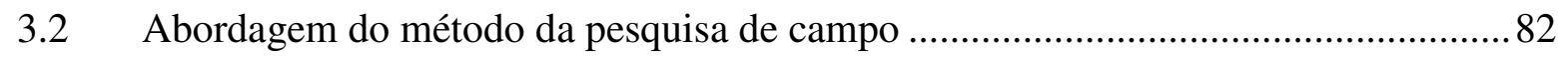

3.3 Escolha do método de estudo de caso para a pesquisa de campo..............................85

3.3.1 Críticas e limitações do método escolhido ………............................................. 87

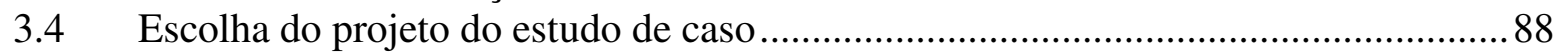

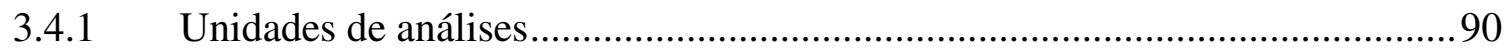

3.4.2 Preparação para a coleta de dados no estudo de caso..................................... 91

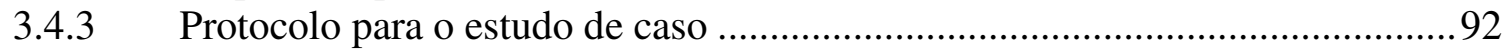




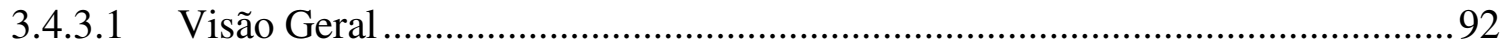

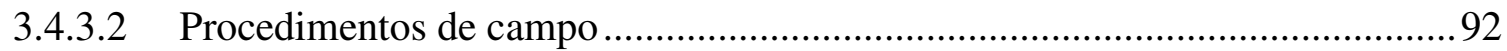

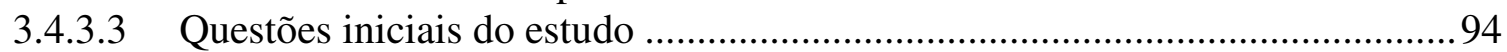

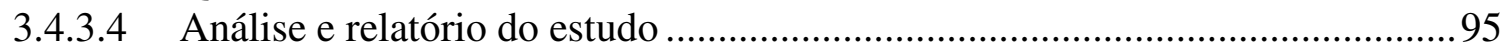

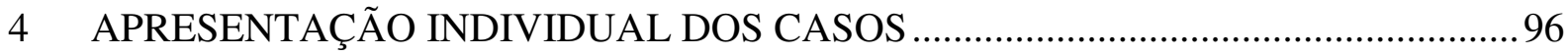

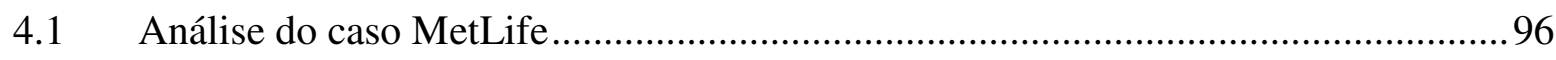

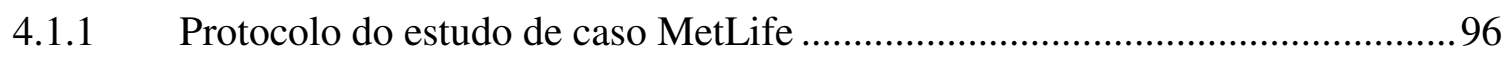

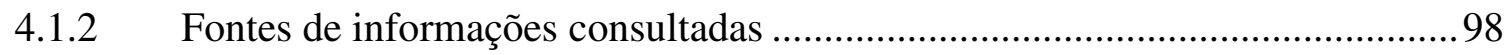

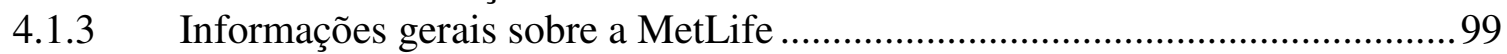

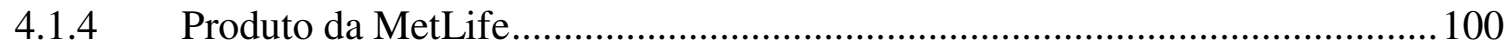

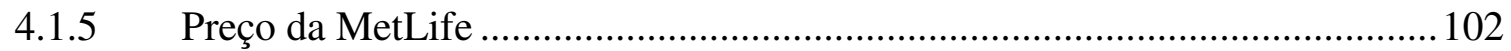

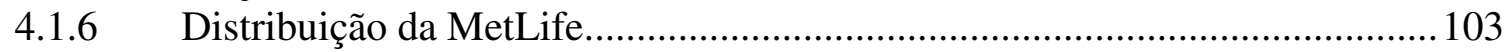

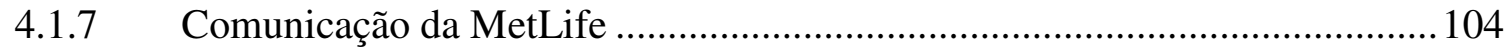

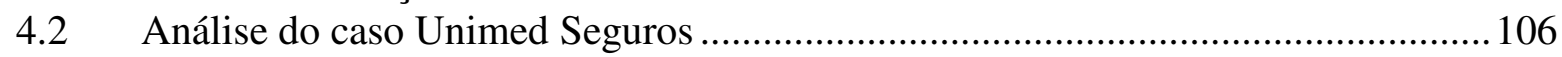

4.2.1 Protocolo do estudo de caso Unimed Seguros ............................................ 106

4.2.2 Fontes de informações consultadas .............................................................. 108

4.2.3 Informações gerais sobre a Unimed Seguros ............................................... 109

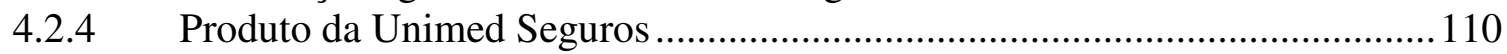

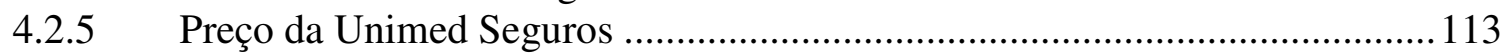

4.2.6 Distribuição da Unimed Seguros ................................................................. 114

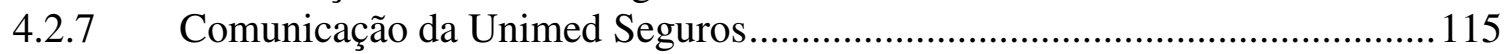

5 ANÁLISE COMPARATIVA DOS CASOS COM A FUNDAMENTAÇÃO TEÓRICA 119

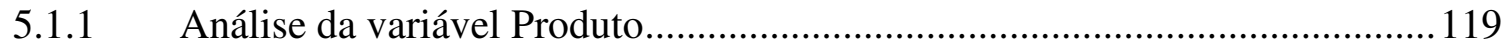

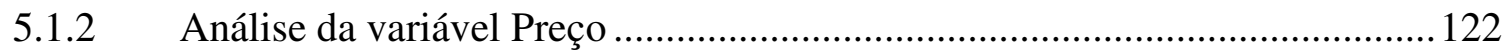

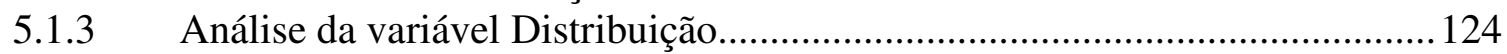

5.1.4 Análise da variável Comunicação ............................................................. 125

6 CONCLUSÕES, LIMITAÇÕES E DESENVOLVIMENTOS FUTUROS .................. 131

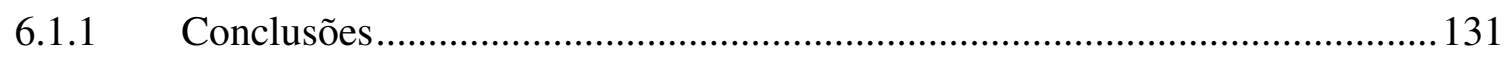

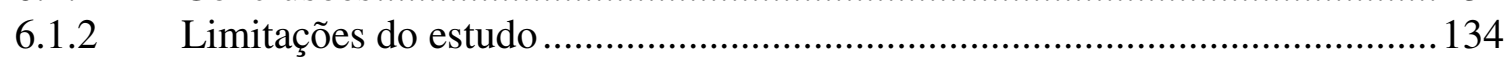

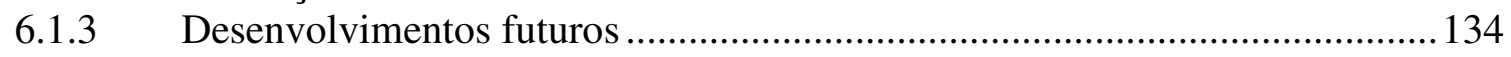

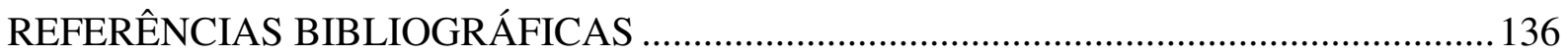

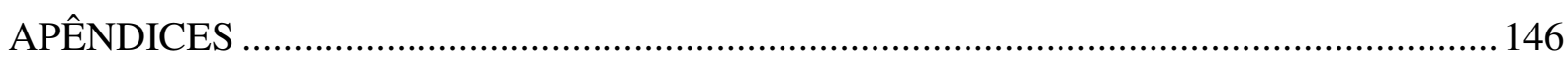

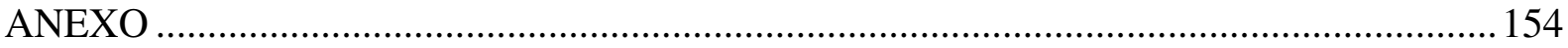




\section{LISTA DE GRÁFICOS}

Gráfico 1 - Evolução da participação dos setores da economia brasileira no PIB. 18

Gráfico 2 - Atendimentos por área realizados pelo PROCON. 19 


\section{LISTA DE QUADROS}

Quadro 1 - Principais publicações acadêmicas que abordam as características diferenciadoras

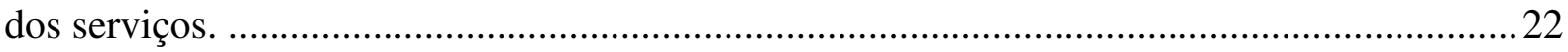

Quadro 2 - Modelos de gerenciamento do marketing de serviços.......................................... 38

Quadro 3 - Resumo sobre as principais considerações para o gerenciamento do preço em

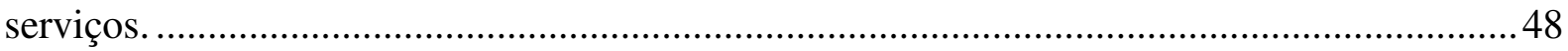

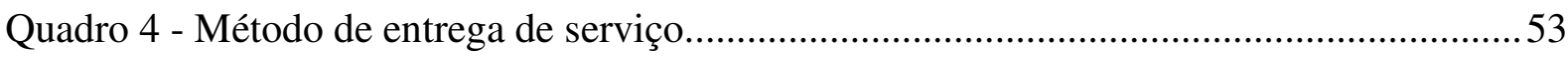

Quadro 5 - Resumo das principais decisões sobre distribuição em serviços...........................55

Quadro 6 - Descrição dos serviços suplementares. .................................................................59

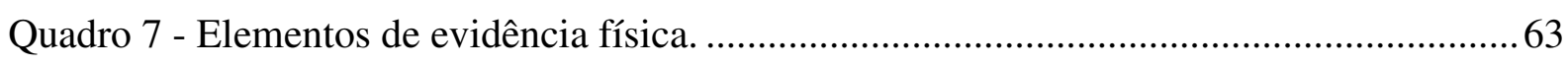

Quadro 8 - Principais ferramentas do mix de comunicação.................................................65

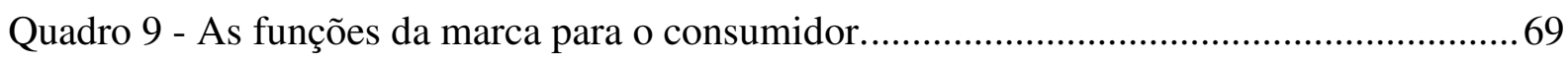

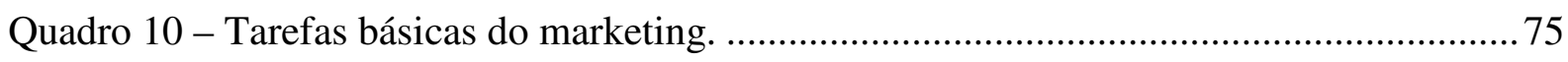

Quadro 11 - Principais Produtos do ramo vida da Unimed Seguros. ..................................112

Quadro 12 - Resumo das características diferenciadoras das organizações estudadas..........119

Quadro 13 - Resumo da análise comparativa ................................................................. 128 


\section{LISTA DE TABELAS}

Tabela 1 - Percentual de participação dos setores de atividade econômica no PIB. 18

Tabela 2 - Ranking das empresas com maior número de reclamações em 2006 e 2007. 19 


\section{LISTA DE FIGURAS}

Figura 1 - Organização do raciocínio de discussão.............................................................. 10

Figura 2 - Predominância de elementos tangíveis e intangíveis na oferta de produtos...........26

Figura 3 - Diagrama do Modelo Molecular. ….................................................................... 27

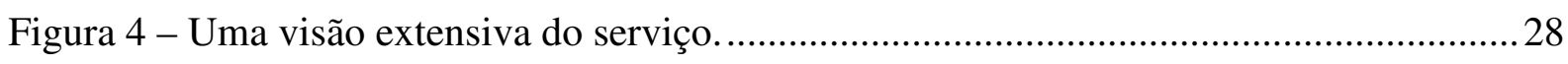

Figura 5 - Um modelo de marketing de serviço. .............................................................. 31

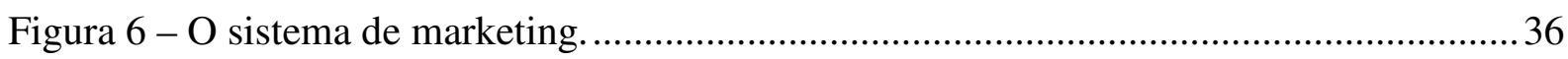

Figura 7 - Resumo das estratégias de precificação para quatro definições de valor. ..............45

Figura 8 - A Flor de Serviços: produto principal cercado por grupos de serviços

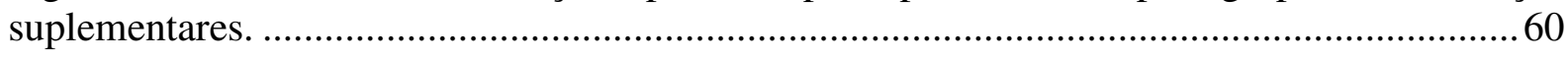

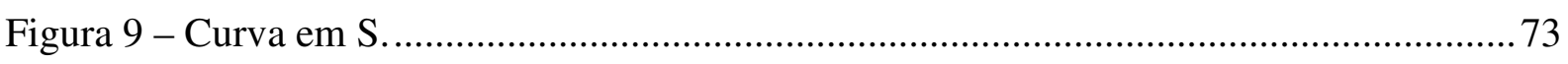

Figura 10 - Tipos básicos de projetos para estudos de caso. ................................................. 89 


\section{INTRODUÇÃO}

\subsection{Apresentação do problema}

A partir da década de 1940 as economias dos países desenvolvidos começaram a apresentar crescimento do setor de serviços (FISK et al. 1993), que está presente em muitas atividades do dia a dia - serviços médicos, odontológicos, telefônicos, educacionais, serviços funerários, de alimentação, entre muitos outros. O crescimento do setor se deu não apenas por meio de empresas especializadas na prestação de serviços, mas também por meio de empresas tradicionalmente manufatureiras que passaram a agregar serviços à oferta de bens como forma de construir vantagem competitiva em relação à concorrência.

Somente a partir da década de 70, início da de 80 , é que os estudos de marketing de serviços ganharam relevância entre os teóricos de marketing de acordo com Fisk et al. (1994), Van der Zwan e Bhamra (2003), Grönroos (2000), Furrer (2003), Lovelock e Gummesson (2004) e desde então, tem sido um campo de estudo em expansão, com discussões polêmicas, porém fundamentadas para o aprimoramento da teoria. A literatura sobre o marketing de serviços trata do marketing de empresas, pessoas ou instituições que ofertam fundamentalmente

serviços. É um campo de estudo separado do tradicional marketing de bens, apesar de sua influência.

Muitos dos autores proeminentes em marketing de serviços atualmente - entre eles John Bateson, Leonard Berry, Stephen Brown, John Czepiel, Pierre Eiglier, William George, Christian Grönroos, Eugene Johnson, Eric Langeard, Christopher Lovelock, Lynn Shostack, Mary Jo Bitner, Valerie Zeithaml e Parasuraman - começaram a escrever e publicar no estágio inicial do desenvolvimento da literatura sobre o assunto, ou seja, na década de 80 (FISK et al., 1994). Esses autores continuam debatendo os principais tópicos da teoria de marketing de serviços, contudo percebeu-se ao longo da revisão bibliográfica desta dissertação que há grande dificuldade de se encontrar consenso sobre conceitos centrais da teoria.

O setor de serviços no Brasil vem crescendo desde a década de 80 segundo dados do Banco Mundial (2007). De acordo com a instituição, o setor de serviços contribuiu em 2005 com $52 \%$ da formação do PIB, número expressivo quando comparado aos outros setores da economia brasileira, porém reduzido ao compará-lo com demais economias do mundo como 
França, Estados Unidos e Reino Unido em que a contribuição do setor de serviços para a formação do PIB é de cerca de $70 \%$. No campo acadêmico, a produção de artigos sobre o marketing de serviços no Brasil ainda é pequena quando comparado aos Estados Unidos e países nórdicos, as duas principais regiões de avanços de conhecimento nessa área (LOURES, 2003).

Um dos principais conceitos do marketing e do marketing de serviços, bastante discutido é seu modelo de gerenciamento. Tradicionalmente o marketing de bens utiliza como ferramenta principal o marketing mix, também chamado de composto de marketing, variáveis de decisão ou variáveis controláveis. Inicialmente o marketing mix foi proposto por Borden (1964), que na verdade sugeriu que o gerenciamento de marketing fosse feito por meio de um conjunto de ferramentas, sem defini-las ou denominá-las. Eugene McCarthy, na década de 70, foi quem propôs o agrupamento das ferramentas em quatro amplos grupos, tal como são conhecidos os 4 P's (Product, Price, Promotion, Place).

No marketing de serviços discute-se se o emprego dessa ferramenta, havendo propostas alternativas para o gerenciamento do marketing de serviços. Tais propostas foram apresentadas para dar corpo à fundamentação teórica, realizando uma ampla discussão sobre o tema. Esta dissertação discute, fundamentalmente, como as variáveis de decisão de marketing são utilizadas em um tipo de serviço desafiador.

Trata-se dos serviços de demanda não desejada, em inglês negative demand conforme definido por Kotler em 1973 como sendo aqueles em que os principais segmentos de mercado não gostam do produto ou até mesmo estão dispostos a pagar um preço para evitá-lo. Para a demanda não desejada os clientes potenciais desenvolvem sentimentos negativos em relação ao produto ofertado. Apesar de pouco estudada no mundo acadêmico, a demanda não desejada está bastante presente no mercado.

Os produtos mais freqüentemente citados como sendo de demanda não desejada são justamente serviços, entre eles de vacinação, médicos, tratamentos dentários, seguros etc. Em certas situações, viagens de trem ou avião têm demanda não desejada, ou ainda, locais para viagem como a Antártida ou desertos comportam-se dessa mesma maneira. O grande desafio do marketing, nesses casos, é mudar o estado da demanda, principalmente quando não há 
problemas de oferta. Para tanto, a empresa toma decisões a respeito de suas variáveis controláveis: produto, preço, distribuição e comunicação.

Propõe-se, assim, estudar, no caso de serviços de demanda não desejada, o gerenciamento das variáveis de decisão de marketing. Espera-se fazer uma abrangente revisão da literatura sobre o tema e confrontar teoria e prática.

\subsection{Justificativa do estudo}

Três justificativas principais podem ser apontadas para a realização deste estudo:

1. Pouca discussão e publicações disponíveis que abordam de maneira aprofundada o marketing de serviços em geral no âmbito da produção acadêmica brasileira.

2. A existência de escassa literatura sobre o gerenciamento do marketing de serviços, especificamente, de demanda não desejada, que poderá dar subsídios para o entendimento de outros tipos de serviços.

3. Finalmente, ser uma fonte de consulta para outros pesquisadores do marketing de serviços, focados no tópico específico de gerenciamento de serviços de demanda não desejada.

\subsection{Problema em estudo}

A partir da discussão apresentada sobre o problema e a justificativa desta dissertação, definiuse o problema em estudo, expresso pela questão a seguir, a qual norteou os esforços da pesquisadora:

Como se dá o gerenciamento das variáveis de decisão de marketing em serviços de demanda não desejada? 


\subsection{Objetivo do estudo}

Esta dissertação tem por objetivo, portanto, estudar o gerenciamento das variáveis de decisão de marketing em serviços de demanda não desejada do ponto de vista conceitual e prático.

\subsection{Organização do texto}

A fim de se atingir o objetivo proposto, respondendo, portanto, a questão do estudo apontada anteriormente, organizou-se esta dissertação em capítulos, sendo que para isso imaginou-se um caminho em forma de funil, ou seja, partindo-se do tema mais amplo para o mais específico, conforme representado na Figura 1 a seguir.

Figura 1 - Organização do raciocínio de discussão.

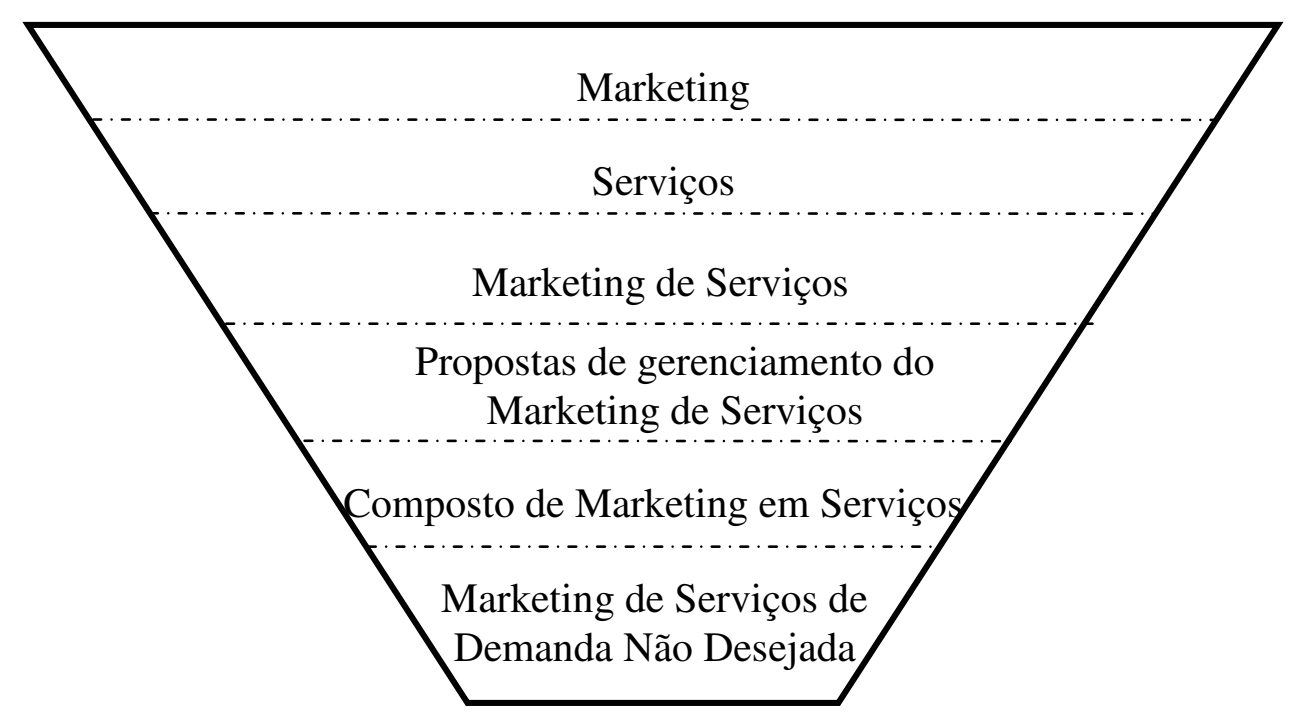

FONTE: elaborado pela autora.

Este capítulo trata da apresentação e justificativa do estudo, definição do objetivo da dissertação e a estratégia de condução do trabalho.

O capítulo 2 apresenta a fundamentação teórica do estudo, englobando a discussão e análise da teoria de marketing de serviços, propostas alternativas para o gerenciamento do marketing de serviços, discussão crítica sobre as variáveis de decisão em serviços e, finalmente a apresentação dos serviços de demanda não desejada. 
No capítulo 3, apresenta-se a descrição da pesquisa de campo. Aborda-se seu o delineamento, destacando-se o tipo de pesquisa, procedimento de coleta de dados, instrumento de coleta e possíveis métodos de análise das informações para atingir os objetivos do estudo.

Segue-se no capítulo 4 com a apresentação individual dos casos escolhidos: Unimed Seguros e MetLife. Faz-se a descrição das fontes de informação consultadas bem como a descrição das sub unidades de análise definidas ao longo do estudo, ou seja, o produto, o preço, a distribuição e a comunicação.

No capítulo 5 analisam-se as informações obtidas nos estudos de caso havendo um entrelaçamento entre conceitos e práticas. O capítulo 6 finaliza o trabalho com as conclusões, limitações do estudo e sugestões para desenvolvimentos futuros. 


\section{FUNDAMENTAÇÃO TEÓRICA}

Neste capítulo busca-se abordar tópicos considerados relevantes para a discussão do tema central desta dissertação, de acordo com a organização de raciocínio apresentada no capítulo anterior, ou seja, partindo-se dos conceitos amplos para os conceitos mais específicos.

Sendo assim, inicia-se com uma breve conceituação do termo "marketing", abordando-se o seu escopo, bem como suas atividades e decisões. Na seqüência, discorre-se sobre o termo "serviços", sua origem, suas principais características e sobre a relevância do estudo do marketing de serviços. Por fim, apresentam-se propostas para o gerenciamento do marketing de serviços, com destaque para o composto de marketing.

Faz-se, ainda, a apresentação e discussão teórica sobre as variáveis de decisão (preço, distribuição, produto e comunicação), finalizando com uma análise crítica dos serviços de demanda não desejada.

Vale aqui pontuar que ao longo da revisão da literatura encontrou-se confusão no emprego dos termos "produto", "serviços" e "bens". Produto, corretamente utilizado, é o termo mais abrangente para serviços ou bens, mas muitas vezes é aplicado como substituto de bens ou até mesmo de serviços. Procurou-se na dissertação utilizar cada um dos termos de maneira correta, sendo que em citações diretas o termo originalmente utilizado foi mantido.

A seguir, dá-se início à revisão da literatura.

\subsection{Marketing}

O termo "marketing" vem sendo amplamente utilizado, sendo que em alguns casos seu exato significado não é empregado de maneira correta. A American Marketing Association (AMA, 2008) define marketing da seguinte forma (traduzido pela autora):

Marketing é uma função organizacional e um conjunto de processos para criação, comunicação, entrega de valor aos consumidores e gerenciamento do relacionamento com o cliente de forma a beneficiar a organização e demais públicos envolvidos. 
A definição mais comumente utilizada, registrada por Kotler e Keller (2005, p.4), considera o marketing como "[...] um processo social por meio do qual pessoas e grupos obtêm o que necessitam e desejam com a criação, oferta e da livre troca de produtos [sic] e serviços de valor com outros". Sendo assim, as atividades de marketing devem considerar as necessidades e desejos do mercado, além do uso efetivo de técnicas de preço, comunicação e distribuição, para informar, motivar e servir ao respectivo mercado. Outras definições poderiam ser transcritas, porém pouco acrescentariam à compreensão do termo.

No entanto, em função da generalidade do conceito, vale descrever alguns temas que são abordados pelo marketing.

\footnotetext{
$\mathrm{O}$ atual escopo do marketing é inquestionavelmente amplo. Normalmente incluem diversas áreas de interesse como comportamento do consumidor, precificação, compras, administração de vendas, administração de produtos, comunicação de marketing, marketing comparativo, marketing social, produtividade e eficiência dos sistemas de marketing, o papel do marketing no desenvolvimento econômico, embalagem, canais de distribuição, pesquisa de marketing, assuntos societais de marketing, varejo, atacadistas, responsabilidade social do marketing, marketing internacional, marketing de commodities e canais de distribuição. Apesar de ampla esta lista de tópicos não esgota todas as possibilidades. (HUNT, 1983, p.9)
}

Tanto não esgota todas as possibilidades que a lista de Hunt (1983) omite, por exemplo, a área de interesse principal deste trabalho: o marketing de serviços.

Campomar (1984), por outro lado, sintetiza as decisões de marketing e suas atividades em cinco grupos:

- Estrutura ou organização de marketing,

- Sistema de informação de marketing,

- Segmentação do mercado,

- Decisões sobre o composto de marketing e

- Planejamento de marketing.

Todas as organizações podem utilizar ou considerar esse grupo de atividades e decisões para o gerenciamento do marketing, desde que as adaptações necessárias ou convenientes sejam feitas, para torná-lo coerente com a realidade presenciada. O foco do presente estudo recai 
sobre uma das decisões de marketing, mais especificamente sobre o composto de marketing também denominado variáveis controláveis ou de decisão -, que será discutido em profundidade ao longo deste capítulo.

A próxima seção apresenta a fundamentação teórica sobre serviços, incluindo discussão sobre as definições do termo, suas principais características, o surgimento do marketing de serviços e sua relevância.

\subsection{Serviços}

\subsubsection{Definições de serviços}

A etimologia da palavra "serviço" é minimamente curiosa. O termo deriva do latim servitium, que tem como significado condição de escravo e obediência. O sentido moderno de serviço é um desdobramento de sua acepção original. Só o dicionário Houaiss da língua portuguesa apresenta mais de vinte definições para o vocábulo (HOUAISS, 2007).

A tentativa de obter uma definição exata, ou convergente, sobre o significado de serviços quando utilizado em administração e, mais especificamente, em marketing foi frustrante no decorrer das leituras de artigos e revistas acadêmicas de renome internacional. Johns (1999) realizou um estudo sobre os múltiplos significados que a palavra pode ter em administração, concluindo que pode se referir: a um setor de atividade econômica; ao resultado de um trabalho ou oferta; e, por fim, do ponto de vista de produção, a um processo. Ainda, segundo a autora, o termo "serviços" em marketing é utilizado de maneira abrangente para designar o resultado de um trabalho ou oferta.

Assim como outros conceitos utilizados na área de marketing, o de serviços também causa divergência de opiniões entre os principais estudiosos desse campo do conhecimento (RATHMELL, 1966; BLOIS, 1974). Em um estudo recente publicado por Vargo e Lusch (2004) argumenta-se que até o momento não existe uma definição sobre serviços que seja amplamente aceita. Os serviços continuam sendo, depois de quase 60 anos de estudos acerca deste subtópico do marketing, aquilo que não é um bem, isto é, aquilo que não pode ser visto, tocado, provado, ouvido e cheirado, conforme a definição de Grönroos (1978), Solomon et al. (1985) e Vargo e Lusch (2004). 
Estudos seminais levam a compreender que a definição da American Marketing Association (AMA) foi a primeira amplamente divulgada (BLOIS, 1974). Tal definição propõe que serviços são "atividades, benefícios ou satisfações que são colocados à venda ou proporcionados de maneira agregada à venda de bens". Blois (1974), autor do primeiro artigo sobre o assunto publicado no European Journal of Marketing, argumenta que a conceituação da AMA também poderia ser indicada a bens, já que podem, igualmente, gerar benefícios e satisfações. Por esse motivo, Blois (1974, p.137) sugere uma versão aprimorada da definição: "Um serviço é uma atividade colocada à venda que gera benefícios e satisfações, sem levar a uma mudança física na forma de um bem."

Nota-se que na etapa inicial do desenvolvimento da literatura sobre serviços, acadêmicos utilizaram os bens como apoio à definição do termo. Percebe-se também que entendiam os serviços como algo que poderia ser agregado à oferta de bens e, ainda, como uma atividade.

As publicações de Grönroos (2003), Kotler e Keller (2005), Fitzsimmons e Fitzsimmons (2005) e Lovelock e Wirtz (2006) apresentam definições mais recentes de serviços. Grönroos (2003, p.65) apresenta a seguinte acepção:

\footnotetext{
Um serviço é um processo, consistindo em uma série de atividades mais ou menos intangíveis que, normalmente, mas não necessariamente sempre, ocorrem nas interações entre o cliente e os funcionários de serviços e/ou recursos ou bens físicos e/ou sistemas do fornecedor de serviços e que são fornecidas como soluções para problemas do cliente.
}

Kotler e Keller (2005, p.397) apresentam definição semelhante àquela anteriormente registrada no livro de Kotler e Bloom sobre serviços profissionais (1984), atribuindo ao termo serviços o seguinte significado: “[...] qualquer ato ou desempenho, essencialmente intangível, que uma parte pode oferecer a outra e que não resulta na propriedade de nada. A execução de um serviço pode estar ou não ligada a um produto concreto.” Fitzsimmons e Fitzsimmons (2005), por sua vez, definem serviços como “[...] uma experiência perecível, intangível, desenvolvida para um consumidor que desempenha o papel de co-produtor". Finalmente, Lovelock e Wirtz (2006, p.8) sugerem duas definições que, segundo eles, capturam a essência dos serviços: 
Um serviço é um ato ou desempenho oferecido por uma parte à outra. Embora o processo possa estar vinculado a um produto físico (sic), o desempenho é transitório, freqüentemente de natureza intangível e não resulta normalmente em propriedade de quaisquer dos fatores de produção.

Um serviço é uma atividade econômica que cria valor e proporciona benefícios a clientes em horários e locais específicos, efetuando uma mudança desejada em quem recebe o serviço, ou em seu nome.

Essas conceituações publicadas recentemente definem, portanto, os serviços como processos ou desempenhos. Já Fitzsimmons e Fitzsimmons (2005) dão um passo adiante, definindo serviço do ponto de vista do consumidor, considerando-o, dessa forma, uma experiência. Todas essas concepções recentes preocupam-se em destacar uma das características dos serviços: a intangibilidade. Também se dá destaque à questão da interação do consumidor com o prestador de serviços (sistemas ou funcionários), que enfatiza a condição participativa do cliente no processo de prestação de serviços.

Ainda que não tenha sido encontrada uma definição aceita amplamente pelos principais estudiosos do assunto, foi possível, por meio da análise de diversas definições, obter uma idéia sobre o que significa a oferta de um serviço ou pelo menos sobre o que faz este setor de atividade econômica. Sendo assim, verifica-se que os serviços, assim como os bens, devem ser oferecidos por uma parte a outra e satisfazer a necessidade daquele que compra. Constatase, ainda, que o serviço pode ser uma atividade, um desempenho ou um processo, mas é essencialmente uma experiência que resulta na posse de nada, só da própria experiência, que deve proporcionar benefícios ao consumidor.

Isso posto, pode-se dissertar sobre a importância do estudo do marketing de serviços, assunto que será abordado na próxima seção.

\subsubsection{O marketing de serviços e sua importância}

O principal foco de estudo do marketing no início do século passado eram os produtos provenientes de atividades agrícolas. Poucos anos depois, o foco passou a ser os produtos industrializados, ou seja, os bens, que são a essência dos principais fundamentos de marketing que se conhece até hoje. Aos serviços pouca importância era dada. 
Apenas a partir do final da década 60 e início dos anos 70 os estudos na área de marketing com foco em serviços começaram a se desenvolver. Isso porque o setor de serviços na economia dos países desenvolvidos, principalmente nos Estados Unidos, começou a ter importância a partir da década de 40 (FISK et al., 1993).

O marketing de serviços - ou services marketing, termo em inglês - é a área de conhecimento que estuda o marketing para a venda de serviços (AMA, 2007). Mais do que simplesmente isso, o marketing de serviços estuda o que não transfere posse.

Conforme destacam Lovelock e Wirtz (2006) em estudo sobre os setores econômicos e sua classificação, as atividades de serviços constituem a maior parte da economia, principalmente nos países desenvolvidos, sendo crescente o aumento de sua participação nos mais diversos sistemas produtivos. A Tabela 1 apresenta dados divulgados pelo Banco Mundial sobre a participação dos setores de atividade econômica no Produto Interno Bruto (PIB) de alguns países selecionados para essa análise. Nota-se que em países de primeiro mundo, como Estados Unidos, França e Reino Unido, o setor de serviços contribui com cerca de $75 \%$ para a formação do PIB, seguido do setor industrial, cuja contribuição gira em torno de 25\%, enquanto a agricultura tem participação quase insignificante na economia desses países. Desde a década de 80 até os dias de hoje percebe-se a forte tendência de crescimento do setor de serviços e de queda dos outros dois setores de atividade econômica.

O México, caso particular de país subdesenvolvido por manter fortes relações comerciais com os Estados Unidos, conta com um setor de serviços bastante desenvolvido e que cresceu de maneira significativa da década de 1980 até 2005, passando sua participação no PIB do país de 56,3\% para 70,2\%. Já a Argentina, país sul-americano freqüentemente comparado com o Brasil, apresenta dados bastante parecidos com os dados brasileiros, contando com um setor agrícola que contribui com cerca de $10 \%$ para a formação do PIB, um setor industrial forte e importante, mas com pequena diminuição participativa nas últimas décadas, e um setor de serviços crescente, responsável por mais de 50\% do PIB do país. Por fim, os dados da China, país em franco desenvolvimento, mostram que nos últimos anos o setor agricultor diminuiu, o da indústria permaneceu estável e o de serviços apresentou forte crescimento. 
Tabela 1 - Percentual de participação dos setores de atividade econômica no PIB.

\begin{tabular}{|c|c|c|c|c|c|c|c|c|c|c|c|c|c|c|c|c|c|c|}
\hline \multirow[b]{2}{*}{ Países } & \multicolumn{6}{|c|}{ Agricultura } & \multicolumn{6}{|c|}{ Indústria } & \multicolumn{6}{|c|}{ Serviços } \\
\hline & 1983 & 1993 & 2002 & 2003 & 2004 & 2005 & 1983 & 1993 & 2002 & 2003 & 2004 & 2005 & 1983 & 1993 & 2002 & 2003 & 2004 & 2005 \\
\hline Estados Unidos & 2,2 & 1,9 & 1 & 1,2 & .. &.. & 31,6 & 25,7 & 22,2 & 22,3 & .. &.. & 66,3 & 72,4 & 76,7 & 76,5 & , & .. \\
\hline França & 4,7 & 3,1 & 2,7 & 2,6 & 2,5 & .. & 33,5 & 27,5 & 21,8 & 21,5 & 21,7 & .. & 61,8 & 69,4 & 75,5 & 75,9 & 75,8 & \\
\hline Reino Unido & 2 & 1,8 & 1 & 1 & 1 & .. & 40,9 & 31,3 & 26,1 & 26,2 & 26,3 & & 57,1 & 66,9 & 72,9 & 72,8 & 72,7 & .. \\
\hline México & 8,5 & 6,3 & 3,9 & 3,9 & 3,9 & 3,8 & 35,2 & 26,8 & 26,5 & 25,8 & 26,3 & 25,9 & 56,3 & 66,9 & 69,6 & 70,3 & 69,8 & 70,2 \\
\hline Argentina & 8,7 & 5,5 & 10,8 & 11 & 10,4 & .. & 41,6 & 29,2 & 32,4 & 34,7 & 35,6 & & 49,8 & 65,3 & 56,8 & 54,3 & 54 & \\
\hline Brasil & 10,9 & 7,6 & 8,7 & 10,2 & 10,4 & 9,8 & 44 & 41,6 & 38 & 39,9 & 40 & 37,9 & 45,1 & 50,8 & 53,3 & 50 & 49,6 & 52,3 \\
\hline China & 33 & 19,9 & 13,5 & 12,6 & 13,1 & .. & 44,6 & 47,4 & 44,8 & 46 & 46,2 &.. & 22,4 & 32,7 & 41,7 & 41,5 & 40,7 & .. \\
\hline
\end{tabular}

FONTE: BANCO MUNDIAL, 2007.

No que se refere ao Brasil, de acordo com o censo realizado pelo Instituto Brasileiro de Geografia e Estatística (IBGE) no ano de 2000, dos mais de 65 milhões de brasileiros economicamente ativos, aproximadamente $55 \%$ trabalham no setor de serviços, sendo que os outros $45 \%$ se dividem entre a agricultura (18\%), a indústria (19\%) e outras atividades não especificadas (8\%). O Gráfico 1 mostra em destaque a evolução de cada um dos setores da economia brasileira.

Gráfico 1 - Evolução da participação dos setores da economia brasileira no PIB.

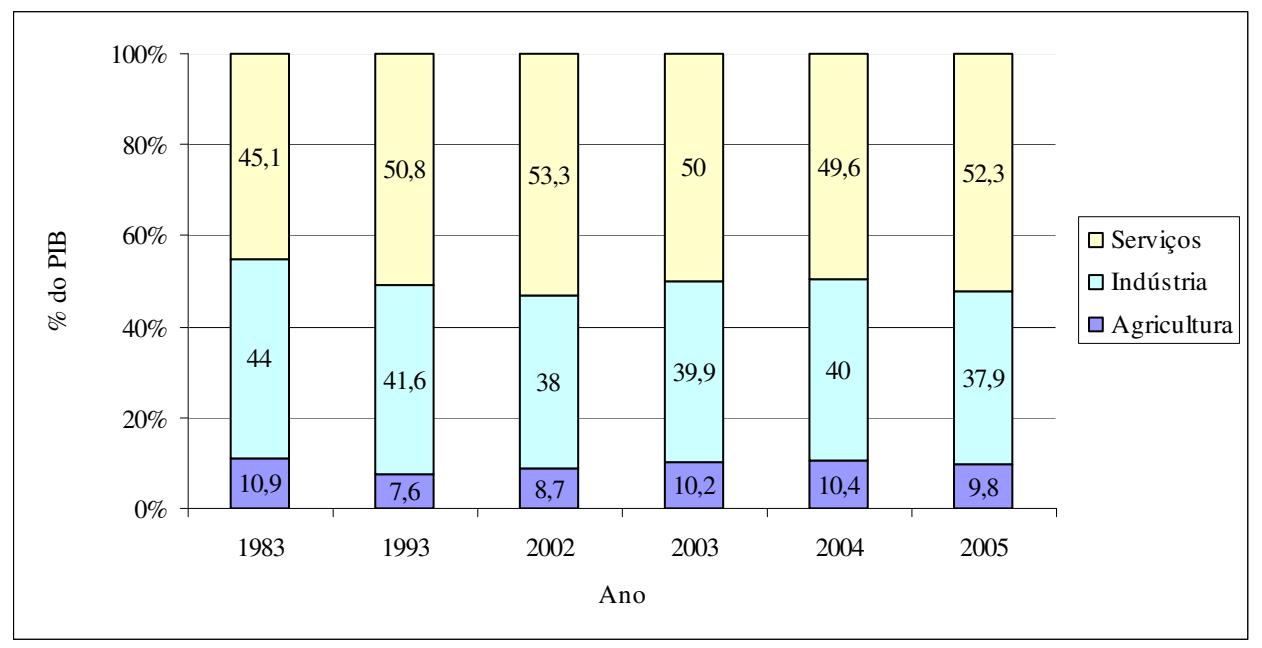

FONTE: IBGE, 2007.

A análise anterior ajuda a compreender a relevância do setor de serviços na economia mundial e sua tendência de crescimento, bem como sua proeminência como maior empregador, o que justifica o estudo do marketing de serviços e sua importância no âmbito acadêmico. Boone e Kurtz (2006) enfatizam que o crescimento potencial das transações em serviços representa uma grande oportunidade para os estudiosos. Ademais, esse crescimento aumenta a competição e sinaliza a necessidade de ferramentas de marketing melhor desenvolvidas. 
Destarte, pode-se afirmar que tais fatores já ratificam a importância de se estudar o marketing de serviços, mas o esquadrinhamento do assunto torna-se ainda mais imperioso considerandose os dados divulgados pelo PROCON (Fundação de Proteção e Defesa do Consumidor), órgão de defesa e proteção do consumidor fundado há mais de trinta anos. Segundo a referida Fundação, o setor de serviços foi o que gerou mais reclamações em 2006 e 2007. As empresas recordistas em reclamações são do setor de serviços, principalmente do mercado de telecomunicações. São elas:

Tabela 2 - Ranking das empresas com maior número de reclamações em 2006 e 2007.

\begin{tabular}{|c|c|c|}
\hline Posição & $\mathbf{2 0 0 6}$ & $\mathbf{2 0 0 7}$ \\
\hline $\mathbf{1}^{\mathbf{a}}$ & Telefônica & Telefônica \\
\hline $\mathbf{2}^{\mathbf{a}}$ & Vivo & Itaú \\
\hline $\mathbf{3}^{\mathbf{a}}$ & Embratel & Benq \\
\hline $\mathbf{4}^{\mathbf{a}}$ & Parque Aquático do Gugu & Vivo \\
\hline $\mathbf{5}^{\mathbf{a}}$ & Claro & Mitsubishi \\
\hline
\end{tabular}

FONTE: PROCON, 2008.

Em 2007 o PROCON registrou mais de 500 mil atendimentos. A seguir, pode-se verificar o percentual de queixas de cada área de atendimento da Fundação:

Gráfico 2 - Atendimentos por área realizados pelo PROCON.

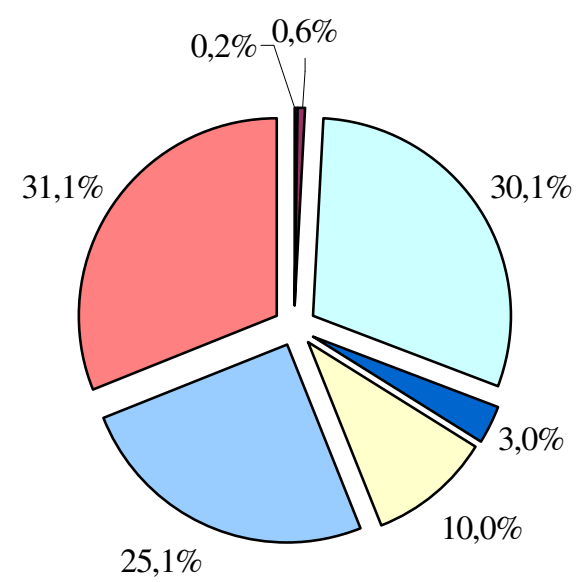

$\square$ Alimentos

$\square$ Habitação

$\square$ Produtos

$\square$ Saúde

$\square$ Serviços Privados

$\square$ Assuntos Financeiros

$\square$ Serviços Essenciais

FONTE: PROCON, 2008. 
As áreas de atendimento são descritas pelo PROCON da seguinte maneira:

- Alimentos: problemas com alguma característica do alimento;

- Habitação: compra de lote, condomínio, imóvel, locação;

- Produtos: problemas relativos ao funcionamento dos produtos;

- Saúde: animais de estimação, clínicas de estética, controle de pragas, cosméticos, medicamentos, planos de saúde, preservativos;

- Serviços Privados: clubes, cursos livres, escolas particulares, Internet, prestação de serviços, turismo;

- Assuntos Financeiros: banco, cartão de crédito, consórcios, empréstimos, leasing, seguros, taxas de juros e títulos de capitalização;

- Serviços Essenciais: água e esgoto, energia elétrica, telefonia fixa, telefonia móvel.

Somando-se as áreas que o próprio PROCON define como serviços - Serviços Essenciais e Serviços Privados -, o percentual de reclamações deste campo de atividade econômica seria de aproximadamente 50\%. No entanto, ainda é possível somar as reclamações de outras áreas, tais como Saúde, Assuntos Financeiros e Habitação, que também são serviços, o que reforça que a maior parte das reclamações realizadas na Fundação refere-se ao setor de serviços. Os dados do PROCON sugerem que o setor, a despeito de seu destaque na economia, tem necessidade de ser estudado e desenvolvido do ponto de vista do consumidor e, portanto, do marketing.

Outro fator que torna o estudo do marketing de serviços relevante é que ele pode ser entendido também como uma crítica às teorias de marketing, que quando desenvolvidas tenderam a basear-se mais em especulação, e quando verificadas empiricamente foram, de acordo com McLean (1994), conduzidas:

- Sob a óptica da cultura norte-americana;

- Em grandes corporações, ao invés de em pequenas;

- Considerando a venda de bens, e não de serviços;

- Admitindo organizações com fins lucrativos, e não sem fins lucrativos;

- Contemplando mercados homogêneos, ao invés de heterogêneos; e

- Levando em conta o setor privado, e não o público. 
Para Lovelock e Gummensson (2004), um novo campo de estudo, como esse, pode ser analisado não só por meio da revisão da literatura sobre o assunto, mas também mediante pesquisas empíricas ou, ainda, reanálises acerca do extenso conhecimento disponível e não utilizado.

Para dar início à discussão sobre o gerenciamento de serviços, a próxima seção irá abordar um tema amplamente estudado e discutido na fase embrionária do marketing de serviços: as características diferenciadoras entre serviços e bens. Pretende-se, ainda, revisar a literatura sobre a fase embrionária do marketing de serviços, promovendo também uma reanálise do conhecimento disponível.

\subsubsection{Características dos serviços}

Alguns estudiosos consideram o marketing de serviços diferente do marketing de bens, devido às características distintas dos serviços, tais como intangibilidade, variabilidade, heterogeneidade e perecibilidade. O Quadro 1 apresenta um resumo dos principais autores que abordam o assunto e das características que defendem como diferenciadoras, evidenciando que a distinção entre serviços e bens já foi longamente discutida na literatura. No entanto, vale ressaltar que não se pretende defender um ponto de vista sobre as diferenças indicadas no referido quadro, mas sim apresentar as principais perspectivas sobre o tema, já que podem influenciar análises posteriores deste trabalho.

Em função de tais características diferenciadoras, estudiosos passaram a propor uma nova abordagem para o marketing de serviços. As distinções foram propostas na fase embrionária do marketing de serviços - período assim definido por Fisk et al. (1993) - e bastante discutidas pelos principais estudiosos do assunto (John Bateson, Leonard Berry, Stephen Brown, Christian Grönroos, Christopher Lovelock, Lynn Shostack, entre outros) até o final dos anos 1980, verificando-se certo desacordo entre os autores (ARAÚJO, GORGULHO, 2002). 
Quadro 1 - Principais publicações acadêmicas que abordam as características diferenciadoras dos serviços.

\begin{tabular}{|c|c|c|c|c|}
\hline \multirow[b]{2}{*}{ Publicações } & \multicolumn{4}{|c|}{ Características } \\
\hline & Intangibilidade & Variabilidade & Inseparabilidade & Perecibilidade \\
\hline Bateson $(1977,1979)$ & $\mathrm{x}$ & & $\mathrm{x}$ & $\mathrm{x}$ \\
\hline Bell (1981) & $\mathrm{x}$ & $\mathrm{x}$ & & $\mathrm{x}$ \\
\hline Berry $(1975,1980,1983)$ & $\mathrm{x}$ & $\mathrm{x}$ & $\mathrm{x}$ & $\mathrm{x}$ \\
\hline Bessom e Jackson (1975) & $\mathrm{x}$ & $\mathrm{x}$ & $\mathrm{x}$ & \\
\hline Booms e Bitner $(1981,1982)$ & $\mathrm{x}$ & & $\mathrm{x}$ & \\
\hline Carmne e Langeard (1980) & $\mathrm{x}$ & $\mathrm{x}$ & $\mathrm{x}$ & \\
\hline Davidson (1978) & $\mathrm{x}$ & $\mathrm{x}$ & $\mathrm{x}$ & \\
\hline Davis, Guiltinan e Jones (1979) & $\mathrm{x}$ & & $\mathrm{x}$ & \\
\hline Donnelly $(1976,1980)$ & $\mathrm{x}$ & & $\mathrm{x}$ & $\mathrm{x}$ \\
\hline Eiglier e Langeard $(1975,1976)$, Eiglier et al. (1977) & $\mathrm{x}$ & $\mathrm{x}$ & $\mathrm{x}$ & \\
\hline Fisk (1981) & $\mathrm{x}$ & & & \\
\hline George e Barksdale (1974), George (1977) & $\mathrm{x}$ & & $\mathrm{x}$ & \\
\hline Grönroos $(1977,1978,1979,1983$ & $\mathrm{x}$ & & $\mathrm{x}$ & \\
\hline Johnson $(1969,1981)$ & $\mathrm{x}$ & $\mathrm{x}$ & $\mathrm{x}$ & \\
\hline Judd (1968) & $\mathrm{x}$ & & $\mathrm{x}$ & \\
\hline Knisely (1979a, 1979b, 1979c) & $\mathrm{x}$ & $\mathrm{x}$ & $\mathrm{x}$ & $\mathrm{x}$ \\
\hline Langeard et al. (1981) & $\mathrm{x}$ & $\mathrm{x}$ & $\mathrm{x}$ & \\
\hline Lovelock e Lovelock et al. (1981) & $\mathrm{x}$ & & $\mathrm{x}$ & \\
\hline Rathmell $(1966,1974)$ & & $\mathrm{x}$ & $\mathrm{x}$ & $\mathrm{x}$ \\
\hline Regan (1963) & $\mathrm{x}$ & $\mathrm{x}$ & $\mathrm{x}$ & $\mathrm{x}$ \\
\hline Sasser (1976), Sasser e Arbeit (1978) & $\mathrm{x}$ & $\mathrm{x}$ & $\mathrm{x}$ & $\mathrm{x}$ \\
\hline Schlissel (1977) & $\mathrm{x}$ & $\mathrm{x}$ & $\mathrm{x}$ & \\
\hline Shostack (1977a, 1977b) & $\mathrm{x}$ & $\mathrm{x}$ & $\mathrm{x}$ & \\
\hline Thomas (1978) & $\mathrm{x}$ & $\mathrm{x}$ & & $\mathrm{x}$ \\
\hline Uhl e Upah (1980), Upah (1980), Upah e Uhl (1981) & $\mathrm{x}$ & $\mathrm{x}$ & $\mathrm{x}$ & $\mathrm{x}$ \\
\hline Zeithaml (1981) & $\mathrm{x}$ & $\mathrm{x}$ & $\mathrm{x}$ & \\
\hline
\end{tabular}

FONTE: Adaptado de ZEITHAML et al., 1985.

Gummesson (2005, p.121) afirma que “[...] a distinção entre bens e serviços ser tornou um fardo". Outros autores (SCHLESINGER, HESKETT, 1991; NORMANN, RAMIREZ, 1993; GRÖNROOS, 1994; GUMMESSON, 2005; VARGO, LUSCH, 2004) argumentam que o marketing de serviços e o de bens devem convergir, predominando a orientação para serviços.

A seguir apresenta-se cada uma das características diferenciadoras.

\subsubsection{Intangibilidade}

A intangibilidade é a característica diferenciadora universalmente aceita (ZEITHAML et al., 1985) pelos principais estudiosos do marketing de serviços, conforme já se pôde observar no quadro anteriormente apresentado. Sem dúvida, é a característica mais óbvia dos serviços. 
De acordo com Grönroos (1978), a intangibilidade é uma das características mais vitais para o planejamento do marketing de serviços e refere-se ao fato de os serviços não poderem ser percebidos pelos cinco sentidos humanos. O ponto importante nessa questão é que, como os serviços são intangíveis, ou seja, são processos e performances, e não objetos (ZEITHAML et al., 1985), os consumidores avaliam aquilo que podem, ou seja, elementos físicos que estão envolvidos no processo de prestação de serviços, como as instalações físicas de um consultório médico, a aparência dos funcionários de um hotel e o comportamento de outros consumidores. (WYCKHAM et al., 1975; GRÖNROOS, 1978) Assim, Grönroos (1978) sugere que isso seja trabalhado pela empresa, para que os serviços possam se transformar em ofertas concretas na mente do consumidor e para que este possa fazer comparações com a concorrência.

No mesmo sentido, Lovelock e Wirtz (2006, p.10) afirmam: “[...] na ausência de elementos tangíveis significativos, profissionais de marketing poderão achar útil empregar imagens físicas e metáforas para demonstrar as competências da empresa de serviços e ilustrar os benefícios resultantes da entrega do serviço."

\subsubsection{Inseparabilidade}

A simultaneidade entre a produção e o consumo dos serviços é uma importante diferença destes em relação aos bens, conforme argumenta Grönroos (2000), que atribui aos serviços uma maior dificuldade de gerenciamento. Diferentemente dos bens, os serviços são primeiro vendidos, depois produzidos e consumidos, sendo que a presença e a participação do consumidor no momento da produção dos serviços se fazem necessárias (REGAN, 1963). Wyckham et al. (1975) argumentam que a inseparabilidade limita o tamanho do mercado que uma empresa pode atender.

Essa característica diferenciadora requer que o marketing e a área de produção das empresas trabalhem com maior proximidade. Além disso, Grönroos (1978) aponta que a distribuição dos serviços deve ser direta - da empresa para o consumidor final. 


\subsubsection{Variabilidade}

A variabilidade, de acordo com Vargo e Lusch (2004), refere-se à incapacidade de se padronizar o resultado de um serviço prestado. A intangibilidade somada à inseparabilidade, tendo em vista a presença quase que constante da interação humana no processo de prestação de serviços, dão origem à variabilidade. Assim como a característica de intangibilidade, a variabilidade também se baseia em um ponto de vista manufatureiro, de produção (WYCKHAM et al., 1975). Todavia, Wyckham et al. (1975) criticam a diferenciação entre os serviços e os bens nesse aspecto, pois, segundo eles, mesmo os bens, que são fabricados uniformemente pelas empresas, podem ser percebidos de maneiras distintas pelos consumidores.

Para Grönroos (2003), essa característica cria um dos maiores problemas para o marketing de serviços, que é o gerenciamento da qualidade. Esta, conforme o autor, deveria ser uniformemente percebida pelos consumidores. O principal motivo para a heterogeneidade, segundo ele, são as interações sociais que ocorrem no processo de produção do serviço, que variam de indivíduo para indivíduo.

\subsubsection{Perecibilidade}

De acordo com Lovelock e Wirtz (2006), os serviços são efêmeros, ou seja, não transitórios e não podem ser estocados. Quartos de hotéis não ocupados, acentos de aeronaves não vendidos e a capacidade da linha telefônica, por exemplo, não podem ser reclamados se não forem utilizados no momento em que disponibilizados pela empresa. A perecibilidade pode ser acompanhada de demanda flutuante, levando à subutilização (McLEAN, 1994) de outros elementos necessários para a prestação de serviços que podem ser estocados, como instalações e equipamentos. Esses elementos, no entanto, somente viabilizam a prestação do serviço principal. Sendo assim, Lovelock e Wirtz (2006) sugerem que os profissionais de marketing devem se preocupar em ajustar a demanda com a oferta, a fim de buscar um encaixe perfeito entre ambos, garantindo assim um bom relacionamento com o consumidor.

Resumidamente, Zeithaml et al. (1985) apontam os seguintes problemas resultantes da característica de perecibilidade dos serviços: 
- Não podem ser estocados;

- Não podem ser protegidos por patentes;

- A oferta e comunicação não podem ser prontamente feitas;

- A definição de preços é difícil.

$* * * * *$

Apresentar as características diferenciadoras entre bens e serviços é importante porque muitas das discussões em marketing de serviços são balizadas por elas. Entretanto, não se pretendeu julgar se essas são de fato características diferenciadoras entre bens e serviços. De qualquer forma, são consideradas importantes para este estudo, a despeito dessa discussão, já que, se não são diferenciadoras, são ao menos características indiscutíveis dos serviços e relevantes para seu gerenciamento.

Dando continuidade ao embasamento teórico, a seção seguinte aborda os principais modelos de gerenciamento de marketing de serviços encontrados na teoria disponível sobre o assunto.

\subsection{Propostas de gerenciamento do marketing de serviços}

Ter-se-ia uma visão míope do gerenciamento do marketing de serviços se apenas o composto de marketing fosse discutido como ferramenta de gerenciamento. Por esse motivo, decidiu-se abordar outras propostas, a fim de se fazer uma análise crítica de cada uma delas em contraposição à proposição tradicional do composto de marketing. Nesse sentido, serão apresentadas a seguir as propostas de Shostack (1977), Grönroos $(1978 ; 1982)$ e Beaven e Scotti (1990) e, por fim, abordar-se-á a proposta do composto de marketing expandido.

\subsubsection{Modelo Molecular de Shostack (1977)}

Shostack (1977) é uma das autoras de marketing de serviços que critica a utilização do marketing mix para o gerenciamento de serviços, argumentando que essa é uma ferramenta concebida a partir de conceitos manufatureiros, na lógica dos bens tangíveis. Shostack (1977) analisa sob uma nova óptica a oferta do que comumente se denomina bens e serviços, e prefere entender as ofertas como sendo compostas por elementos mais ou menos tangíveis. Segundo ela, as ações de marketing irão variar de acordo com a predominância de elementos tangíveis ou intangíveis. 
Em seu artigo, Shostack (1977) não admite o marketing dicotômico para bens ou serviço, acreditando que esse não seria o caminho para o desenvolvimento de uma teoria de marketing que apoiaria as decisões em uma empresa. Por isso propõe o Modelo Molecular, que tem como objetivo primordial proporcionar o entendimento do núcleo central da oferta de determinada empresa - na visão ortodoxa esse é o $\mathrm{P}$ de produto - e a partir daí aplicar o composto de ferramentas decisórias do marketing, ou seja, os 4 P's.

Segundo a autora, o serviço, mesmo sendo intangível, compreende aspectos tangíveis ou mesmo bens agregados à sua oferta. Por isso Shostack (1977) postula que o produto, elemento central do composto de marketing, é uma combinação de elementos de serviço e de bens. Foi Shostack (1977) que pela primeira vez apresentou a escala de elementos tangíveis e intangíveis na oferta de um produto.

Nesse sentido, a Figura 2 apresenta o sal como sendo um produto predominantemente constituído de elementos tangíveis e uma aula lecionada por um professor como sendo um produto predominantemente constituído de elementos intangíveis, havendo uma variedade de outros tipos de ofertas entre esses dois extremos.

Figura 2 - Predominância de elementos tangíveis e intangíveis na oferta de produtos.

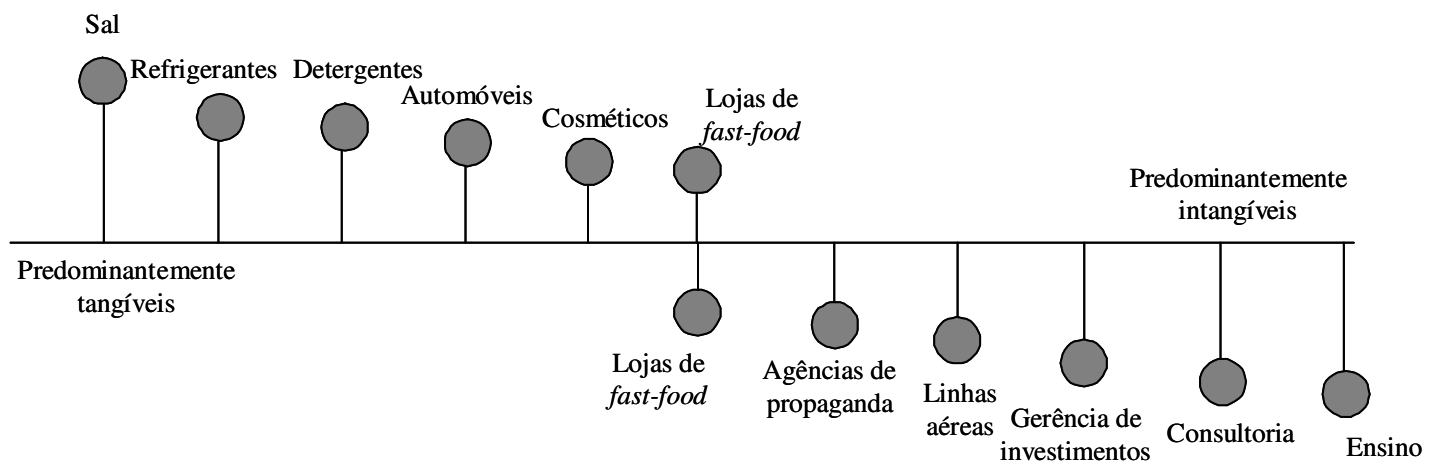

FONTE: SHOSTACK, 1977, p.77.

Shostack (1977) exemplifica o Modelo Molecular comparando a indústria automobilística e a de aviação, como mostrado na Figura 3. Ambas comercializam transporte, mas o produto da indústria de aviação é predominantemente intangível, enquanto o produto da empresa de automóveis é predominantemente tangível. Para definir o grau de predominância dos 
elementos tangíveis ou intangíveis é mais importante o tamanho dos elementos do que o número de elementos. Na Figura 3 podem-se constatar as diferenças de tamanho de cada um dos elementos que compõem os produtos.

Figura 3 - Diagrama do Modelo Molecular.
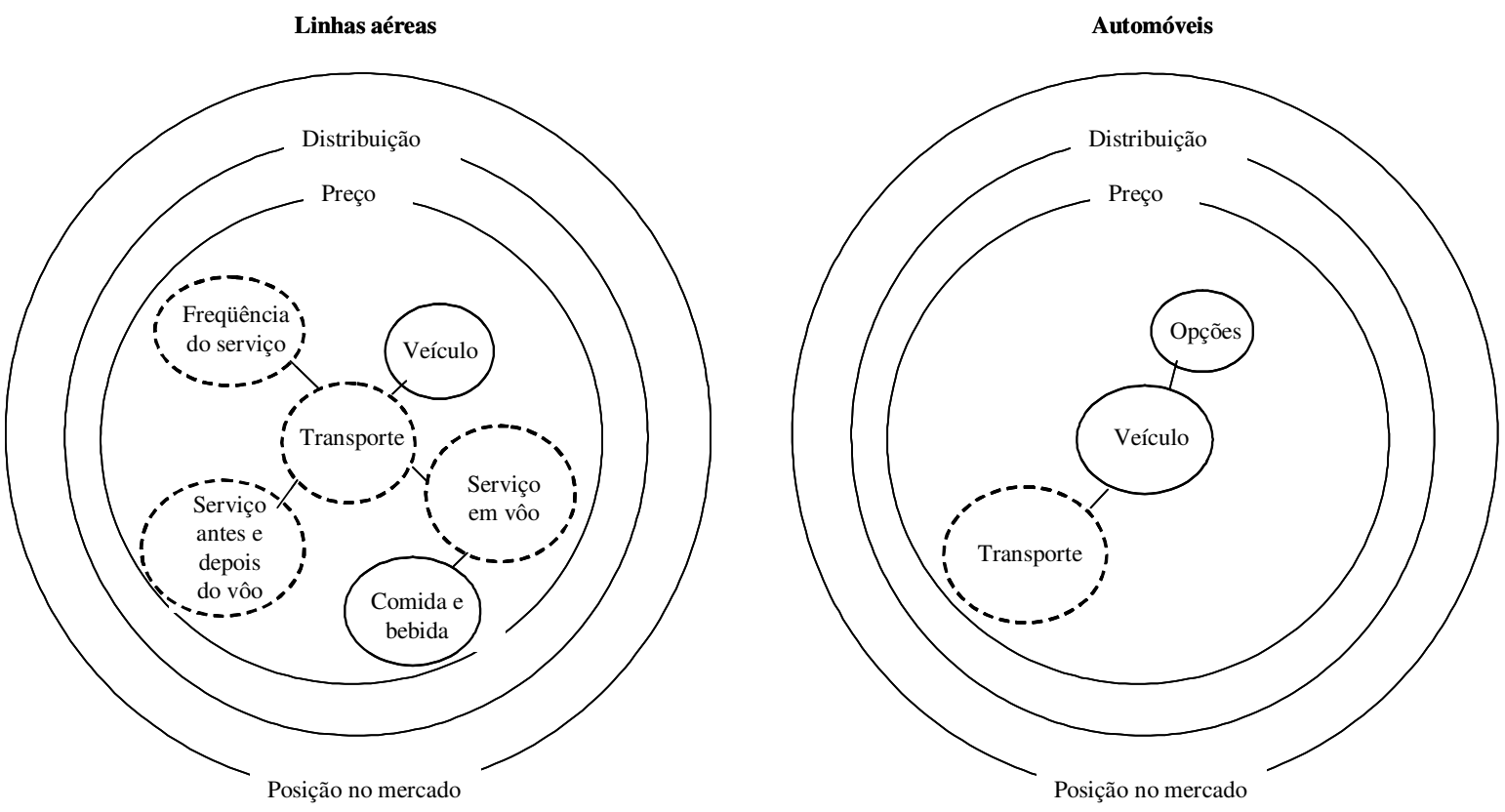

FONTE: SHOSTACK, 1977, p.76.

Sobre esse modelo proposto por Shostack (1977), pode-se dizer que é bastante criativo, conforme sustenta a própria autora. Trata-se de uma abordagem interessante para o gerenciamento de ofertas ao consumidor, já que revoluciona o marketing dicotômico bensserviço. Por esse motivo, pode-se afirmar que poderia, ao longo dos últimos 40 anos, ter ganhado sustentação e, principalmente, aceitação entre profissionais de marketing e acadêmicos. No entanto, a proposta de Shostack não evoluiu ao longo do tempo, apenas apontou uma nova maneira para interpretar a realidade, promovendo uma discussão sobre o P de produto. Carece, portanto, de mais discussões sobre as demais variáveis de decisão, que certamente podem ser decididas a partir das informações sobre a composição do produto central.

\subsubsection{Modelo de Grönroos (1978; 1982)}

A motivação de Grönroos (1978) para a proposição de um modelo de gerenciamento de marketing de serviços, de acordo com o próprio autor, foi a constatação, por meio de pesquisas com empresas prestadoras de serviços, de que não havia teoria de marketing que 
pudesse dar apoio real à difícil tarefa do gerenciamento de marketing de serviços. Grönroos (1978), assim como Shostack (1977), também acredita que o composta de marketing foi desenvolvido sob a óptica de marketing de bens. A crítica principal do autor refere-se à falta de um núcleo central tangível por meio do qual as demais variáveis de decisão pudessem ser planejadas.

Para formular essa proposta, Grönroos (1978) realizou doze estudos de casos de planejamento de marketing em empresas de sucesso da Suécia e da Finlândia de diferentes indústrias de serviço. O autor, em seu estudo, argumenta estar fazendo um teste de hipótese, mas, na verdade, o que realizou foi uma pesquisa mediante questionários e, posteriormente, entrevistas individuais, para verificar as dificuldades relacionadas à administração do marketing de serviços.

A proposta de Grönroos (1978) divide-se em duas partes, os elementos intracorporativos e os extracorporativos, ambos conduzidos sob o ponto de vista do consumidor, conforme mostra a Figura 4. Os elementos intracorporativos são três: acessibilidade, comunicação pessoal e serviços auxiliares, e nada mais são que variáveis controláveis ou de decisão. Já os elementos extracorporativos são aqueles advindos das crenças, desejos e necessidades do consumidor, e talvez possam ser entendidos como variáveis incontroláveis.

Figura 4 - Uma visão extensiva do serviço.

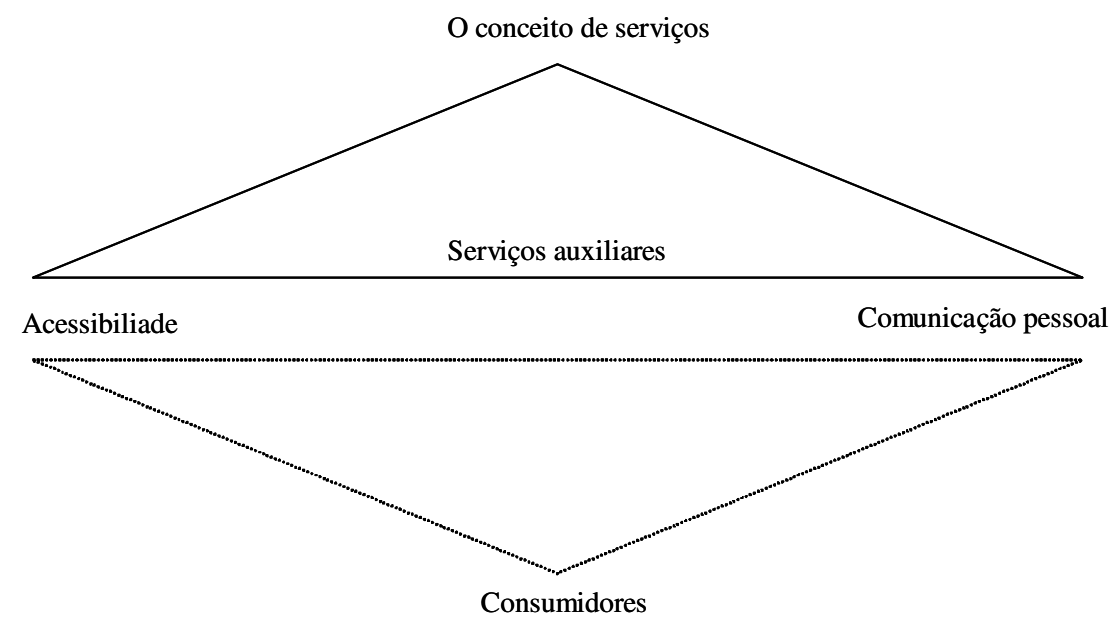

FONTE: GRÖNROOS, 1978, p.597. 
O conceito de acessibilidade dos serviços, um dos elementos intracorporativos, pode ser considerado uma releitura do conceito tradicional de distribuição. Grönroos (1978) acredita que o conceito de acessibilidade é muito mais adequado ao marketing de serviços do que a distribuição, alegando que permite ao marketing de serviços se livrar do fardo constituído pelo conceito tradicional de distribuição.

Anteriormente à publicação de Grönroos (1978), a distribuição direta era mencionada como a única forma de tornar um serviço acessível aos consumidores, dada sua característica de inseparabilidade. No entanto, tanto recursos humanos (funcionários) quanto não humanos (máquinas, escritórios) e mesmo serviços complementares influenciam a acessibilidade do serviço, possibilitando que seja transformado em uma oferta concreta ao consumidor. Destarte, podem ser gerenciados e tornar-se fonte de vantagem competitiva em relação à concorrência.

O segundo elemento intracorporativo, a comunicação pessoal, é de suma importância em serviços, de acordo com Grönroos (1978), posto que o consumidor de um serviço quase sempre se encontra com algum representante da empresa de serviço durante a compra e/ou processo de consumo. Sendo assim, quase todos os funcionários de uma empresa de serviço agem como vendedores envolvidos nos esforços de comunicação de mercado. Ao mesmo tempo em que os recursos humanos da empresa ofertante de serviços é um dos elementos da comunicação pessoal, são também parte do sistema de acessibilidade do serviço, fato que faz com que as pessoas sejam importantes para a companhia e seu planejamento.

O treinamento dos profissionais da empresa de serviços em relação a questões de marketing, ou seja, abrangendo situações relacionadas à venda e ao atendimento ao consumidor, entre outros elementos, é mais importante na indústria de serviços que na de bens. A atitude das pessoas de uma empresa de serviços deve, portanto, ser alterada, de maneira que os empregados aceitem que não são apenas produtores de um serviço e engajem-se também em sua venda.

O terceiro e último elemento intracorporativo, os serviços auxiliares, influencia diretamente a acessibilidade de um serviço. Às vezes um mesmo serviço auxiliar pode significar maior acessibilidade para um consumidor, enquanto para outro pode ser apenas um serviço auxiliar. Nessa perspectiva, um serviço auxiliar não é apenas um suporte para levar o serviço ao 
mercado, uma vez que pode ser uma ferramenta de promoção, de diferencial competitivo, e ser considerado parte do serviço principal pelos consumidores. Como exemplos de serviços auxiliares podem-se citar a disponibilização de um estacionamento para a clientela, o oferecimento de um cafezinho enquanto o cliente aguarda o atendimento, a entrega em domicílio etc.

Para Grönroos (1978), as decisões sobre os elementos intracorporativos não podem ser tomadas separadamente, como afirma acontecer no composto de marketing para bens. Outro ponto relevante é que cada um dos elementos contribui para a definição do que vem ser o produto em serviços.

Os consumidores, suas crenças, seus desejos e suas necessidades completam a proposta de Grönroos (1978), sendo por ele denominados de "elementos extracorporativos do serviço". Os consumidores, ao contrário da crença de que apenas aceitam ou não aceitam os produtos que estão sendo ofertados, ajudam a moldar a oferta de serviços. Ademais, do ponto de vista do consumidor, também são parte do serviço os outros consumidores que estão fazendo suas compras/consumindo o serviço simultaneamente a ele. O profissional de marketing de serviços precisa reconhecer esse fato e considerar o papel ativo do consumidor no planejamento de marketing. A atitude dos consumidores em relação à produção do serviço, a organização da produção e o marketing do serviço devem ser favoráveis desde o início da prestação de serviços, sendo que devem ser tomadas ações imediatas se o consumidor se desapontar em alguma parte do processo.

A partir desse modelo inicial, de alguns anos de experiência e da inspiração em outro estudo, o de Eiglier e Langeard, publicado em 1976, Grönroos fez uma nova proposta de modelo para o gerenciamento do marketing de serviços em 1982, conforme se pode observar na Figura 5. 
Figura 5- Um modelo de marketing de serviço.

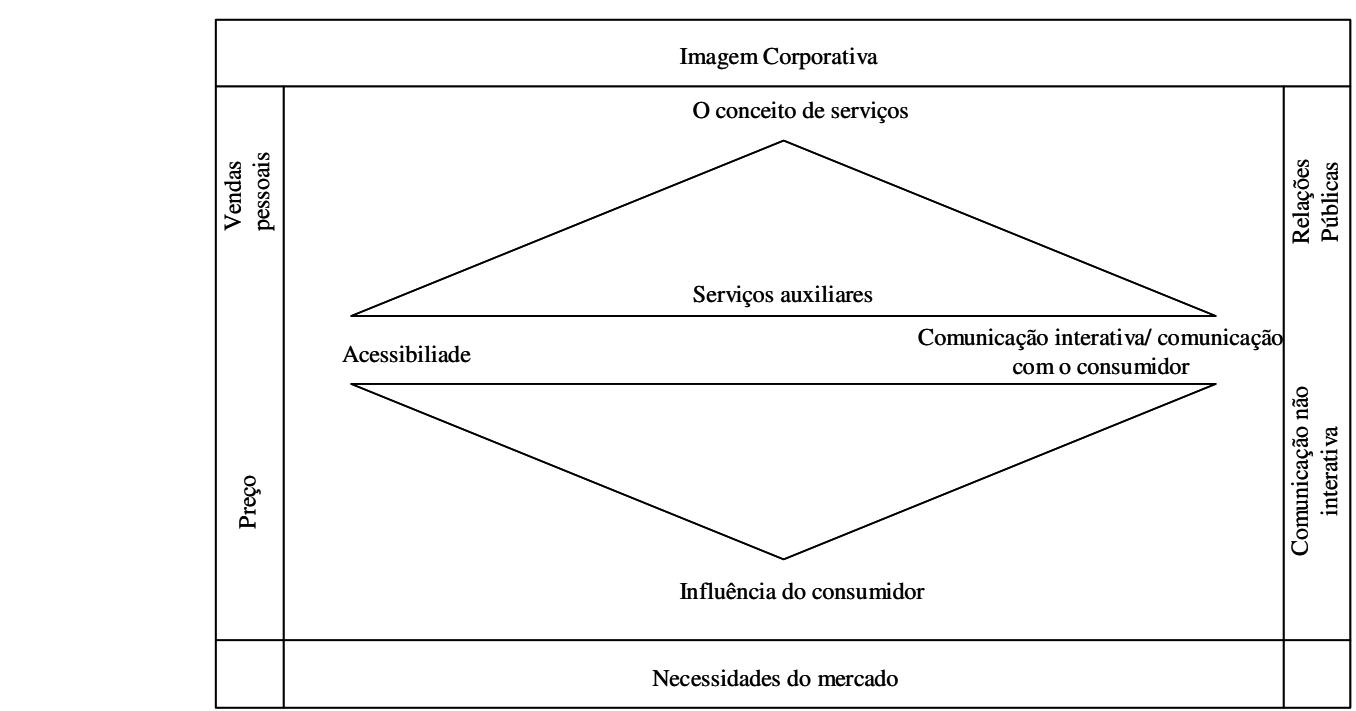

FONTE: GRÖNROOS, 1982.

Além das variáveis propostas no primeiro modelo, Grönroos (1982) acrescentou outros elementos que também julgou serem importantes no gerenciamento do marketing de empresas de serviços. Esses elementos são:

- Vendas pessoais;

- Comunicação não interativa;

- Relações públicas; e

- Preço.

Grönroos (1982) apenas identifica essas quatro variáveis, não explicando os elementos que compõem cada uma delas.

A proposta inicial de Grönroos pode ser considerada incompleta, uma vez que variáveis de decisão importantes como preço não fazem parte de seu modelo. De qualquer forma, o autor inovou ao fazer uma releitura sobre o $\mathrm{P}$ de praça, ao considerar fator de decisão os serviços auxiliares e também ao levar em conta o ponto de vista do consumidor.

Já em sua segunda proposta, Grönroos aprimorou seu modelo, acrescentando outras variáveis de decisão. No entanto, o autor foi apenas criativo na releitura dos 4 P's tradicionais (preço, praça, produto e promoção), considerando outros elementos que também fazem parte do processo decisório do composto de marketing. Sobre o produto, considerou-o como sendo o 
elemento central dos serviços e o completou com os serviços auxiliares. Para a praça deu a denominação de acessibilidade, que é a essência da distribuição. Quanto à promoção, considerou separadamente comunicação interativa, não interativa, relações públicas, entre outras, que de fato compõem o $\mathrm{P}$ de promoção. E, por fim, a variável preço apenas é citada, sem que haja considerações a respeito. Sendo assim, pode-se considerar que a proposta de Grönroos refere-se ao gerenciamento do composto de marketing em serviços.

\subsubsection{Modelo SOAR de Beaven e Scotti (1990)}

De acordo com Beaven e Scotti (1990), o composto de marketing é uma ferramenta conceitual inapropriada para serviços. Esses autores também compartilham da opinião de que a definição de serviços a partir de uma comparação com a manufatura conduziu a um pensamento distorcido.

Os serviços não podem ser conceituados como o "oposto" de bens, pois eles constituem ofertas de mercado distintas e únicas (BEAVEN, SCOTTI, 1990). Por isso, os autores propõem uma alternativa para o composto de marketing em serviços. O modelo por eles sugerido, denominado SOAR, apresenta as seguintes variáveis: Scripts do serviço (service scripts), Custo (outlay), Acomodação (accomodation) e Representação (representation).

Segundo defendem os autores, a primeira variável, o script do serviço, é importante porque os serviços devem ser considerados como processos cujo saldo pode ser definido como um resultado, não como produto final. À medida que um consumidor participa do processo de serviço, dois níveis de atividade ocorrem simultaneamente com o consumidor. Uma das atividades é a experiência atual dos eventos do processo de serviços, e a outra é a ação de revisar informações presentes na memória, que é uma variável incontrolável para o profissional de marketing. No decorrer do tempo, por meio de suas experiências e lembranças, os consumidores constroem imagens dos processos do serviço que se assemelham a fatos concretos, tangíveis. Essas impressões ou imagens mentais depositadas na memória são denominadas scripts.

Ademais, os scripts devem ser considerados como fator fundamental na definição das ofertas de serviços ou na modificação de projetos. Os autores sugerem que os profissionais de marketing compreendam as experiências correntes dos consumidores e seus modelos mentais internalizados ao planejarem novos negócios, decidirem sobre novas direções estratégicas, 
desenvolverem e fortalecerem operações de serviço, trabalhando, dessa forma, para melhorar o controle de qualidade. Não se deve esperar que o consumidor entre em conformidade com o serviço, mas sim que o serviço tenha sido desenvolvido para estar em conformidade com o usuário.

Já o outlay, segunda variável proposta no modelo, pode ser traduzido como sendo os custos envolvidos nas transações de serviços. Os consumidores investem muito mais na transação de serviços que na transação de bens. Além do desembolso financeiro, o consumidor despende tempo e esforço ao participar do processo de prestação de serviços. Sendo assim, Beaven e Scotti (1990) acreditam que o preço é um conceito muito estreito para ser considerado no marketing mix de serviços. Além disso, a definição de preços deve ser cuidadosa, posto que serviços ofertados a um preço reduzido podem continuar subutilizados por causa do custo de tempo, transporte e energia psíquica para o consumidor. A análise de custo versus benefício inclui todos as despesas que os consumidores estarão dispostos a suportar para participar do processo de serviço.

A acomodação, terceiro elemento do modelo proposto por Beaven e Scotti (1990), refere-se ao que denominam como missão fundamental do serviço, que é acomodar o consumidor e suprir suas necessidades no processo de prestação de serviços, julgando ser necessário que o conceito de distribuição seja, portanto, revisto. As decisões relacionadas com a acomodação devem ter como objetivo a diminuição de barreiras para a entrada, o consumo e a participação do consumidor no processo de prestação de serviços.

O quarto e último elemento do modelo de Beaven e Scotti (1990) é a representação, que, segundo os autores, seria uma releitura do $\mathrm{P}$ de promoção orientada para os serviços. Essa releitura se ampara no argumento de que, no processo de consumo dos serviços, os consumidores procuram oportunidades para atender às expectativas depositadas nos seus scripts mentais, ou seja, nas lembranças guardadas na memória e expectativas formadas a partir delas. No entanto, a promoção utilizada no marketing de bens é tipicamente associada a exageros, o que muito provavelmente levará o consumidor a se desapontar com a experiência dos serviços. Sendo assim, os autores propõem uma espécie de representação artística, sugerindo que os funcionários sejam os atores e o consumidor a estrela principal, como uma ferramenta muito mais adequada para atender às expectativas do cliente. A representação, nesse caso, promete apenas o que pode ser cumprido. 
O SOAR, embora seja pouco comentado por outros autores, também é um modelo bastante criativo. A variável denominada de script do serviço parece ser uma descrição do processo decisório do $\mathrm{P}$ de produto, pois remete ao processo de prestação de serviços e ao comportamento do consumidor nesse processo. O outlay, denominação dada para o processo decisório de preço, apresenta conceitos do marketing moderno, tratando de apontar a necessidade de os investimentos do consumidor serem considerados no processo de compra e na relação benefício versus custo do cliente. A acomodação, terceiro elemento do modelo, é um outro nome para a distribuição, em que se considera o conforto do consumidor no processo de consumo dos serviços. E, finalmente, a variável representação, que, segundo os próprios autores, é uma releitura da promoção, destaca o papel dos funcionários no processo de prestação de serviços.

Como se pode notar, o Modelo SOAR, assim como o modelo proposto por Grönroos (1982), é uma reinterpretação criativa do composto de marketing tradicional e dá nomes diferentes aos seus elementos. Além de ser pouco difundido, é um modelo que não agrega elementos significativamente diferentes para o gerenciamento do marketing de serviços.

\subsubsection{Composto de Marketing expandido}

A proposição clássica do composto de marketing, apresentada por McCarthy (1976) e convertida em um dos conceitos centrais na disciplina de marketing (SHAPIRO, 1985; ZEITHAML, BITNER, 2003), é constituída por quatro variáveis: preço, distribuição, produto e comunicação. Segundo Kotler e Keller (2005, p.17), o composto de marketing, também chamado de mix de marketing ou 4 P's, “[...] vem sendo definido como o conjunto de ferramentas de marketing que a empresa usa para perseguir seus objetivos de marketing". Os 4 P's também são denominados de variáveis de decisão e, por esse motivo, considerados controláveis, embora atuem em um ambiente em que a maior parte das demais variáveis são incontroláveis, por pertencerem ao ambiente externo à empresa (BENNETT, 1997).

De acordo com Shapiro (1985) e Bennett (1997), os 4 P's são o instrumento que uma organização tem para organizar o planejamento de marketing e traduzi-lo em um plano de ação. Shapiro (1985) enfatiza que os 4 P's foram muito bem aceitos nos programas de educação para executivos, pois constitui uma maneira efetiva e simples de gerenciar o marketing das empresas. O autor ressalta ainda que, apesar disso, sempre é possível incrementá-lo para torná-lo ainda melhor. 
A proposta dos 4 P's foi popularizada por Philip Kotler e é adotada de maneira generalizada por acadêmicos e profissionais de marketing, principalmente quando se trata da comercialização de bens. Sendo assim, o composto de marketing é o mais utilizado e difundido entre as propostas para o gerenciamento de marketing, ainda que na lógica do marketing de bens.

No sistema de marketing, representado na Figura 6, o composto de marketing destaca-se pelo fato de compor o ambiente-tarefa da entidade ofertante. $\mathrm{O}$ ambiente-tarefa é composto, portanto, pelos 4 P's, ferramentas de marketing que podem ser manipuladas para influenciar as trocas entre a entidade ofertante e a entidade recebedora. A decisão sobre essas variáveis não acontece isoladamente, mas sim de maneira integrada, ou seja, o preço deve estar adequado ao nível de qualidade do produto, que também deve ser compatível com os canais de distribuição e assim sucessivamente.

A entidade recebedora (mercado consumidor) estabelece uma relação de troca com a entidade ofertante, sendo que se deve considerar que o processo de troca é também influenciado por variáveis incontroláveis, como aspectos econômicos, políticos e culturais, ou seja, variáveis sobre as quais a empresa tem pouco ou nenhum poder de ação. A entidade ofertante, segundo a proposição de Campomar (1984), tenta compreender o comportamento da entidade recebedora por meio dos 4 O's (KOTLER, 1986):

\footnotetext{
- Objeto $\rightarrow$ o que se compra;

- Objetivo $\rightarrow$ por que compra;

- Operação $\rightarrow$ como compra;

- Organização $\rightarrow$ como se estrutura para compra.
}

Vale ressaltar que as variáveis controláveis teriam denominação mais adequada se fossem chamadas, por exemplo, de variáveis de decisão, composto de marketing, mix de marketing ou ainda instrumento de política de marketing, visto que não são controláveis em sua totalidade (CAMPOMAR, 1984). Condições de mercado, negociações de fornecedores e parceiros e certas exigências do consumidor limitam o controle da empresa frente a essas variáveis. Nesta dissertação os termos composto de marketing e variáveis de decisão são preferencialmente utilizados. 
Figura 6 - O sistema de marketing.

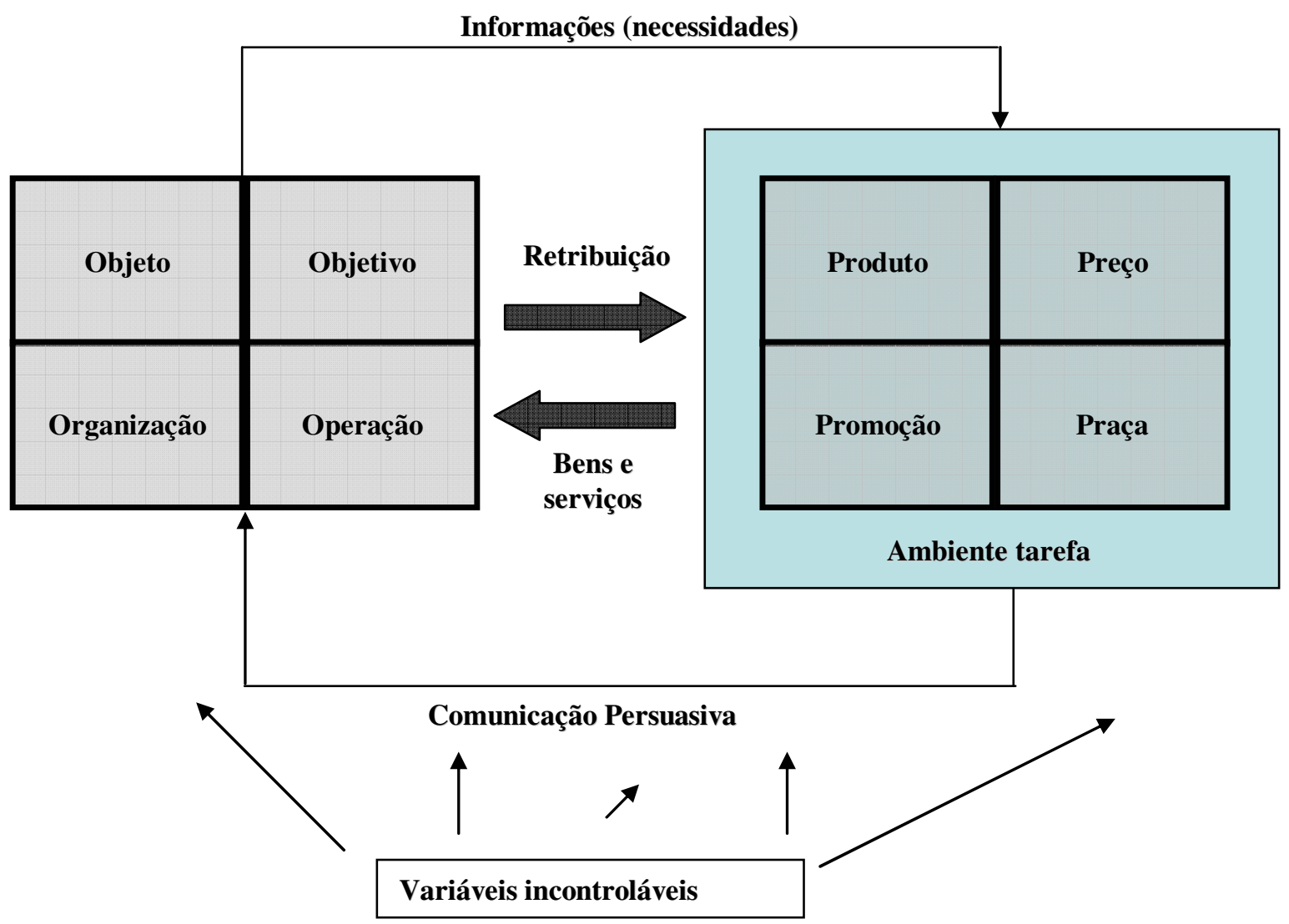

FONTE: CAMPOMAR, 1984, p.44.

Em função da natureza dos serviços e de suas características, diversos autores - como Araújo e Gorgulho (2002), Gilmore e Carson (1996), Fryar (1991), McLean (1994), Goldsmith (1999), Shostack (1977) e Grönroos (1994; 2000) - criticam a composição clássica do composto de marketing e propõem abordagens alternativas para o gerenciamento de serviços, conforme apresentado anteriormente. Segundo Waterschoot e Van Den Bulte (1992), a classificação das ferramentas do composto de marketing em 4 P's obteve ampla aceitação nas últimas décadas, apesar das críticas e proposições de modelos alternativos.

Se na década de 70 Grönroos (1978) já apontava que o planejamento do composto de marketing de serviços era um assunto crítico e que até então não havia sido devidamente definido, mais recentemente, Grove et al. (2003), em pesquisa realizada com os principais estudiosos do marketing de serviços sobre o futuro dos estudos nessa área, constataram que esse assunto ainda requer pesquisas, concluindo, igualmente, que precisa ser melhor entendido e definido. 
Em relação à utilização do composto de marketing no marketing de serviços, autores como Shostack (1977) e Grönroos $(1978 ; 2000)$ declaram que o composto de marketing clássico deriva da manufatura de bens, tendo, portanto, uma visão manufatureira, e baseia-se no que Grönroos (2000) denomina de outcome consumption (que pode ser entendido como o consumo daquilo que já está pronto, produzido). Segundo esses autores, quando se trata de serviços, diferentemente do que ocorre na transação de bens, o consumidor participa do processo de produção. Sendo assim, quando o processo de produção e o consumo ocorrem em paralelo, o marketing deve trabalhar de maneira diferente.

Para McLean (1994) e Goldsmith (1999), a composição tradicional do composto de marketing não enquadra as características dos serviços, isto é, intangibilidade, inseparabilidade, heterogeneidade, perecibilidade e ausência de propriedade. Dessa forma, um composto de marketing expandido tem sido desenvolvido, já que os profissionais de marketing de serviços devem atuar de maneira diferente dos profissionais que trabalham com bens (GILMORE, CARSON, 1996; FRYAR, 1991).

Alguns estudiosos da área de serviços propõem o gerenciamento de outras variáveis controláveis, constituindo assim o chamado composto de marketing expandido. Magrath (1986), Hoffman e Bateson (2003), Zeithaml e Bitner (2003) e Lovelock e Wirtz (2006) falam sobre o $\mathrm{P}$ de processos, o $\mathrm{P}$ de pessoas e o $\mathrm{P}$ de phisical elements (elementos físicos). Originalmente, essa proposta foi feita por Booms e Bitner (1981, apud XAVIER, 2005), que definem cada um dos elementos extras do composto de marketing de serviços da seguinte maneira:

- Pessoas $\rightarrow$ Variável que abrange os empregados ou "atores" e todos os envolvidos na entrega do serviço, compreendendo: as pessoas da organização e as suas atitudes na prestação do serviço; treinamento dos funcionários; incentivos; comportamento dos consumidores e grau de envolvimento com outros clientes. Tendo em vista a simultaneidade entre a produção e o consumo em serviços, os funcionários da empresa ofertante ocupam uma posição-chave na opinião de qualidade formada pelo cliente.

- Processo $\rightarrow$ Abrange os procedimentos, os mecanismos e o fluxo de atividades pelos quais um serviço é consumido. 
- Evidências físicas $\rightarrow$ Abrange o ambiente no qual um serviço é prestado, assim como materiais impressos e outros itens tangíveis, que podem tornar palpável a promessa que um serviço representa.

Segundo esses autores, é importante gerenciar o processo de prestação dos serviços, pois a entrega do serviço é interativa (cliente-empresa) e, por isso, deve acontecer da melhor maneira possível para manter os padrões de qualidade. Já as evidências físicas fazem parte da tentativa de tangibilização dos serviços e dão pistas sobre a qualidade dos serviços prestados. Por fim, as pessoas são uma importante variável a ser controlada no sentido de diminuir a variabilidade do serviço prestado e aumentar a qualidade, uma vez que os funcionários são o elo entre a empresa e o cliente.

$* * * * *$

Para se concluir este subitem sobre as propostas para o gerenciamento do marketing de serviços, vale conferir o Quadro 2, que resume os modelos apresentados.

Quadro 2 - Modelos de gerenciamento do marketing de serviços.

\begin{tabular}{|c|c|}
\hline Publicação & Proposta \\
\hline Shostack (1977) & $\begin{array}{l}\text { Modelo Molecular: } \\
\text { - O foco é definir o núcleo central da oferta de marketing, em torno da qual o } \\
\text { composto de marketing será desenvolvido. } \\
\text { - Auxilia nas definições de prioridades e abordagens na elaboração do } \\
\text { composto de marketing. }\end{array}$ \\
\hline Grönroos (1982) & $\begin{array}{l}\text { - É uma releitura do composto de marketing tradicional. } \\
\text { - Criativo, porém não é inovador } \\
\text { - Variáveis de decisão sugeridas: Acessibilidade, serviços auxiliares, } \\
\text { comunicação pessoal, vendas pessoais, comunicação não interativa, } \\
\text { relações públicas e preço }\end{array}$ \\
\hline Beaven e Scotti (1990) & $\begin{array}{l}\text { Modelo SOAR: } \\
\text { - O Modelo SOAR também é uma releitura do composto de marketing } \\
\text { tradicional. } \\
\text { - Variáveis de decisão: Scripts do serviço (service Scripts), Custo (outlay), } \\
\text { Acomodação (accomodation) e Representação (representation). }\end{array}$ \\
\hline
\end{tabular}


Booms e Bitner (1981, apud XAVIER, 2005)

Magrath (1986)

Lovelock e Wirtz (2006)

Hoffman e Bateson (2003)
7 P's

- 4 P's do composto de marketing tradicional (preço, distribuição, produto e comunicação).

- 3 P's adicionais: Processos, Pessoas e Evidências físicas.

FONTE: Elaborado com base em SHOSTACK, 1977; GRÖNROOS, 1978; BEAVEN, SCOTTI, 1990; BOOMS, BITNER, 1981, apud XAVIER, 2005; MAGRATH, 1986; e LOVELOCK, WIRTZ, 2006.

Conforme exposto, tais modelos são releituras criativas do composto de marketing tradicional, vez ou outra considerando elementos que não fazem parte de tal composto. Já a proposta do composto de marketing expandido, que parece ser a proposta mais difundida entre os autores que estudam o marketing de serviços, é uma tentativa forçosa de encaixar o composto de marketing na realidade dos serviços, sendo que é sabido que o composto de marketing é de fato uma simplificação da realidade tanto para fins didáticos quanto para fins gerenciais. Ademais, os 3 P's adicionais tratam sim de questões relevantes em serviços, mas não são merecedores do mesmo destaque que os 4 P's originais.

Sendo assim, nesta dissertação optou-se por abordar a composição clássica do composto de marketing, ou seja, os 4 P's, uma vez que se acredita que os demais P's propostos por outros autores podem ser considerados como subitens dos P's originais de McCarthy. Nas seções seguintes poder-se-á conferir discussão sobre cada um dos P's.

A verdade é que muitas críticas são feitas sobre a utilização do composto de marketing para a tomada de decisões tanto em bens quanto em serviços, sendo verdade também que nenhuma outra classificação, modelo ou fórmula foi capaz de se sobrepor a essa antiga, difundida e precursora proposição.

\subsection{Composto de marketing}

O composto de marketing tradicional, formado pelas variáveis de decisão preço, distribuição, produto e comunicação, também chamadas de variáveis controláveis, será discutido nesta seção com base na revisão da literatura dos principais livros e artigos sobre o marketing de serviços. 


\subsubsection{Preço}

De acordo com Hoffman e Bateson (2003), a variável preço em marketing de serviços é a menos estudada. Contudo, o seu gerenciamento é o mais difícil quando comparado ao das demais variáveis. Além disso, sua influência na decisão de compra do consumidor desempenha um papel diferente daquela exercida por essa mesma variável quando o foco é um produto. Essencialmente, a definição de preços em serviços leva em consideração os mesmos fatores avaliados para a sua determinação em bens, o que difere, no entanto, segundo Hoffman e Bateson (2003), é o conteúdo desses fatores.

A influência diferenciada do preço em serviços se dá, principalmente, porque é um forte indicador da qualidade do serviço prestado, sendo sua definição, por isso, muito importante e delicada (REARDON et al., 1996; ZEITHAML, BITNER, 2003). Há situações em que o consumidor utiliza outros sinais para opinar sobre o nível de qualidade dos serviços, como uma marca que denota a reputação da empresa. No entanto, em certas ocasiões pode não haver essa possibilidade e, então, o preço se torna um elemento fundamental.

De acordo com Zeithaml e Bitner (2003), o risco percebido pelo consumidor no processo de compra ou consumo do serviço também contribui com o argumento de que preço é sinônimo de qualidade. Quanto maior o risco, mais o consumidor faz essa associação - pode-se imaginar, por exemplo, serviços prestados por cabeleireiros, dentistas ou médicos, que têm grande impacto sobre a saúde física ou estética dos consumidores.

A falta de conhecimento do consumidor em relação às ofertas de serviços também deve ser levada em conta no processo de determinação de preços. Alguns fatores contribuem para isso. Em primeiro lugar, de acordo com Hoffman e Bateson (2003), há dificuldade de comparação entre os serviços dos concorrentes, dada a maior variação existente na prestação de serviços e também a maior flexibilidade na formatação das suas ofertas (ZEITHAML, BITNER, 2003) do que na venda de bens. Essa dificuldade de comparação entre os serviços concorrentes confere às empresas de serviços, segundo Hoffman e Bateson (2003), a tendência de inelasticidade de suas curvas de demanda, ou seja, mudanças de preços não levam a grandes alterações nas quantidades consumidas. 
Em segundo lugar, a falta de conhecimento de preços de referência é outro fator que contribui para a desinformação do consumidor em relação aos serviços ofertados, conforme argumentam Zeithaml e Bitner (2003). Essas autoras definem o preço de referência como “[...] uma posição de preço na memória para um bem ou serviço" (p.380). Isso se deve ao desconhecimento por parte do consumidor das possíveis fontes geradoras de custo de um serviço, à dificuldade de comparação de serviços concorrentes e à tímida divulgação de preços por parte das empresas, seja pela complexidade da sua determinação dada pelas necessidades individuais e especificidades de cada consumidor, seja pela sua invisibilidade (preços não facilmente disponíveis para o consumidor).

O fator preço é, de acordo com Zeithaml e Bitner (2003), crucial para o processo de decisão de compra, o que impõe a necessidade de as empresas avaliarem com cuidado suas deliberações quanto a essa variável. Lovelock e Wirtz (2006) alertam que há a necessidade de se fazer uma comunicação clara de preços para o consumidor, uma vez que definições confusas ou duvidosas podem resultar em acusações de comportamento antiético e perda de confiança na empresa prestadora de serviços.

Vale considerar, ainda, que os custos não monetários envolvidos nas transações de serviços são maiores que aqueles abarcados na comercialização de bens. Fazem parte dos custos não monetários os custos de tempo, pesquisa, conveniência e psíquicos gastos pelo consumidor no processo de aquisição ou contratação de um serviço. É importante que as empresas tomem conhecimento sobre esse tipo de custo, uma vez que são relevantes para a determinação do nível de preços. Lojas de serviço que atendem $24 \mathrm{~h}$, por exemplo, têm um nível de conveniência maior que outras e, sendo assim, poderiam cobrar um valor maior por isso (ZEITHAML, BITNER, 2003).

Postas todas essas considerações sobre o comportamento do consumidor em relação ao preço, podem-se analisar as diferentes propostas de definição dessa variável em serviços.

A determinação do nível de preços em serviços, de acordo com Bessom e Jackson (1975), possui a mesma lógica que aquela em relação a bens: precisa cobrir os custos de produção e contribuir para o lucro da empresa. Da perspectiva do consumidor o preço deve ser igual ao conjunto de benefícios por ele recebido, o que torna a avaliação difícil, posto que os benefícios auferidos pelo cliente são, em geral, intangíveis. 
Segundo Boone e Kurtz (2006), no processo de definição de preços, o profissional de marketing deve considerar a demanda pelo serviço, a produção, os investimentos em marketing, os custos administrativos e a influência da concorrência. Já para Gilmore e Carson (1996), as decisões de preço em serviços abrangem: a escolha do preço adequado para uma série de serviços; a adaptação das estruturas de preço de acordo com diferentes níveis de demanda; e uma certa criatividade na precificação dos serviços, de forma a manter a competitividade e a diferenciação. Em muitos casos, a negociação de preço entre o consumidor e a empresa ou profissional que está oferecendo o serviço é inerente ao processo de compra. Exemplos disso podem ser observados na contratação de seguros, no conserto de equipamentos etc.

A determinação de preços em serviços pode ocorrer de acordo com três estratégias que se inter-relacionam, segundo indicam Lovelock e Wirtz (2006), Zeithaml e Bitner (2003) e Hoffman e Bateson (2003). A primeira estratégia é a de custos; a segunda leva em consideração a entrega de valor ao consumidor; e a terceira é a de definição de preços pelos concorrentes. Zeithaml e Bitner (2003) destacam que na prática as empresas devem considerar cada uma das três estratégias para tomar a decisão final de precificação.

Para Lovelock e Wirtz (2006), a estratégia de determinação de preço por meio da identificação de custos é mais difícil para produtos intangíveis que para produtos tangíveis. Zeithaml e Bitner (2003) e McLean (1994) argumentam que a execução dessa estratégia se torna complexa pela própria dificuldade de identificação de fontes de custos - dificuldade essa ocasionada pela natureza intangível dos serviços - e de comparação da oferta da empresa com outras ofertas no mercado, fato causado pela falta de homogeneidade entre os serviços.

O custo do trabalho empregado para a execução de um serviço - pode-se considerar custos de materiais, mão-de-obra, estocagem, transporte e armazenamento - é mais difícil de se precificar e pode não ser compatível com o valor percebido. Pode-se imaginar, por exemplo, a tentativa de comparação entre um salão de cabeleireiros famoso e bem estruturado e um salão de bairro qualquer. As estruturas de custo são bastante diferentes e as expectativas dos consumidores também, evidenciando que a identificação dos custos de fato não é simples.

Reardon et al. (1996) acrescentam ainda que a demanda flutuante e, sobreposta a esta, a perecibilidade dos serviços dificultam ainda mais o processo de definiçãa de preços em 
serviços. Por conta disso, muitas vezes os profissionais de marketing devem desenvolver mecanismos de ajuste de preços de acordo com o comportamento de mercado.

Há duas maneiras principais de determinação de preços por meio da estratégia de custos. A primeira requer o entendimento dos seguintes conceitos, assim definidos por Lovelock e Wirtz (2006):

- Custos fixos: são os custos a que o prestador de serviços ficará sujeito mesmo que não haja a venda do serviço. Pode-se citar como exemplo o aluguel do estabelecimento em que o serviço é prestado.

- Custos variáveis: são aqueles que ocorrem em decorrência da venda adicional de um serviço. Em geral, no setor de serviços os custos variáveis são bastante reduzidos. O custo de acomodação de um hóspede a mais no hotel ou de um espectador a mais no teatro, por exemplo, são muito baixos.

- Custos semivariáveis: são custos que estão entre os fixos e os variáveis e representam despesas que aumentam ou diminuem proporcionalmente ao aumento ou diminuição do volume de vendas. Pode-se imaginar, nesse caso, a contratação de profissionais temporários em um hotel para o período de férias.

A partir dessa distinção entre os custos é possível que os gerentes tomem decisões sobre qual preço cobrar do cliente, tendo como base estabelecer um ponto de equilíbrio - considerandose o volume de vendas que tornará a empresa lucrativa - mediante a cobrança de determinado preço.

Outra forma de determinação de preços por meio dos custos, esta mais comumente empregada por profissionais de serviços, é a utilização da abordagem complexa do custo por atividade. Tal estratégia identifica as atividades que dão suporte direto ou indireto à oferta de serviços e a elas determina o custo associado. Quando bem gerenciada, esta estratégia possibilita ter uma boa idéia do nível de custos incorridos pela empresa no processo de prestação de serviços.

Ainda em relação ao custo, muitas vezes o cliente não sabe qual valor irá pagar até que a prestação do serviço se encerre. Em geral, o custo fixo é alto, porém o custo variável é baixo, e as economias de escala tendem a ser limitadas. 
A segunda abordagem para a determinação de preços, por meio da estratégia de criação de valor para o consumidor, considera que nenhum cliente pagará mais do que pondera valer um determinado serviço. Entende-se, nesse caso, que o consumidor considera a relação benefícios-custos em sua decisão de compra. Sendo assim, é importante fazer uma investigação do comportamento do consumidor para que se compreendam as características do serviço que são valorizadas. Muitas empresas acabam oferecendo níveis de serviços diferenciados para seus consumidores, uma vez que nem todos valorizam os mesmos benefícios. Fazem isso com o corte ou a adição de serviços suplementares ao serviço principal (LOVELOCK, WIRTZ, 2006).

Em relação ao lucro, o preço por conjunto de serviços suplementares complica a determinação dos preços individuais de cada serviço, sendo o preço por conjunto mais eficaz nesse contexto (HOFFMAN, BATESON, 2003). Os serviços suplementares serão abordados na seção sobre a variável de decisão produto, mas, para que aqui se possa ter um entendimento simplificado, vale esclarecer que são aqueles que não fazem parte da oferta principal de um serviço, como, por exemplo, o serviço de estacionamento em um restaurante ou ainda a disponibilidade de crédito em um supermercado.

Zeithaml e Bitner (2003) chamam a abordagem de determinação de preços por meio da criação de valor para o cliente de "determinação pela demanda". Segundo as autoras, nesta estratégia há a necessidade de se fazer o ajuste monetário do preço para refletir o valor dos custos não monetários incorridos pelo consumidor (custos de tempo, pesquisa, conveniência e psíquicos). Outro ponto é que as informações sobre os custos envolvidos no processo de prestação de serviços não estão disponíveis para os consumidores e, dessa maneira, não deveriam ser o foco central da determinação de preços.

Zeithaml e Bitner (2003) sugerem, para melhor aproveitamento e utilização dessa abordagem, que sejam considerados quatro diferentes tipos de entendimento de valor para o cliente, conforme mostra a Figura 7: 
Figura 7 - Resumo das estratégias de precificação para quatro definições de valor.
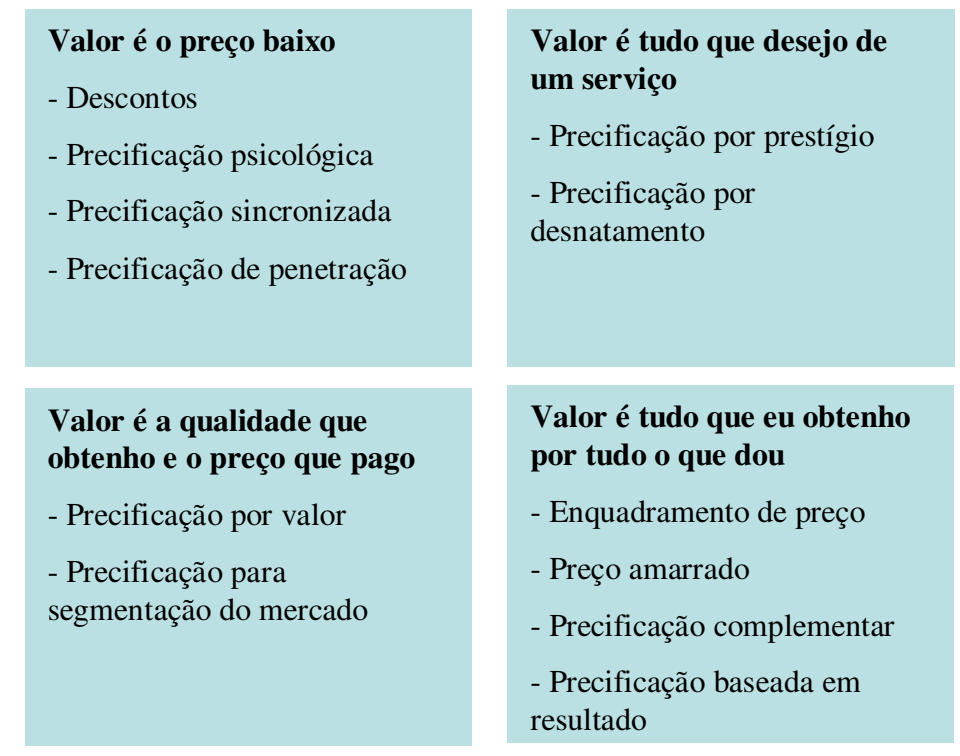

FONTE: ZEITHAML, BITNER, 2003, p.396.

Para alguns clientes o preço baixo é o valor determinante para a compra. Nesse caso, as empresas podem trabalhar com descontos, oferecendo reduções de preços de seus serviços prestados. A precificação psicológica, ferramenta que pode ser utilizada para esse tipo de cliente, utiliza preços alguns centavos abaixo de um preço cheio para que os consumidores pensem que estão comprando por um preço mais baixo. Sendo assim, em vez de cobrar $\mathrm{R} \$ 20,00$, o prestador de serviços pode cobrar, por exemplo, $\mathrm{R} \$ 19,90$. A precificação sincronizada diz respeito ao gerenciamento do preço de acordo com a sensibilidade do consumidor, seja em relação à localização (localização de uma cadeira em um show), ao tempo (preços diferenciados para viagens fora de temporada), à quantidade (reduções de preços para clientes que comprarem maiores quantidades) ou ainda como uma estratégia para incentivar o novo consumidor a se tornar um consumidor regular. Por fim, a precificação por penetração consiste na cobrança de valores menores quando do lançamento de um serviço no mercado para incentivar o consumo ou a experimentação.

A segunda estratégia de precificação, de acordo com Zeithaml e Bitner (2003), é oposta à explicada anteriormente. Para clientes que entendem que o "valor é tudo em um serviço" o preço é o fator menos importante. Para esse tipo de consumidor a qualidade da prestação de serviços está acima de tudo. Assim, as empresas podem decidir precificar por prestígio, estabelecendo os níveis de preços de acordo com o status que o serviço confere ao cliente - é o caso de restaurantes, hotéis, academias de luxo. Outra forma de precificar serviços 
oferecidos a esse tipo de cliente é a precificação por desnatamento, que, de acordo com Zeithaml e Bitner (2003), deve ser utilizada para serviços novos que oferecerão tantos benefícios e melhorias que o consumidor estará disposto a pagar preços mais altos por eles.

$\mathrm{Na}$ estratégia de "valor é a qualidade que obtenho pelo preço que pago" evidencia-se a importância dada pelo consumidor à relação benefício-custo. Nessa estratégia a empresa pode precificar pelo valor que cada um dos segmentos da sua massa de clientes procura ou ainda optar por identificar diferentes segmentos de mercado que dão importâncias distintas à qualidade e ao preço.

Por fim, há quatro diferentes tipos de atuação na precificação do tipo "valor é tudo o que obtenho por tudo o que dou". A empresa pode optar por fazer o enquadramento de preço de forma a fornecer subsídios ao consumidor para formar um preço de referência, organizando as informações na sua mente a fim de fazê-lo conceber uma idéia bastante clara do preço. Para esse tipo de cliente a empresa pode, ainda, ofertar preços amarrados, fazendo com que o consumidor valorize o pacote de serviços ofertado pela empresa. Pode também determinar os preços por meio da precificação complementar, que ocorre quando a empresa decide ofertar, por exemplo, um preço fixo por determinado serviço mais um preço variável de acordo com as taxas de utilização. Finalmente, a empresa pode definir seus preços pelos resultados alcançados por meio da prestação de serviços, o que ocorre, em geral, em serviços prestados por advogados.

Sob uma outra óptica, Hoffman e Bateson (2003) acrescentam que a determinação de preços deve depender do valor que o cliente dá a um serviço, compreendendo três estratégias distintas: satisfação, relacionamento e eficiência. A estratégia de satisfação tem como objetivo reduzir o risco percebido do consumidor. Para tanto, as empresas podem oferecer preços fixos para seus serviços, preços por benefícios ou ainda garantias. O preço determinado pelo relacionamento visa ao estabelecimento de relacionamentos de longo prazo. Nesse caso, as empresas podem firmar contratos mais longos por um pacote determinado de benefícios. Por fim, a estratégia de determinação de preços por meio da eficiência refere-se à prestação do melhor serviço ao preço mais baixo. Dessa forma, a administração de custos por parte da empresa é fundamental. 
A terceira e última estratégia para a determinação de preços, conforme a concorrência, é a mais adequada para empresas que oferecem produtos indiferenciados, uma vez que quando o consumidor não identifica diferenças significativas entre os concorrentes de mercado o que norteia a decisão de compra é o preço. De acordo com Zeithaml e Bitner (2003), o problema da definição de preços baseada na concorrência é que empresas de pequeno porte podem decidir cobrar muito pouco para que sejam viáveis. Na maior parte das vezes a comparação entre dois prestadores de serviços é complicada, dada a heterogeneidade que existe na oferta de serviços. Além disso, o preço pode não refletir a qualidade percebida pelo cliente.

Outro ponto relevante, conforme indicam Lovelock e Wirtz (2006), é a questão da identificação da base de determinação de preços, ou seja, o que exatamente deve ser levado em consideração para a determinação do preço de um serviço. Um exemplo pode ser os serviços de um advogado, que devem ser cobrados pelo tempo despendido pelo profissional na ação judicial ou pelos benefícios gerados a seu cliente (há advogados que cobram um percentual sobre o valor recuperado ou a indenização).

Ainda sobre a decisão de preço, as empresas precisam determinar de que maneira cobrarão pelo serviço principal e pelos serviços suplementares. Lovelock e Wirtz (2006) chamam a cobrança única de todos os serviços suplementares de "determinação de preços conjugados". Os preços conjugados são garantia de uma receita fixa para a empresa, sem que necessariamente ela preste o serviço contratado. Os preços não conjugados são mais flexíveis, no entanto o cliente pode não gostar de comprar um serviço e ter de pagar diversas taxas extras para poder usufruí-lo em sua totalidade.

De acordo com Reardon et al. (1996), há uma distinção da estratégia de definição de preços quando aplicada a empresas prestadoras de serviços em que a intangibilidade é predominante e a empresas prestadoras de serviços com base em bens. Reardon et al. (1996) realizaram uma pesquisa com 304 empresas varejistas nos Estados Unidos para investigar como os profissionais dos varejos de serviços e dos varejos de bens tomam suas decisões em relação ao composto de marketing de serviços. No que diz respeito à variável preço, os varejistas de serviços a consideram como tendo menor importância quando comparados aos profissionais de varejos de produtos. Isso indica que a oferta ímpar de cada empresa leva o consumidor a ser mais tolerante a preços e, por isso, menos suscetível à oferta de serviços substitutos. 
A definição de preços em serviços, segundo Reardon et al. (1996), pode incluir políticas mais frouxas, mantendo-os sob certa incerteza, não sendo estratégica a resposta rápida para mudanças no curso de ação do concorrente ou no ambiente. Sendo assim, as definições de preços devem considerar muito mais fatores internos da empresa do que fatores mercadológicos/concorrenciais. Os autores sugerem que as empresas devam prestar mais atenção nas demandas dos consumidores do que nas mudanças dos competidores.

O estudo da variável preço em serviços leva a compreender que as estratégias existentes para a definição de preço são essencialmente as mesmas existentes para bens, ou seja, estratégia de definição por custo, concorrência ou valor. O Quadro 3 mostra um resumo das principais decisões que devem ser tomadas no processo decisório da variável preço e considerações sobre o comportamento do consumidor

Quadro 3 - Resumo sobre as principais considerações para o gerenciamento do preço em serviços.

\begin{tabular}{|l|l|}
\hline Considerações & Alternativas \\
\hline Comportamento do consumidor & $\begin{array}{l}\text { - Risco percebido } \\
\text { - Falta de conhecimento sobre a oferta de serviços. } \\
\text { - Falta de conhecimento de preços de referência. } \\
\text { - Custos não monetários (tempo, pesquisa, conveniência, } \\
\text { psíquicos). }\end{array}$ \\
\hline Estratégias para definição do preço & $\begin{array}{l}\text { - Custo: identificação de custos fixos, variáveis e semivariáveis. } \\
\text { - Valor ao consumidor: o preço deve refletir o valor dos custos } \\
\text { não monetários. } \\
\text { - Concorrência: definição de preços com base nos preços } \\
\text { praticados pela concorrência. }\end{array}$ \\
\hline FONTE: Elaborado com base em LOVELOCK, WIRTZ, 2006; HOFFMAN, BATESON, \\
2003; e ZEITHAML, BITNER, 2003.
\end{tabular}

Na próxima seção serão discutidos fatores importantes para a decisão da variável distribuição em serviços. 


\subsubsection{Distribuição}

A variável distribuição em serviços desenvolveu-se pouco ao longo das últimas décadas, uma vez que o setor de serviços era bastante regulamentado e pouco competitivo, o que isentava os profissionais de marketing de serviços da necessidade de desenvolver canais de distribuição para serem competitivos no mercado (OUMLIL, RAO, 1993). Diferentemente daquelas que prestam serviços, as empresas que fabricavam bens precisam de canais físicos para a distribuição de seus produtos, o que, de certa forma, facilita a compreensão do tipo de canal necessário.

Para a distribuição de serviços se faz necessário considerar algumas variáveis importantes, como o número de intermediários, os tipos de intermediários, a alocação de valor em cada elo da cadeia de distribuição e os tipos de materiais e tecnologias que precisam estar envolvidos nesse processo (OUMLIL, RAO, 1993). A fim de tomar essas decisões, as empresas, de acordo com o tipo de negócio, podem optar por ter uma combinação de diferentes canais de distribuição, mesclando, por exemplo, visitas pessoais ao local da prestação de serviços e transações eletrônicas, em que não há nenhum contato pessoal. De acordo com Lovelock e Wirtz (2006), o desenvolvimento dos meios eletrônicos possibilitou uma expansão no âmbito de atuação das empresas prestadoras de serviços, principalmente para os prestadores baseados em informação, que podem realizar a entrega do serviço em qualquer lugar do mundo.

A classificação de Zeithaml e Bitner (2003) quanto à distribuição de serviços é bastante simplificada quando comparada à de Lovelock e Wirtz (2006), embora remeta a muitas questões para discussão. Segundo as autoras, a distribuição em serviços pode ocorrer de três maneiras distintas: por meio de canais diretos ou de propriedade da empresa; por meio de intermediários; e por meio de canais eletrônicos, a forma mais recente (ZEITHAML, BITNER, 2003).

A distribuição por meio de canais diretos ou de propriedade da empresa ocorre quando o próprio prestador de serviços entrega o serviço ao cliente. Isso acontece com médicos, dentistas, cabeleireiros, lavanderias, e, sendo assim, a distribuição é limitada. Grandes empresas também podem optar pela distribuição direta, e isso ocorre quando se decide pela propriedade de todos os pontos de distribuição, ou seja, as lojas de serviços são de propriedade da própria empresa de serviços. Uma das vantagens da distribuição direta é que a 
empresa tem controle total sobre sua performance de atendimento, vendas etc. Por outro lado, o maior impedimento para esse tipo de distribuição é o crescimento limitado, dado que a empresa precisa assumir sozinha todos os riscos financeiros envolvidos.

Os serviços também podem ser distribuídos por intermediários. Zeithaml e Bitner (2003) argumentam que os intermediários têm papel importante para a empresa de serviço, já que podem ser responsáveis pela co-produção e pelo fornecimento local dos serviços, desempenhando papel de elo entre a empresa principal (dona da marca) e o cliente. No caso da decisão sobre essa variável em serviços, questões de estoque, seguro e detenção de diretos sobre a mercadoria não fazem sentido. Segundo classificam essas autoras, os intermediários em serviços podem ser franqueados ou agentes/corretores. Cada um possui vantagens e desvantagens, de acordo com o tipo de serviço que está sendo prestado.

De modo geral, a distribuição de serviços por intermediários gera alguns conflitos entre a empresa titular e o canal. Essa modalidade de distribuição pode, por exemplo, suscitar: conflitos entre os objetivos da empresa titular do serviço e o desempenho alcançado pelo intermediário; conflitos entre custos e remuneração; dificuldade de controlar a qualidade e a variabilidade na prestação de serviços dos diversos pontos de venda ou intermediários; problemas de transferência de poder para o franqueado; e, finalmente, problemas na definição dos papéis a serem desempenhados por cada um - intermediário e empresa titular (ZEITHAML, BITNER, 2003).

A franquia se tornou uma maneira rápida de expandir a distribuição de serviços, diminuindo o investimento da empresa principal. De acordo com Boone e Kurtz (2006), as franquias são utilizadas como canais de distribuição principalmente quando o serviço não pode ser consumido ao mesmo tempo em que se dá a sua produção. Ademais, é uma forma de as empresas titulares do serviço superarem ineficiências de distribuição e aumentarem a produção (OUMLIL, RAO, 1993).

Todavia, é também uma forma de atuação que pode gerar muitos problemas de agenciamento, uma vez que os interesses do franqueado e do franqueador podem não ser comuns. Para diminuírem esse risco as empresas franqueadoras precisam desenvolver itens de controle e acompanhar constantemente a operação do franqueado (LOVELOCK, WIRTZ, 2006). 
As franquias permitem a rápida expansão do negócio, propiciam ganhos de conhecimento de mercados locais, bem como a divisão dos riscos envolvidos na expansão do negócio. Em contrapartida, os franqueadores podem ter dificuldades em manter e motivar o franqueado. Além disso, sua reputação pode sofrer prejuízos quando há a divulgação de disputas ocorridas entre franqueadores e franqueados. Outros fatores negativos da opção por esse tipo de intermediário são as dificuldades em se manter o nível de serviço igual em todas as franquias e o fato de o relacionamento com o consumidor ficar a cargo do franqueado, fazendo com que a empresa titular tenha pouco ou nenhum contato com seu consumidor final.

Já a atuação por meio de agentes ou corretores, que são pessoas que agem em nome do titular de um serviço e aptas a negociar e fechar negócios com clientes, possui um outro conjunto de vantagens e desvantagens. Como vantagens Zeithaml e Bitner (2003) apontam:

- A redução do custo de distribuição: não há custos de estrutura de lojas de serviços;

- Aproveitamento das habilidades dos agentes: como geralmente se especializam em um mercado, possuem conhecimentos mais aprofundados sobre a concorrência, os produtos vendidos etc;

- Representação ampla em comparação às lojas de serviços: agentes e corretores costumam se deslocar por uma determinada região, atendendo um mercado mais amplo;

- Conhecimento do mercado: como os agentes atuam em uma região específica, passam a conhecer as especificidades de cada localidade;

- Escolha do cliente: para o cliente a existência de agentes de vendas é interessante, uma vez que ele oferta serviços de diversas empresas. Assim, não há a necessidade de empenhar tempo dirigindo-se a diversas lojas de atendimento.

Já as desvantagens da utilização de agentes ou corretores como meio de distribuição são duas. Em primeiro lugar, gera dificuldade para controlar o preço, posto que o corretor tem autonomia para negociá-lo com cada cliente. Isso pode acarretar problemas se clientes notarem que estão pagando preços diferentes pelo mesmo serviço. Em segundo lugar, suscita conflitos quando o agente ou corretor faz a distribuição para múltiplas empresas. Se, por um lado, isso é positivo do ponto de vista do cliente, para a empresa de serviços pode ser ruim, pois o agente pode, em muitos casos, defender a oferta do concorrente. 
Um outro canal de distribuição que pode ser utilizado em serviços é o eletrônico. A Internet e o comércio eletrônico revolucionaram esse mercado. Em geral, os serviços mais comumente prestados por meio desse canal referem-se a informações, educação e entretenimento. O canal eletrônico colabora para a maior padronização dos serviços, tem custo baixo, é bastante conveniente para o cliente (que pode consumi-lo no melhor local e momento), tem uma ampla distribuição, pode ser bastante customizado pelos clientes e as empresas podem ter um rápido retorno sobre a satisfação do consumidor em relação ao serviço. Por outro lado, para que a transação ocorra a empresa depende da pró-atividade dos consumidores, que precisam ser ativos na busca de informações e na compra. Vale lembrar que no meio eletrônico há uma certa tendência de competição baseada em preços.

Em comparação à transação de bens, os canais de distribuição em serviços são mais diretos e curtos, segundo Boone e Kurtz (2006) e Oumlil e Rao (1993). Isso se deve principalmente à característica de intangibilidade dos serviços. Os profissionais que trabalham nessa área não têm preocupações quanto a onde estocar o serviço ou como transportá-lo. Esses autores apontam duas exceções em relação à distribuição de serviços, as quais denominam de consolidadores e franquias. Os consolidadores - também conhecidos como agentes ou corretores - são empresas ou lojas que vendem uma gama de serviços de diversas empresas, como, por exemplo, operadores de turismo que comercializam assentos de diversas empresas aéreas.

Lovelock e Wirtz (2006) não descartam a possibilidade de utilizar intermediários para distribuir os serviços, mas defendem que a tendência de distribuição direta ou de controle sobre a distribuição é muito maior em serviços do que em empresas que vendem bens.

Um dos fatores que conferem maior complexidade à proposta de Lovelock e Wirtz (2006) no que se refere à decisão sobre a variável distribuição em serviços é o fato de considerarem que deve ser feita sob dois aspectos: serviço central e serviços suplementares. Há certos tipos de serviços em que a localização é única, como, por exemplo, aqueles oferecidos por determinado hotel. Porém, já para os serviços suplementares, que ampliam e diversificam o serviço central, a distribuição não é única, visto que estão, em sua maior parte, relacionados com informações que podem ser passadas aos consumidores, efetivos ou potenciais, por telefone, fax, Internet, pessoalmente etc (LOVELOCK, WIRTZ, 2006). 
A entrega dos serviços pode ocorrer de três maneiras distintas de acordo com a classificação de Lovelock e Wirtz (2006). Há situações em que o cliente tem a necessidade de se dirigir até a organização para que o serviço possa acontecer (exemplos são cabeleireiros, aulas de dança, serviços de transporte). Para esses casos em que os serviços são distribuídos em locais físicos, há problemas de localização que devem ser estudados levando-se em consideração o comportamento do consumidor e a concorrência. Os avanços tecnológicos permitiram que muitos serviços passassem a ser distribuídos pela Internet ou ainda que esse canal fosse utilizado como um serviço facilitador.

Há também casos em que a organização de serviços vai até o consumidor. Existem empresas que têm desenvolvido essa estratégia de atuação, concentrando-se na entrega de serviços na casa do consumidor, destacando-se nesse caso a venda porta a porta, que, segundo Oumlil e Rao (1993), tem retomado seu crescimento. Exemplos de serviços que são entregues ou realizados na casa do consumidor são reparos residenciais, limpeza doméstica e aqueles prestados por jardineiros, babás e carteiros.

Por fim, há serviços em que cliente e empresa transacionam a distância, como transações financeiras ou de telefonia.

Lovelock e Wirtz (2006) propõem um método de entrega de serviços para orientar as empresas no processo de tomada de decisão, conforme mostra o Quadro 4.

Quadro 4 - Método de entrega de serviço.

\begin{tabular}{|l|l|l|}
\multicolumn{1}{|c|}{$\begin{array}{c}\text { Natureza da interação entre } \\
\text { cliente e organização de serviços }\end{array}$} & \multicolumn{1}{|c|}{ Disponibilidade em local único } & \multicolumn{1}{c|}{$\begin{array}{c}\text { Disponibilidade em vários } \\
\text { locais }\end{array}$} \\
\hline $\begin{array}{l}\text { Cliente vai até a organização de } \\
\text { serviços }\end{array}$ & $\begin{array}{l}\text { Teatro } \\
\text { barbearia }\end{array}$ & $\begin{array}{l}\text { Serviço de ônibus } \\
\text { Cadeia de fast food }\end{array}$ \\
\hline $\begin{array}{l}\text { A organização de serviços vai até } \\
\text { o cliente }\end{array}$ & $\begin{array}{l}\text { Pintar a casa } \\
\text { Lavar o carro }\end{array}$ & $\begin{array}{l}\text { Entregar correspondência } \\
\text { Serviço de socorro }\end{array}$ \\
\hline $\begin{array}{l}\text { Cliente e organização de serviços } \\
\text { transacionam a distância }\end{array}$ & Operadora de cartão de crédito & $\begin{array}{l}\text { Rede de notícias } \\
\text { Empresa telefônica }\end{array}$ \\
\hline
\end{tabular}

FONTE: Adaptado de LOVELOCK, WIRTZ, 2006, p.159.

No caso de serviços as empresas não podem pressupor que os clientes irão se dirigir até a loja para consumir o que está sendo ofertado. Na verdade, a preocupação de que o serviço está 
sendo oferecido no lugar certo e para as pessoas certas é mais constante nesse setor. Grönroos (2003) denomina isso como acessibilidade de serviço, que, segundo o autor, é um conceito mais importante que o de distribuição. A acessibilidade pode depender (GRÖNROOS, 2003):

- Do número e das habilidades do pessoal;

- Dos horários de trabalho, dos cronogramas e do tempo gasto para realizar diversas tarefas;

- Da localização dos escritórios, oficinas e/ou lojas de serviço;

- Do exterior e interior de escritórios, oficinas e outras lojas de serviço;

- Das ferramentas, dos equipamentos e/ou dos documentos;

- Da tecnologia de informação que habilite os clientes a obterem acesso ao prestador de serviços e ao processo de serviço;

- Do número e do conhecimento de consumidores simultaneamente envolvidos no processo.

Booms e Bitner (1982, apud MITTAL, BAKER, 1998) destacam também a importância da acessibilidade nas decisões relacionadas à distribuição de serviços, uma vez que em serviços distribui-se a capacidade de produzir, e não um produto. Portanto, a empresa de serviços deve ter uma gestão estratégica na escolha de seus intermediários e dos locais em que os serviços serão prestados.

Vale ressaltar que Reardon et al. (1996) constataram que os varejistas de serviços estão mais propensos a possuírem lojas menores, sendo que a importância de localizar-se em pontos de alto trafego tem também menor importância. Segundo o resultado de sua pesquisa, os profissionais de marketing de varejos de serviços têm menor propensão a utilizar a localização como um fator estratégico. Sendo assim, para as decisões relacionadas à distribuição em serviços é muito mais importante e estratégico avaliar os tipos e o número de canais e questões relacionadas a isso do que avaliar a localização das lojas.

A seguir, o Quadro 5 apresenta as principais questões a serem avaliadas e decididas no gerenciamento da distribuição em serviços. 
Quadro 5 - Resumo das principais decisões sobre distribuição em serviços.

\begin{tabular}{|l|l|}
\hline Considerações & Alternativas \\
\hline Como o serviço será entregue & $\begin{array}{l}\text { - Cliente vai a organização } \\
- \text { Organização vai até o cliente } \\
- \text { Cliente e organização realizam transação a distância }\end{array}$ \\
\hline Tipos de Canais & $\begin{array}{l}\text { - Quantidade de intermediários } \\
- \text { Estabelecimento único ou múltiplo }\end{array}$ \\
& $\begin{array}{l}\text { Tipos de canais e papéis: canais diretos, } \\
\text { intermediários ou canais eletrônicos } \\
\text { - Localização física da loja de serviços }\end{array}$ \\
\hline Outras decisões & $\begin{array}{l}\text { - Materiais e tecnologias envolvidas no processo } \\
\text { - Definição de papel de cada intermediário }\end{array}$ \\
\hline
\end{tabular}

FONTE: Elaborado com base em LOVELOCK, WRIGHT, 2001.

Na próxima seção discute-se outra variável que compõe o composto de marketing: produto.

\subsubsection{Produto}

A variável de decisão produto em marketing de serviços constitui-se de elementos variados, o que confere certa complexidade ao processo de tomada de decisão. Tal complexidade parte da própria natureza do produto, que é um serviço, fato esse derivado principalmente de sua característica principal, a intangibilidade.

Fitzsimmons e Fitzsimmons (2005) afirmam que os gerentes de marketing de serviços têm grande dificuldade de identificar seus produtos devido à sua natureza intangível. Ademais, McLean (1994) argumenta que em serviços o produto pode assumir papel diverso - uma experiência, aceitação social etc. -, o que depende fundamentalmente do ponto de vista do consumidor, como propriamente foi discutido no primeiro capítulo desta dissertação.

Segundo Bessom e Jackson (1975), o conceito de produto em serviços pode ser entendido como sendo composto de um serviço central (motivo pelo qual o consumidor adquire o serviço) e de um mix de serviços auxiliares determinados pela demanda do mercado e por aquilo que o ofertante tem capacidade de oferecer. Esses autores sustentam que o $\mathrm{P}$ de elementos físicos e o P de pessoas do composto de marketing expandido fazem parte dos 
elementos tangíveis do P de produto, ou seja, da oferta de serviços. Segundo eles, “[...] os serviços devem ser bons, mas devem parecer bons" (p.81).

Kotler e Bloom (1984), na mesma linha, sugerem que o produto em serviços seja entendido mediante três níveis distintos: núcleo, perceptível e aumentado. Em relação ao núcleo, surgem as seguintes questões: $\mathrm{O}$ que o cliente está realmente procurando? A que necessidade o serviço está realmente satisfazendo? Segundo Kotler e Bloom (1984), o profissional de marketing deve descobrir as necessidades essenciais do cliente, para que os benefícios do serviço - e não apenas suas características - possam ser potencializados e expressos na comunicação com o consumidor.

O serviço-núcleo está sempre à disposição do cliente, sendo de alguma forma perceptível. De acordo com Kotler e Bloom (1984, p.198), são seis os atributos básicos de um serviço que os clientes percebem e, em geral, procuram avaliar, no intuito de verificar se são capazes de satisfazer os benefícios-núcleo que estão procurando. São eles:

- Pessoal: as pessoas que executam o serviço. As pessoas que fornecem um serviço são o atributo-chave daquele serviço. Em certos tipos de serviços, os consumidores compram "pessoas" em lugar de serviços, o que é instigante para os efeitos e ações de marketing. O desenvolvimento de forte atributo "pessoal" exige treinamento, aprendizagem e mobilidade dos profissionais, já que são a referência maior para os clientes.

- Nível de qualidade: o nível de competência profissional com que o serviço é executado. Implica monitoramento constante dos níveis de qualidade e rigorosa disciplina para mantêlos. Pesquisas com clientes podem esclarecer como são avaliados os níveis de qualidade, sugerindo áreas em que se faz necessário implantar refinamentos no serviço ou melhor comunicação nos atuais níveis de qualidade.

- Duração do serviço: o tempo necessário para a execução do serviço (tempo vendável) pode ter grande influência na avaliação feita pelos clientes.

- Tempo de espera: o tempo que o cliente tem de esperar antes que o serviço seja satisfatoriamente completado. Quanto menos os clientes têm de esperar para começar a receber um serviço, mais o apreciam. 
- Equipamento de suporte: a maquinaria, os instrumentos e outros equipamentos que o profissional utiliza para realizar o serviço. Os clientes formam impressões dos profissionais baseando-se em parte nos tipos de computadores, instrumentos e equipamentos utilizados, podendo-se mensurar, por meio de pesquisa, o quanto os clientes do mercado-alvo atentam para esse fator.

- Pacote e rotulagem: o nome e a respectiva descrição do serviço ou do conjunto de serviços. A oferta de "pacotes", com marcas apropriadas, diferencia os serviços ante os olhos dos clientes e também os ajuda a lembrar deles.

Além disso, pode-se oferecer ao mercado serviços e benefícios extras, configurando um serviço aumentado. O aumento do nível do serviço, ultrapassando as condições perceptíveis, visa a atender aos desejos adicionais dos clientes e/ou diferenciar seus serviços da concorrência. Nessa proposta, os autores também defendem que pessoas, elementos físicos e processos fazem parte do conjunto de decisões de produto.

Fitzsimmons e Fitzsimmons (2005), por sua vez, apresentam uma proposta de pacote de serviços que é composto dos seguintes elementos:

- Instalações de apoio: são os recursos físicos que devem estar disponíveis antes do início da prestação de serviços. Quartos de hotel, por exemplo.

- Bens facilitadores: são também recursos físicos que serão consumidos no momento da prestação de serviços. Alimentos, suprimentos médicos.

- Informações: dados da operação da empresa ou informações fornecidas pelo consumidor para tornar a prestação de serviços eficiente e até customizada. Disponibilidade de vagas, informações anteriores de compra etc.

- Serviços explícitos: benefícios percebidos pelos clientes imediatamente após a prestação de serviços. Automóvel funcionando perfeitamente após o reparo, por exemplo.

- Serviços implícitos: benefícios psicológicos ou características extrínsecas aos serviços, tal como saber que está tendo aula com um professor da melhor universidade do país.

Essa proposta leva em consideração a perspectiva do consumidor e suas expectativas em relação ao serviço. No entanto, do ponto de vista gerencial é uma proposta pouco prática, pois não auxilia no processo de tomada de decisão, já que é uma abordagem subjetiva e pouco concreta da realidade. 
Lovelock e Wirtz (2006) propõem que os serviços sejam entendidos a partir de duas perspectivas: a dos aspectos principais dos serviços; e outra dos serviços agregados. Deve-se atentar para todos os aspectos de desempenho que tenham potencial para criar valor ao cliente. Nesse sentido, os autores introduziram o conceito da Flor de Serviços, que mostra que muitas vezes serviços centrais diferentes podem compartilhar dos mesmos serviços complementares. Sendo assim, os autores sustentam que a tomada de decisão sobre produto no marketing mix deve também considerar a definição do produto ampliado, por meio do qual a empresa pode estabelecer vantagens competitivas, e sugerem que os gestores abordem três componentes fundamentais:

- Produto principal: refere-se ao motivo de existência da empresa e ao motivo principal da aquisição dos serviços. O produto principal satisfaz a necessidade principal do consumidor.

- Serviços suplementares: os serviços suplementares ampliam a utilização do serviço principal e são características diferenciadoras que auxiliam no posicionamento do produto principal. Os serviços suplementares elevam o nível de desempenho do serviço principal, possibilitando que a empresa cobre preços mais elevados.

- Processo de entrega: a decisão sobre o produto deve também considerar como os serviços serão entregues ao consumidor e qual será o nível de participação dos consumidores no processo de produção dos serviços.

Além disso, Lovelock e Wirtz (2006) propõem a classificação dos serviços suplementares, responsáveis pela efetiva ampliação do produto principal, em dois grandes grupos: os facilitadores e os realçadores. A maior parte dos serviços possui serviços suplementares que podem ser classificados dessa forma, independentemente do serviço principal. O Quadro 6 apresenta um resumo dos principais serviços facilitadores e realçadores. 
Quadro 6 - Descrição dos serviços suplementares.

\begin{tabular}{|c|c|c|}
\hline Serviços suplementares & Descrição & Tipo \\
\hline Informação & $\begin{array}{l}\text { Grande parte desse serviço concentra-se na pré-compra. } \\
\text { Informações de preços, localização e condições de venda, } \\
\text { por exemplo, fazem parte desse serviço facilitador. Não } \\
\text { menos importantes são informações de confirmação de } \\
\text { reserva, extratos e outras documentações. }\end{array}$ & facilitador \\
\hline Recebimento de pedidos & $\begin{array}{l}\text { Decidida a compra pelo consumidor, é importante que a } \\
\text { empresa tenha uma estrutura ágil de inscrições, pedidos e } \\
\text { reservas. }\end{array}$ & facilitador \\
\hline Cobrança & $\begin{array}{l}\text { Procedimentos para a efetuação da cobrança do serviço } \\
\text { prestado. }\end{array}$ & facilitador \\
\hline Pagamento & $\begin{array}{l}\text { Atividades exercidas pela empresa que podem facilitar o } \\
\text { processo de pagamento, como, por exemplo, } \\
\text { disponibilidade de troco, transferências eletrônicas, } \\
\text { cartões, entre outros. }\end{array}$ & facilitador \\
\hline Consulta & $\begin{array}{l}\text { Refere-se à atividade de sondar o cliente para que a } \\
\text { empresa lhe ofereça uma solução mais adequada. }\end{array}$ & Realçador \\
\hline Hospitalidade & $\begin{array}{l}\text { Maneira como o cliente será recebido pela empresa de } \\
\text { serviços. Cumprimentos, comidas, bebidas, instalações, } \\
\text { transporte e segurança fazem parte deste serviço. }\end{array}$ & Realçador \\
\hline Salvaguarda & $\begin{array}{l}\text { São serviços relacionados a cuidados com os clientes. } \\
\text { Exemplos são serviços de chapelaria, para crianças e } \\
\text { animais de estimação, manobristas, cofres, limpeza, } \\
\text { atualização, consertos, manutenção preventiva etc. }\end{array}$ & Realçador \\
\hline Exceções & $\begin{array}{l}\text { São serviços que não fazem parte da rotina da empresa } \\
\text { prestadora de serviços. Esses serviços demonstram a } \\
\text { flexibilidade da empresa em resolver problemas } \\
\text { inesperados, em atender a solicitações especiais e até } \\
\text { mesmo a maneira como lidam com as reclamações dos } \\
\text { clientes. }\end{array}$ & Realçador \\
\hline
\end{tabular}

FONTE: Elaborado com base em LOVELOCK, WIRTZ, 2006. 
Cada um dos tipos de serviços facilitadores ou realçadores dão origem ao que Lovelock, em 1992, denominou de A Flor de Serviços, sendo que o miolo da Flor seria o produto principal e as pétalas seriam os tipos de serviços (oito no total), conforme ilustra a Figura 8. A metáfora da flor utilizada pelo autor traduz a delicadeza necessária no gerenciamento dos serviços e, ao mesmo tempo, denota que todas as pétalas são importantes, posto que os consumidores obviamente preferem flores inteiras a flores despetaladas.

Figura 8- A Flor de Serviços: produto principal cercado por grupos de serviços suplementares.

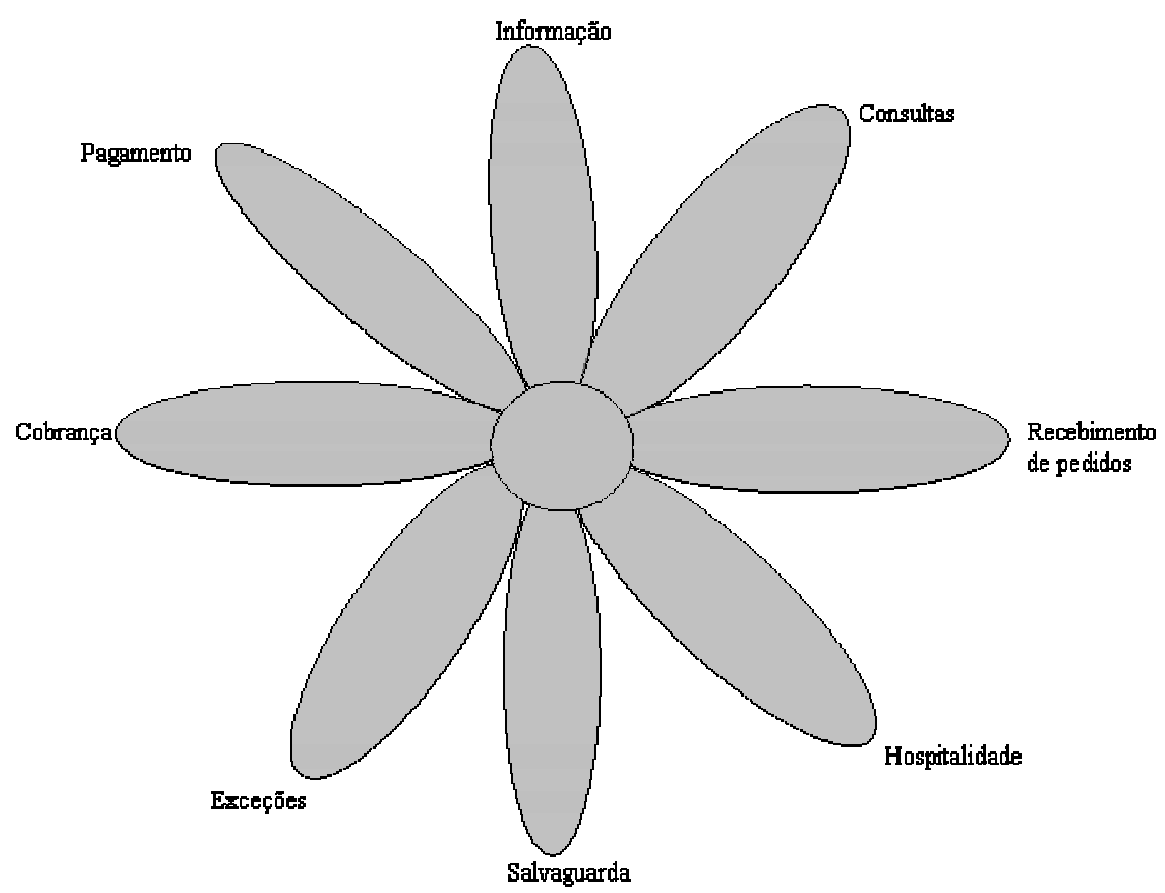

FONTE: LOVELOCK, WIRTZ, 2006, p.84.

Como já referido anteriormente, as decisões de processos, pessoas e elementos físicos podem ser entendidas como subitens da decisão de produto. As propostas de Kotler e Bloom (1984), Lovelock e Wirtz (2006) e Bessom e Jackson (1975) incorporam essas variáveis na decisão de produto.

A operação ou, no caso, o processo abrange aspectos que constituem o produto, pois proporcionam o benefício ao consumidor por meio da experiência interativa. Dessa forma, o marketing de serviços tem um problema adicional em relação ao marketing de bens, pois é 
mais difícil ter um bom ajuste entre eficiência de operações e eficácia de marketing. Como o produto de serviços é uma experiência, criada pelo sistema de operações da empresa e sua interação com o cliente, pode-se dizer que o sistema operacional e sua complexidade constituem o P de produto em serviços (HOFFMAN, BATESON, 2003).

Lovelock e Wirtz (2006) afirmam que "[...] processos são a arquitetura de serviços e descrevem o método e a seqüência em que funcionam sistemas operacionais de serviços e como eles se interligam para criar experiências e os resultados de serviços que os clientes valorizarão" (p.187).

O que é um serviço se não uma seqüência de atividades inter-relacionadas que propiciarão um benefício ao consumidor? A definição daquilo que Lovelock e Wirtz (2006) denominam de "esquema de serviços" é inerente ao produto em marketing de serviços, e por esse motivo está sendo considerado nesta dissertação como parte integrante da decisão de produto.

Para McLean (1994), o processo de entrega dos serviços ao consumidor é fundamental. Tal preocupação deriva da variabilidade dos serviços e das interações sociais existentes no processo. Nenhum consumidor é igual ao outro e os funcionários não atuam igualmente entre si.

Em se tratando da definição de produto em serviços, ao que Lovelock (1996) confere a denominação de product design, se faz necessário especificar o papel dos consumidores no processo de prestação de serviços, além de definir as características físicas, os equipamentos e os funcionários necessários. Essa definição é importante porque a maior parte das empresas busca diminuir custos e melhorar a produtividade mediante o ciclo curto de atendimento quanto mais rápido atender um cliente, mais clientes poderá atender. Para tanto, é necessário que a empresa desenhe um fluxo de processos aperfeiçoado, conhecido como blueprinting, que considera toda e qualquer atividade necessária para entregar o serviço e também especifica a ligação entre elas.

Shostack (1977) destaca que o blueprinting deve relacionar o desempenho de cada atividade com o tempo, além de identificar possíveis erros, restrições e reiterações. Ademais, com base na experiência, deve apontar as possíveis variações em relação ao padrão (o que ajudará as empresas a atingir a meta, quase unânime, de operação de ciclo curto). Entende-se, portanto, 
que clientes e funcionários, ou seja, pessoas, estão intimamente relacionados com o processo e, assim, com a decisão de produto.

Para o serviço, que é essencialmente intangível, os elementos físicos são necessários não só para ajudar a criar uma imagem da empresa prestadora de serviços na cabeça de seu públicoalvo (McLEAN 1994), como também para tangibilizar ou complementar o serviço central que está sendo ofertado. Lovelock e Wirtz (2006, p.236) afirmam que o "[...] ambiente físico de serviço tem um importante papel na modelagem da experiência de serviços e na satisfação do cliente $[\ldots] "$.

O ambiente físico também tem o importante papel de projetar uma imagem da organização na mente do consumidor. Essa é a evidência mais forte que a empresa pode utilizar para tangibilizar seu serviço. Por meio do ambiente físico, local em que muitas vezes o consumidor irá ter a experiência do serviço, a empresa pode passar a imagem que deseja e ainda, de certa forma, dar sinais da qualidade que o cliente irá encontrar.

Do ponto de vista gerencial, a empresa pode atuar em algumas dimensões, que, conforme sugerem Lovelock e Wirtz (2006, adaptação feita à proposta de Berman e Evans, 2001), são:

- Instalações exteriores: referem-se a todas as características externas da loja, como fachada, vitrine, gramados, disposição do estacionamento e, ainda, lojas da vizinhança.

- Interior geral: está relacionado com a decoração do ambiente interno da loja/ estabelecimento, incluindo a disposição da comunicação de preços, sinalizações, escadas etc.

- Disposição da loja: refere-se à organização do interior da loja, ou seja, locais de venda, espera, posicionamento de mercadorias, localização dos departamentos, entre outros.

- Expositores internos: refere-se a itens utilizados para a exposição daquilo que está sendo vendido, como estantes, expositores, elementos decorativos, ambiente temático etc.

- Dimensões sociais: englobam uniformes dos funcionários, privacidades, auto-serviço etc.

A seguir, o Quadro 7 apresenta os principais elementos físicos a serem considerados, de acordo com Zeithaml e Bitner (2003). 
Quadro 7 - Elementos de evidência física.

\begin{tabular}{|ll|}
\hline Cenário de serviços & Outros tangíveis \\
\hline - Instalações exteriores & Cartões de visita \\
arquitetura externa & Itens de papelaria \\
sinalização & Documentos de cobrança \\
estacionamento & Relatórios \\
paisagem & Roupas de funcionários \\
ambiente de entorno & Uniformes \\
& Material impresso \\
- Instalações interiores & Páginas na internet \\
arquitetura interna & \\
equipamentos & \\
sinalização & \\
leiaute & \\
qualidade do ar/temperatura & \\
\end{tabular}

FONTE: ZEITHAML, BITNER, 2003, p.233.

A elaboração do esquema de serviços consiste, portanto, na definição da seqüência dos acontecimentos no processo de prestação de serviços, incluindo a participação de funcionários, máquinas e equipamentos, bem como a determinação do papel do cliente. A elaboração desse esquema, que é particular para cada empresa, propicia a identificação de possíveis momentos de falha, o que habilita a organização a estabelecer outros procedimentos para evitar que eles aconteçam e levem à insatisfação do consumidor.

Outras dimensões de pessoas e elementos físicos serão comentadas na abordagem sobre comunicação, variável de decisão que será discutida no próximo subitem.

\subsubsection{Comunicação}

Da mesma maneira que o marketing foi inicialmente desenvolvido para empresas de bens de massa, as estratégias de comunicação tradicionais foram modeladas para fazer a promoção desse tipo de produto. Entretanto, as diferenças fundamentais entre bens e serviços tornam necessária uma abordagem distinta da comunicação em empresas de serviços (LOVELOCK, WIRTZ, 2006). 
As decisões que envolvem a variável promoção referem-se à comunicação do serviço e, de acordo com Hoffman e Bateson (2003), devem levar em consideração o público interno e externo à organização. Para Lovelock e Wright (2001), os objetivos principais da comunicação são:

- Informar e conscientizar os clientes atuais e potenciais sobre a empresa e as características dos bens e/ou serviços oferecidos por ela;

- Persuadir os clientes potenciais;

- Lembrar os clientes sobre a empresa e sobre aquilo que ela oferta;

- Manter contato com clientes.

Essencialmente, a comunicação em marketing de serviços toma a mesma forma que em marketing de bens. Em primeiro lugar, a demanda deve ser estimulada por meio de propaganda e promoção de vendas que comuniquem os benefícios que serão levados ao consumidor. Uma atuação mais focada de comunicação de marketing informa os benefícios e diferenciais dos serviços ofertados pela empresa em relação à concorrência, no entanto um esforço maior é necessário para diminuir a dissonância cognitiva - ou arrependimento póscompra - do consumidor, que, em geral, em serviços é maior que na compra de bens (BLACKWELL et al., 2005).

Para Kotler e Bloom (1984), a comunicação de um serviço abarca um elemento especial, que é o contato direto com o consumidor, a fim de persuadi-lo a comprar ou contratar o serviço. Eles defendem que é preciso desenvolver a habilidade do contato pessoal em vez de persuadir por meio de mídias de massa. Conforme alertam os autores, deve-se lembrar que existem alguns tipos de serviços que não podem ser anunciados devido a regras e legislações dos países.

Os objetivos da comunicação podem ser alcançados mediante a utilização de um mix de comunicação adequado, ou seja, empregando-se uma combinação apropriada das ferramentas disponíveis, tais como comunicação pessoal, propaganda, promoção, publicidade, relações públicas e design empresarial. A seguir, o Quadro 8 faz um breve resumo das principais ferramentas disponíveis no mix de comunicação. A última ferramenta apresentada, o design empresarial, é comumente utilizada para a comunicação de serviços. 
Quadro 8 - Principais ferramentas do mix de comunicação.

\begin{tabular}{|c|c|c|}
\hline FERRAMENTA & & CARACTERÍSTICA \\
\hline $\begin{array}{l}\text { Comunicações } \\
\text { Pessoais }\end{array}$ & $\begin{array}{l}\text { Vendas } \\
\text { Atendimento ao cliente } \\
\text { Treinamento } \\
\text { Boca a boca }\end{array}$ & $\begin{array}{l}\text { Comunicação personalizada, interativa e modular. É a } \\
\text { forma mais persuasiva de comunicação. }\end{array}$ \\
\hline Propaganda & $\begin{array}{l}\text { Rádio, televisão } \\
\text { Imprensa escrita } \\
\text { Internet } \\
\text { Outdoors } \\
\text { Displays de varejo } \\
\text { Cinema, Teatro } \\
\text { Mala Direta, Telemarketing }\end{array}$ & $\begin{array}{l}\text { A principal função da propaganda é criar imagem para } \\
\text { o produto ou marca que possa transmitir o } \\
\text { posicionamento desejado junto ao público-alvo. }\end{array}$ \\
\hline Promoção & $\begin{array}{l}\text { Amostras } \\
\text { Cupons } \\
\text { Descontos } \\
\text { Abatimentos em taxas de adesão } \\
\text { Brindes } \\
\text { Promoções }\end{array}$ & $\begin{array}{l}\text { A função da promoção é estimular a venda do produto, } \\
\text { por meio da oferta de algum tipo de benefício extra e } \\
\text { temporário agregado ao produto. }\end{array}$ \\
\hline Publicidade & & $\begin{array}{l}\text { Sua função é similar à da propaganda, mas com a } \\
\text { diferença de que sua veiculação não é paga. }\end{array}$ \\
\hline Relações Públicas & $\begin{array}{l}\text { Press releases } \\
\text { Patrocínios }\end{array}$ & $\begin{array}{l}\text { A prioridade das ações de relações públicas é manter a } \\
\text { boa imagem da empresa junto à comunidade (opinião } \\
\text { pública). }\end{array}$ \\
\hline Design Empresarial & $\begin{array}{l}\text { Simbologia } \\
\text { Decoração interna } \\
\text { Veículos } \\
\text { Equipamento } \\
\text { Papel timbrado } \\
\text { Uniformes }\end{array}$ & $\begin{array}{l}\text { Desenvolvimento de uma imagem corporativa em } \\
\text { materiais tangíveis. }\end{array}$ \\
\hline
\end{tabular}

FONTE: Elaborado com base em KOTLER, KELLER, 2005; NICKELS, WOOD, 1999; SCHULTZ, BARNES, 2001; SHIMP, 2002; LOVELOCK, WRIGHT, 2001; e HOFFMAN, BATESON, 2003.

Lovelock e Wirtz (2006) destacam alguns pontos que diferenciam a comunicação dos serviços da comunicação de bens. Em primeiro lugar, sugerem que as empresas de serviços superem os problemas de intangibilidade. Em relação à grande preocupação de se tangibilizar o 
intangível, Legg e Baker (1987) destacam que além de os serviços não poderem ser tocados, há dificuldade para concretizá-los na mente do consumidor. Assim, para superar essa questão em marketing de serviços, defendem três estratégias principais: a utilização de objetos tangíveis, a utilização de linguagem concreta e a dramatização.

A utilização de objetos tangíveis pode levar o consumidor a transferir seu significado para o serviço. Uma empresa de seguros, por exemplo, pode usar em sua comunicação guardachuvas e casacos num dia de frio, que fazem o consumidor lembrar-se de proteção. Já a linguagem concreta se faz necessária porque o uso de palavras vagas e muito abrangentes na comunicação de um serviço não ajuda o consumidor a defini-lo ou associá-lo a algo mais tangível. Ademais, a adjetivação nas comunicações de serviços pode ser perigosa. Por fim, a dramatização refere-se à utilização de cenas imitando a realidade, a fim de demonstrar os benefícios que um serviço pode trazer - o que também ajuda o consumidor a concretizar o serviço em sua mente. Lovelock e Wirtz (2006) compartilham da mesma opinião.

Em contrapartida, Las Casas (2000) defende que é possível contornar o problema da intangibilidade enfatizando-se os benefícios do serviço e a imagem corporativa:

\footnotetext{
Tangíveis ou intangíveis, a ênfase na divulgação dos serviços deve ser sempre no benefício que proporciona. Alguns serviços prestados a consumidores finais são individualistas no sentido de que o produto varia de acordo com a necessidade de cada cliente. Por isso, na comunicação há necessidade de se formar uma imagem da empresa, pois a forma pela qual o consumidor a visualiza no momento da necessidade de consumo é determinada pela informação e conceito adquiridos. (LAS
} CASAS, 2000, p.127)

Em segundo lugar, Lovelock e Wirtz (2006) sugerem que a comunicação para serviços vise a facilitar o envolvimento do cliente na produção do serviço, oferecendo informações relevantes sobre ele, os riscos envolvidos e como diminuí-los. Em terceiro lugar, os autores propõem que, por meio da comunicação de marketing, as empresas ajudem os clientes a avaliar a oferta de serviços, dando informações para que possam comparar as diversas propostas do mercado. Outra possibilidade importante da comunicação é utilizá-la para ajustar possíveis diferenças entre a demanda e a capacidade de oferta da empresa, reduzindo-a em momentos de pico e aumentando-a em momentos de pouca demanda. Por fim, Lovelock e Wirtz (2006) sugerem 
promover o pessoal de serviços, ou seja, a expertise e cordialidade dos funcionários, de maneira a moldá-los de acordo com as expectativas dos consumidores.

Bessom e Jackson (1975) destacam a importância de a empresa de serviços trabalhar fortemente a ferramenta de relações públicas, a fim de manter uma imagem corporativa positiva, garantindo a sua aceitação pela comunidade em que está inserida.

Já Hoffman e Bateson (2003) enfatizam a relevância da comunicação de serviços para o público-alvo correto, argumentando que a influência do cliente na produção do serviço é muito ampla. As comunicações mal direcionadas, conforme afirmam, podem tornar desagradáveis as experiências com o serviço. Os autores dão como exemplo o caso de um restaurante chique para pessoas de meia-idade. Se a agência de propaganda faz uma comunicação com foco em preço, por exemplo, o público atraído será, provavelmente, diferente do original, o que trará impactos para o momento da prestação do serviço.

Hoffman e Bateson (2003) ainda apontam que na comunicação de serviços o gerenciamento da expectativa do cliente é importante. Se na propaganda os funcionários são amigáveis e bonitos, os consumidores esperarão encontrar o mesmo no momento da prestação de serviços. Ademais, o entendimento dos processos de atendimento pelo departamento de marketing é importante para que não sejam feitas promessas que não possam ser cumpridas. Os temas mais comuns de comunicação utilizados pelas empresas de serviços são, segundo Boone e Kurtz (2006), eficiência, expertise, status e cordialidade.

Las Casas (2000), por sua vez, destaca a preocupação quanto à construção de marca para o serviço ou a empresa prestadora de serviço. Segundo a American Marketing Associtation (AMA), marca é:

\footnotetext{
Um nome, termo, design, símbolo, ou qualquer outra característica que identifica um bem ou serviço que está sendo vendido para distinguir da oferta de outro [...]. Uma marca identifica um item ou uma família de itens ou todos os itens que o ofertante vende [...]. (AMA, 2008)
}

As marcas no setor de serviços podem desempenhar um papel importante na definição da posição competitiva de uma empresa no mercado (LOVELOCK, WRIGHT, 2001). Em 
serviços a marca não apenas representa o nome ou o símbolo de uma empresa, conforme expõe a definição da AMA, mas também é uma promessa de certo nível de desempenho. Isso acontece principalmente porque a oferta de serviços raramente oferece uma garantia ao cliente. Para exemplificar essa questão pode-se pensar no diagnóstico de um médico - qual a garantia de que o diagnóstico dado por ele é o correto?

Grönroos (2004) também defende que o gerenciamento da imagem e da comunicação é parte integral do desenvolvimento de ofertas de serviços. Como o serviço é intangível, a comunicação impacta não apenas as expectativas dos clientes, como também a própria experiência de consumo.

Zeithaml e Bitner (2003) argumentam que o comprometimento do consumidor com as marcas está associado a fatores como:

- custo de mudar de marca;

- disponibilidade de marcas substitutas;

- risco percebido associado à compra;

- nível de satisfação obtido em transações anteriores.

Mudar de marca em serviços costuma ser mais custoso, segundo esses autores, posto que nem sempre substitutos são facilmente encontrados, requerendo investimento de tempo e dinheiro por parte do consumidor. Além disso, os riscos associados em transações de serviços são mais elevados, devido ao envolvimento do consumidor no processo de produção. Em geral, a compra repetida de determinados tipos de serviços, como aqueles prestados por cabeleireiros, advogados, dentistas, entre outros, permite um maior conhecimento do atendente (ou empresa) sobre os gostos e preferências do consumidor, o que o motiva a permanecer cliente de determinada marca ou estabelecimento de serviços.

A seguir, destacam-se as oito funções que a marca, de acordo com Kapferer (2003), pode assumir para o consumidor. Nota-se que as duas primeiras são de caráter mecânico, ou seja, dizem respeito à essência da marca. Por sua vez, garantia, otimização e personalização são funções que reduzem o risco percebido do consumidor. Já as funções de permanência, hedonista e ética são de natureza mais hedonista, refletindo o que o consumidor espera da marca, como, por exemplo, comportamento responsável. 
Quadro 9 - As funções da marca para o consumidor.

\begin{tabular}{|c|c|}
\hline Função & Benefício ao consumidor \\
\hline De referência & $\begin{array}{l}\text { Ver claramente, situar-se em relação à produção setorial, identificar rapidamente os } \\
\text { produtos procurados. }\end{array}$ \\
\hline De praticidade & $\begin{array}{l}\text { Permitir ganho de tempo e de energia na recompra de produtos idênticos pela } \\
\text { fidelidade. }\end{array}$ \\
\hline De garantia & Segurança de encontrar uma qualidade estável em todos os lugares e a todo instante. \\
\hline De otimização & $\begin{array}{l}\text { Segurança de comprar o melhor produto de sua categoria, com o melhor desempenho } \\
\text { para o uso específico. }\end{array}$ \\
\hline De personalização & $\begin{array}{l}\text { Sentir-se reconfortado com sua auto-imagem ou com a imagem que é passada aos } \\
\text { outros. }\end{array}$ \\
\hline De permanência & $\begin{array}{l}\text { Satisfação nascida da familiaridade e da intimidade das ligações com uma marca que } \\
\text { foi consumida durante anos e que ainda dura. }\end{array}$ \\
\hline Hedonista & Satisfação ligada à estética da marca, seu design e suas comunicações. \\
\hline Ética & $\begin{array}{l}\text { Satisfação ligada ao comportamento responsável da marca nas suas relações com a } \\
\text { sociedade (ecologia, emprego, cidadania, publicidade não chocante. }\end{array}$ \\
\hline
\end{tabular}

FONTE: KAPFERER, 2003, p.24.

A construção de marca em serviços, no entanto, ainda está em processo de iniciação, visto que, de forma geral, os consumidores a reconhecem muito mais como uma razão social do que propriamente como uma marca. A marca em serviços é diferente da marca em bens devido à sua característica de invisibilidade. Em vista dessa característica, as empresas não conseguem mostrar sua oferta em suas comunicações, e por isso utilizam consumidores e funcionários nas campanhas. Além disso, utilizam slogans, que representam a vocação da marca, ou seja, definem seus parâmetros comportamentais. A variabilidade também é outro desafio da marca em serviços (KAPFERER, 2003).

Tendo em vista essas características dos serviços, a comunicação boca a boca no momento da compra e do consumo tem efeitos imediatos e também de longo prazo, afetando a percepção da qualidade dos serviços. Como muitos serviços são caracterizados por um relacionamento 
contínuo com os clientes, a comunicação boca a boca passa a ter um papel central para esse tipo de oferta, já que as pessoas atribuem maior credibilidade a essa modalidade de mensagem (GRÖNROOS, 2004).

Nesse sentido, Ikeda (1997) realizou uma pesquisa exploratória sobre a importância da comunicação boca a boca no processo de decisão de compra de serviços, ratificando a sua importância, seja feita por meio de parentes, amigos ou especialistas. Não é uma ferramenta que pode ser controlada, no entanto pode ser monitorada.

Destarte, por meio da consulta às obras de Hoffman e Bateson (2003), Zeithaml e Bitner (2003) e Grönroos (2003), pode-se depreender que as principais diretrizes gerais para o desenvolvimento da promoção em serviços são:

- Desenvolvimento da comunicação boca a boca: considerada um dos meios de comunicação mais eficaz, a comunicação boca a boca positiva também torna o cliente potencial mais receptivo às comunicações planejadas da empresa. A utilização de testemunhos nas campanhas de comunicação faz parte das sugestões desses autores.

- Prometer aquilo que é possível cumprir: essa diretriz relaciona-se diretamente com a satisfação geral do consumidor; sendo assim, a comunicação de marketing precisa se assegurar de que apenas promete aquilo que a empresa poderá cumprir.

- Tornar tangível o intangível: fornecer elementos tangíveis para que o serviço, essencialmente intangível, possa ser materializado pelo consumidor e, assim, facilmente lembrado.

- Deixar claro o relacionamento de trabalho entre cliente e provedor de serviços.

- Reduzir os temores do consumidor em relação à variabilidade da prestação de serviços.

- Ressaltar as dimensões relevantes de qualidade.

- Diferenciar por meio do processo de prestação de serviços.

- Promover o entendimento do processo de serviços para gerenciar as expectativas dos clientes mais facilmente.

- Comunicação direta para funcionários: os funcionários devem ser considerados como o segundo público-alvo da empresa, já que seu desempenho no processo de serviços é importante. Utilizá-los como personagens da comunicação externa é uma maneira de motiválos e de transmitir credibilidade aos clientes. 
- Consciência quanto à ausência de comunicação: essa diretriz deve ser levada em consideração principalmente em momentos de estresse na relação empresa - cliente. A falta de comunicação leva o cliente a supor a falta de controle da situação por parte da empresa, denegrindo sua imagem.

Assim, contata-se que o composto de comunicação em serviços contém as mesmas ferramentas do composto de comunicação de bens. Requer, no entanto, maior ou menor emprego de cada uma delas para melhor atingir resultados no cenário competitivo, sempre considerando aspectos peculiares aos serviços, conforme se verificou ao longo da seção.

Na sequiência, serão discutidos os serviços de demanda não desejada, tipo de serviço em que se pretende investigar o emprego das variáveis controláveis de marketing. A seção procurará definir o termo e abordar suas particularidades.

\subsection{Serviços de demanda não desejada}

Do ponto de vista da economia, de acordo com Pindyck e Rubinfeld (1999), a demanda pode ser definida como "[...] a quantidade do bem ou serviço que os consumidores desejam comprar para cada preço unitário que tenham que pagar”. Vale ressaltar que a expressão "desejam comprar" foi utilizada pelos autores, devendo ser interpretada como "efetivamente compram". Ou seja, a demanda é a quantidade de bem ou serviço efetivamente comprada pelos consumidores.

De acordo com Mansfield e Yohe (2006), alguns determinantes impactam a quantidade demandada pelos consumidores. Embora os determinantes de demanda sejam infinitos, podem-se citar como exemplos:

- Gostos ou preferências do consumidor;

- Renda disponível do consumidor;

- Preço do bem ou serviço;

- Preço de outros bens ou serviços.

Sob essa óptica, a variável preço talvez seja a mais evidente determinante da demanda. Sendo assim, a curva de demanda sempre é apresentada como sendo uma relação inversa entre preço 
versus quantidade (considerando-se todos os demais fatores constantes), ou seja, a curva de demanda negativamente inclinada sugere que os compradores tendem a diminuir a quantidade demandada a preços mais elevados (VASCONCELLOS, OLIVEIRA, 2000). Essa relação inversa é intuitiva e se explica por dois fatores: em primeiro lugar, preços maiores reduzem a renda disponível do consumidor, diminuindo assim a quantidade adquirida; em segundo lugar, a maior parte dos produtos possui um substituto mais ou menos perfeito. Sendo assim, o consumidor estaria substituindo o produto mais caro por outro mais acessível.

Porém, de acordo com Vasconcellos e Oliveira (2000), as preferências do consumidor também podem ser representadas por números. Os consumidores tentam sempre maximizar sua satisfação, o que em economia é denominado utilidade; ou seja, utilidade é o nível de satisfação que uma pessoa obtém ao consumir um bem ou serviço (PINDYCK, RUBINFELD, 1999). De forma mais clara, Simonsen (1967, p.8) define: "A posse de determinadas quantidades de bens, num certo período de tempo, proporciona ao indivíduo um certo grau de satisfação denominado utilidade."

A definição de demanda sob o ponto de vista do marketing segue as mesmas diretrizes da sua conceituação no âmbito da economia. Kotler e Keller (2005) acrescentam ainda que a demanda de mercado não é um número fixo, pois depende daquilo que denominam de condições determinadas, também chamadas de determinantes da demanda, termo já descrito anteriormente. A diferença, entretanto, é que em marketing o nível de despesas é um fator que também determina a demanda de mercado.

No que se refere ao nível de despesas com marketing - como fator determinante da demanda, encontra-se na literatura aquilo que pode ser chamado de "Curva em S". Nesse sentido, Lambin (1967) discute a relação entre os investimentos em marketing (somente aqueles relacionados diretamente com vendas) e a curva de demanda. $\mathrm{O}$ autor investiga o tipo de relação existente entre os investimentos em marketing e as quantidades demandadas, conforme expressa a Figura 9. Vale destacar que Lambin (1967) chama de investimentos de marketing não só aqueles que estão unicamente orientados para o consumidor final, como também aqueles direcionados para os atacadistas e varejistas. 
Figura 9 - Curva em S.

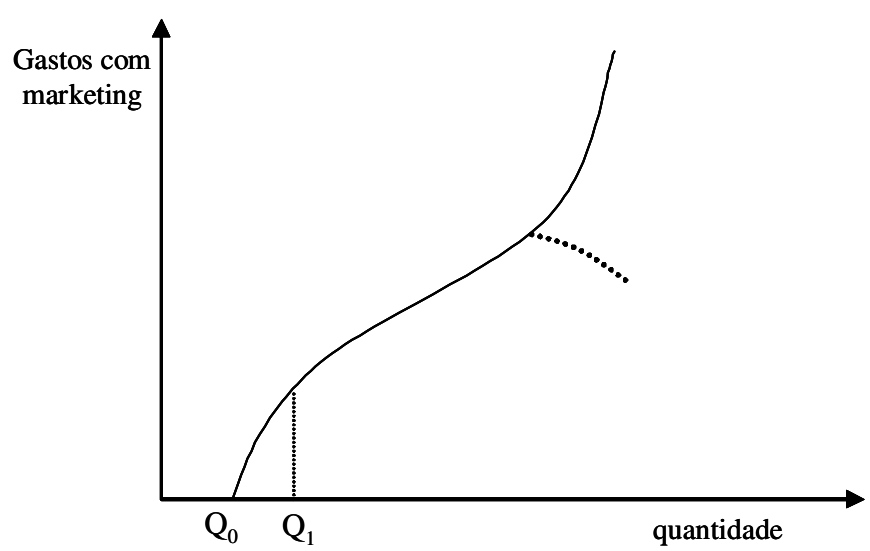

FONTE: Adaptado de LAMBIN, 1967, p.121.

Assim sendo, observa-se que sem investimentos em marketing a empresa tem uma certa quantidade demandada, sendo que para vender mais necessita aplicar recursos nesse âmbito. Os investimentos iniciais em marketing não provocam a venda de grandes volumes, uma vez que a mudança do comportamento do consumidor, em geral, não é imediata. Sendo assim, num primeiro momento, a quantidade demandada varia pouco $-\mathrm{Q}_{0} \rightarrow \mathrm{Q}_{1}$. Passado esse primeiro momento de sutil aumento de demanda, o segundo momento é caracterizado por um aumento notável no volume de vendas, até que se atinja o segundo ponto de inflexão da curva, em que se passa a operar com rendimentos decrescentes, sendo que o aumento no volume de vendas se torna cada vez mais difícil e com gastos proporcionalmente maiores. A proposta de Lambin considera tudo mais constante, ou seja, não há outras variações, como de preço, concorrência, ambientais etc.

Quanto aos demais determinantes da demanda anteriormente apontados sob a óptica econômica, Philip Kotler (1973), ao definir os estados de demanda, ressalta a importância dos gostos e preferências do consumidor, ou seja, do seu comportamento em relação à determinada necessidade (bem ou serviço). Segundo o autor, de acordo com o tipo de estado da demanda dos produtos ofertados, as decisões e os tipos de tarefas a serem desempenhadas por profissionais de marketing e, especificamente, de marketing de serviços são diferentes.

Nesse sentido, Kotler $(1973 ; 1993)$ definiu oito estados de demanda e pontuou as principais atividades de marketing para cada um deles, conforme se apresenta a seguir (KOTLER, KELLER, 2005): 
- Demanda não desejada (negative demand) $\rightarrow$ A primeira tradução do termo negative demand para o português foi feita de forma literal, passando-se a utilizar o conceito "demanda negativa”. No entanto, sabe-se que não existe uma demanda que seja negativa (não se pode demandar menos 20 televisores, por exemplo) e, assim, decidiu-se traduzir o termo original para "demanda não desejada". Esse estado de demanda é definido como aquele em que os consumidores têm sentimentos negativos em relação ao produto ou serviço a ser adquirido.

- Demanda inexistente (no demand) $\rightarrow$ Não há conhecimento sobre o produto ou os consumidores não estão interessados em comprá-los.

- Demanda latente (latent demand) $\rightarrow$ Não há produto disponível no mercado que satisfaça a necessidade dos consumidores.

- Demanda em declínio (faltering demand) $\rightarrow$ A compra do produto é menos freqüente e por isso está diminuindo.

- Demanda irregular (irregular demand) $\rightarrow$ Ocorre principalmente quando há sazonalidade.

- Demanda plena (full demand) $\rightarrow$ A compra do produto ocorre conforme esperado.

- Demanda excessiva (over full demand) $\rightarrow$ O volume de compras é maior que a disponibilidade para venda.

- Demanda nociva (unwholesome demand) $\rightarrow$ Originalmente, a tradução para unwholesome demand era demanda indesejada. Porém, é preciso compreender mais amplamente o conceito para capturar o significado desse tipo de demanda. Nesse caso, qualquer nível de demanda já é considerada excessiva, uma vez que os tipos de produtos relacionados a ela geram resultados nocivos aos consumidores e à sociedade em geral. Exemplos clássicos desse tipo de demanda são bebidas alcoólicas, cigarros e drogas.

Com essas interpretações de tipos de demanda, Kotler alerta para o fato de o marketing não trabalhar apenas com a expansão da demanda, situação em que a maior parte da teoria de marketing, se não toda ela, está embasada. Conforme afirmam Kotler e Levy (1971, p.75): “[...] na prática o excesso de demanda é um problema de marketing assim como a falta dela." Segundo esses autores, o marketing deve trabalhar para ajustar a demanda ao nível que o ofertante deseja ou pode atender.

A contribuição de Kotler nesse sentido é relevante, mas considera-se que não havia necessidade de se encontrar uma definição formal para cada um dos tipos de marketing de acordo com o estado de demanda, conforme apresenta o Quadro 10. O próprio Kotler, em seu 
livro mais popular, “Administração de Marketing”, deixou de empregar os termos que outrora havia sugerido. Ademais, referindo-se ao emprego do termo demarketing, afirma: "Nós utilizamos o termo demarketing para dramatizar semanticamente um fenômeno negligenciado, mas isso não seria necessário se todas as situações de marketing fossem reconhecidas" (KOTLER, LEVY, 1971). Talvez essa também tenha sido a intenção nas denominações dos demais sete tipos de marketing.

Quadro 10 - Tarefas básicas do marketing.

\begin{tabular}{|l|l|l|}
\hline \multicolumn{1}{|c|}{ ESTADO DE DEMANDA } & TAREFA DE MARKETING & \multicolumn{1}{c|}{ NOME FORMAL } \\
\hline Demanda não desejada & Corrigir Demanda & Marketing de Conversão \\
\hline Demanda Inexistente & Criar Demanda & Marketing de Estímulo \\
\hline Demanda Latente & Desenvolver Demanda & Marketing de Desenvolvimento \\
\hline Demanda em declínio & Revitalizar a Demanda & Remarketing \\
\hline Demanda Irregular & Sincronizar a Demanda & Sincromarketing \\
\hline Demanda Plena & Manter a Demanda & Marketing de Manutenção \\
\hline Demanda Excessiva & Reduzir a Demanda & Demarketing \\
\hline Demanda nociva & Destruir a Demanda & Marketing de Modificação \\
\hline
\end{tabular}

FONTE: Adaptado de KOTLER, 1973, p.43.

Para Kotler (1973), o estado da demanda deve ser levado em consideração no processo de análise, planejamento, implementação, organização e controle em marketing. Tal entendimento influencia a definição do composto de marketing. No caso de bens ou serviços que enfrentem o estado de demanda não desejada, foco de estudo desta dissertação, o desafio é transformar o estado de demanda não desejada em desejada, em situações em que não há problema de oferta, e possivelmente equipará-la ao nível ofertado. Entende-se, assim, que tais produtos que enfrentam um estado de demanda não desejada podem ser trabalhados.

O estado de demanda não desejada, embora pouco estudado por acadêmicos, está longe de ser uma situação atípica no mercado. A princípio, esse tipo de demanda possui um mercado-alvo que não gosta do produto, ou seja, tem sentimentos, crenças e atitudes que geram certa resistência à sua compra. Apesar da sua impopularidade por todo ou parte do mercado, esse tipo de produto é comprado por razões de saúde, negócio ou conveniência (SCHWARTZ et al., 1986). Os produtos comumente definidos como sendo de demanda não desejada são vacinações, cirurgias, consultas médicas, tratamentos dentários, seguros, serviços funerários e 
serviço militar. Alguns consumidores têm aversão a viagens de trem ou avião, por exemplo, e nesse caso tais produtos também podem ser considerados de demanda não desejada (KOTLER, 1973; SCHWARTZ et al., 1986).

No intuito de propiciar uma compreensão mais abrangente sobre o termo, vale retomar a definição mais amplamente conhecida de marketing:

Marketing é um processo social por meio do qual pessoas e grupos obtêm o que necessitam e desejam com a criação, oferta e da livre troca de produtos [sic] e serviços de valor com outros. (KOTLER, KELLER, 2005, p.4)

Sendo assim, merecem destaque os conceitos de necessidade e desejo. Kotler e Keller (2005) definem necessidades como “[...] requisitos humanos básicos”, ou seja, são requisitos que, em essência, estão relacionados com a sobrevivência do ser humano, tais como comida, água, roupas, abrigo ou ainda recreação, educação e diversão. A necessidade freqüentemente é utilizada como sinônimo de motivação, pois, de acordo com Hawkins et al. (2007, p.176), "[...] quando um consumidor sente um vazio entre o estado desejado e seu estado atual, uma necessidade é reconhecida e vivenciada como um estado impulsionador denominado motivação".

Há na teoria do comportamento do consumidor inúmeros estudos sobre a motivação, sendo que entre os principais, segundo Hawkins et al. (2007) e Blackwell et al. (2005), estão os trabalhos de McGuire e de Maslow sobre a hierarquia das necessidades, que, em um segundo momento, poderiam ser estudados para melhor compreensão do comportamento do consumidor na compra de serviços de demanda não desejada.

As necessidades se transformam em desejo quando são moldadas por fatores sociais, pois o consumidor já tem um direcionamento de sua necessidade a um tipo de produto específico para satisfazê-lo. Vale lembrar, por fim, que a demanda surge quando os desejos estão respaldados pela capacidade de compra do consumidor. Muitos consumidores podem desejar um produto, mas nem todos têm dinheiro para adquiri-lo.

Transformar a necessidade em desejo é uma tarefa às vezes fácil, às vezes difícil e às vezes as atividades envolvidas no marketing não conseguem fazer tal transformação, sendo que é sobre 
isso que trata o marketing para produtos de demanda não desejada, cuja missão é tratar de fazer o marketing de produtos que suprem necessidades, porém não são desejados pelo consumidor. A grande questão em relação aos produtos de demanda não desejada é justamente torná-los desejáveis para que se transformem em demanda. Assim, sob essa óptica, outros produtos poderiam ser entendidos e gerenciados como sendo de demanda não desejada, tais como exames médicos, cursos de idiomas, cursos universitários, blindagem de carros, contratação de serviços de segurança ou de advogados, viagens de avião, além dos demais citados anteriormente.

Cabe aqui também uma reflexão acerca de um artigo que Kotler e Levy (1971) publicaram sobre Demarketing, apresentando questões e alternativas para o caso de demanda excessiva, situação quase oposta ao de demanda não desejada. Nesse artigo, Kotler e Levy (1971) sugerem alguns passos para reduzir a demanda, valendo, portanto, a reflexão sobre empregálos de maneira oposta para produtos de demanda não desejada:

- Diminuir investimentos em comunicação, alterando o conteúdo da mensagem;

- Reduzir a promoção de vendas, investimento menos no ponto de venda e em catálogos, displays etc;

- Reduzir a equipe de vendas ou o tempo gasto com o produto em questão;

- Aumentar o preço ou dificultar condições comerciais;

- Aumentar os custos psicológicos do consumidor para desencorajar a demanda;

- Reduzir a qualidade ou conteúdo do produto;

- Diminuir a quantidade de pontos de distribuição.

Pouco se encontra sobre o conceito de demanda não desejada nos livros de marketing (BOONE, KURTZ, 2006; PERREAULT JR., McCARTHY, 2005). Muitos deles, porém, com base no reconhecido artigo de Melvin T. Copeland publicado na Harvard Business Review em 1923, propõem uma classificação dos produtos, do ponto de vista do consumidor, considerando os hábitos de consumo. De acordo com essa proposta, os produtos são classificados em quatro tipos: bens de conveniência, bens de compra comparada, bens de especialidade e bens não procurados, conforme se pode verificar a seguir (COPELAND, 1923; BOONE, KURTZ, 2006; PERREAULT JR., McCARTHY, 2005): 
- Bens de conveniência: são aqueles que o consumidor compra com freqüência e empenha um esforço mínimo para isso, como doces, cigarros, sabonetes etc.

- Bens de compra comparada: diferentemente dos bens de conveniência, para a compra desse tipo de bens os consumidores despendem tempo na comparação de preço, qualidade, cores, estilo, etc. Os bens de compra comparada podem ser subdivididos em homogêneos e heterogêneos. Os homogêneos são aqueles que os consumidores consideram semelhantes quanto à qualidade, e por isso procuram comprar o produto de menor preço. Pode-se imaginar um produto anti-rugas. Se o consumidor achar que todos irão causar o mesmo efeito, a procura será pelo menor preço. Já os heterogêneos são tipos de bens de compra comparada que o consumidor considera como sendo diferentes entre si. Exemplos de bens de compra comparada heterogêneos são móveis, viagens, roupas, entre outros.

- Bens de especialidade: são aqueles que oferecem características únicas. Tipicamente são produtos com preços elevados, que possuem uma marca forte e cujos consumidores não aceitam substitutos. São exemplos de bens de especialidade algumas marcas de carro, equipamentos eletrônicos, serviços jurídicos, financeiros e médicos.

- Bens não procurados: consumidores potenciais não querem, não reconhecem necessidade ou não sabem que podem comprar esse tipo de produto. Os exemplos clássicos desse tipo de produto são seguros de vida, seguros saúde, serviços funerários e enciclopédias.

Como se pode perceber, esta proposta está fortemente arraigada no marketing de bens, mas também é utilizada para a classificação de serviços. A qualificação de bens ou serviços, conforme descrito anteriormente, não é estática, podendo ser entendida de acordo com diferentes pontos de vista. Ademais, certos produtos recebem classificações diferentes conforme o país e a cultura em que estão inseridos. A proposta de classificação de produtos de Copeland foi criticada por alguns autores (HOLTON, 1958; MIRACLE, 1965), mas é a mais freqüentemente encontrada nos livros didáticos.

Enquanto Kotler (1973) classifica o estado de demanda de um determinado bem ou serviço, Copeland (1923) tipifica os produtos em si. Sendo assim, admitindo-se as relações de troca no sistema de marketing, ou seja, considerando a existência de dois atores principais, a entidade ofertante e a entidade recebedora, entende-se que para a entidade ofertante sua demanda é não desejada, e do ponto de vista da entidade recebedora, ou seja, do consumidor, o produto é do 
tipo não procurado. Como nesta dissertação pretende-se investigar o lado da empresa, preferiu-se adotar a denominação atribuída por Kotler.

Para finalizar o presente capítulo, cabe ressaltar que existem poucos estudos acadêmicos sobre a utilização do composto de marketing para o gerenciamento do marketing de serviços. Em se tratando especificamente de serviços de demanda não desejada, até agora não se encontraram estudos sobre o assunto. Nesse sentido, propõe-se a realização de uma pesquisa de campo para verificar como a teoria e a prática sobre o gerenciamento de variáveis de decisão no marketing de serviços refletem nos serviços de demanda não desejada do mercado brasileiro.

O estudo de campo inicia-se no capítulo 3 e segue no capítulo 4 com as descrições e resultados encontrados. 


\section{MÉTODO DA PESQUISA DE CAMPO}

\subsection{Proposição da pesquisa de campo}

No capítulo anterior foram apresentadas e analisadas as principais questões relacionadas ao gerenciamento das variáveis de decisão em serviços, bem como a definição e caracterização de serviços de demanda não desejada. Após a revisão da literatura, como forma de contribuir para a melhoria do conhecimento sobre o marketing de serviços, propõe-se a realização de uma pesquisa de campo a fim de verificar de que maneira os conceitos apresentados tomam forma nos serviços de demanda não desejada.

Para apresentar os elementos metodológicos da pesquisa de campo é preciso retomar o objetivo geral desta dissertação, que é:

\section{Estudar o gerenciamento das variáveis de decisão de marketing em serviços de demanda não desejada do ponto de vista conceitual e prático.}

Nessa perspectiva, esta seção pretende apontar o mercado que será abordado na pesquisa de campo e explicar os motivos de sua escolha.

Entre os mercados identificados por Kotler (1973) como sendo de demanda não desejada, optou-se por estudar o de seguros. Esse mercado gera mundialmente uma receita total de US\$ 3,4 trilhões. Um estudo recente da Escola Nacional de Seguros do Brasil (FUNENSEG, 2007) prevê que essa cifra crescerá 2,5\% ao ano nos próximos anos. De acordo com a Funenseg, o mercado de seguros tende a expandir, uma vez que economias em crescimento necessitam de mais serviços de seguros, posto que famílias e empresas tornam-se mais vulneráveis a riscos.

Nesse contexto, o Brasil desempenha um papel proeminente, já que nos últimos anos seu mercado de seguros passou por um rápido crescimento. O resultado de 2006 foi favorável para o mercado de seguros brasileiro. $\mathrm{O}$ valor dos prêmios de seguros atingiu quase $\mathrm{R} \$ 60$ bilhões, crescendo $16,7 \%$ em termos nominais e $14,8 \%$ em termos reais e continuando a trajetória de expansão desde 2004. A estabilidade econômica e a inflação baixa, especialmente na década de 1990, contribuíram para o crescimento do mercado. Mas esse 
crescimento também se apóia na desregulamentação, na maior abertura do mercado interno ao capital estrangeiro a partir de 1996, na adoção de padrões internacionais em 2003 e na abertura de resseguros ao capital estrangeiro. Assim, as mudanças na legislação brasileira foi extremamente importante para o crescimento do mercado de seguros no país (FUNENSEG, 2007).

O mercado de seguros é composto por uma gama diversa de seguros (há, por exemplo, seguros de automóveis, patrimoniais, de transportes, de riscos financeiros, habitacionais, de responsabilidades, entre outros). De forma abrangente e simplificada, os seguros podem ser divididos em: de vida e não vida. Em 2006, o segmento dos seguros de vida atingiu no Brasil faturamento de $\mathrm{R} \$ 24,7$ bilhões, com crescimento de 21,4\%. O segmento, aliás, mantém-se em crescimento desde 2000, sendo, portanto, bastante importante para o mercado. Nesta dissertação este foi o ramo escolhido como foco da análise.

Do ponto de vista acadêmico, a necessidade da realização da pesquisa de campo sobre o tema justifica-se pelos seguintes motivos:

- A maior parte dos livros e artigos acadêmicos relacionados ao gerenciamento de variáveis de decisão em serviços tem origem norte-americana e européia. Mesmo assim, há poucos autores que tratam do tema.

- Os trabalhos acadêmicos sobre marketing de serviços no Brasil são escassos. Em uma pesquisa realizada no Banco de Teses da Capes (CAPES, 2007) foram encontrados 2.066 trabalhos, entre dissertações e teses, sobre marketing, dos quais apenas 75 abordam o tema "marketing de serviços". Desses 75 estudos, 9 abordam questões variadas sobre o serviço prestado por Instituições de Ensino Superior. Outro tema recorrente é o do comportamento do consumidor de serviços; há 14 estudos sobre o assunto, envolvendo, nesse caso, questões relacionadas à qualidade do serviço prestado.

- Os trabalhos sobre gerenciamento das variáveis de decisão em marketing de serviços no Brasil, tema central desta dissertação, são escassos, e, de fato, abordados de maneira tangencial. Na mesma busca realizada no Banco de Teses da CAPES foram encontradas as dissertações de Carlos Augusto da Silva Loures, que, em 2003, estudou a questão de evidências físicas no marketing de serviços de hospitais, e de Kleper Lemos Hakme, que, por sua vez, analisou, também em 2003, o marketing de serviços no mercado B2B. Finalmente, Adriana Mazeto Doro, no mesmo ano, apresentou, no programa de pós-graduação da PUC de 
São Paulo, as técnicas de comunicação em marketing em agências de viagens. De fato, nessa pesquisa apenas foram encontrados estudos recentes e que abordam particularidades do gerenciamento das variáveis de decisão em marketing de serviços em mercados específicos.

- Durante investigação sobre o mercado de seguros no Brasil, encontrou-se o trabalho de Marília Mattos da Rosa, da Universidade Federal do Rio de Janeiro, publicado em 1998, sobre o marketing de seguradoras. No entanto, o trabalho buscou identificar as atividades de marketing realizadas por empresas de seguro no Brasil. Já o trabalho de Silvio Nececkaite Sant'anna, da PUC de São Paulo, publicado em 2001, também aborda o marketing em empresas de seguro, mas com foco nas tendências das atividades de marketing nesse tipo de empresa.

Sendo assim, pode-se afirmar que o estudo do gerenciamento do marketing de serviços é pertinente. Nesse sentido, espera-se que a investigação acerca do seu emprego em serviços de demanda não desejada possa contribuir para o avanço do conhecimento sobre o tema.

Nas próximas seções do presente capítulo descrevem-se o tipo e o modelo de pesquisa escolhido. Ademais, discutem-se a abordagem metodológica da pesquisa de campo, o projeto da pesquisa e os procedimentos de a coleta de dados.

\subsection{Abordagem do método da pesquisa de campo}

Existem três tipos básicos de pesquisa em ciências sociais - pesquisa conclusiva, pesquisa explicativa e pesquisa exploratória - que precisam ser conhecidos para prover maior segurança ao pesquisador antes de se aprofundar em um tipo específico de investigação. Para Churchill (1991), eles diferem fundamentalmente em termos de objetivos, formulações das questões de pesquisa, métodos de coleta e análise de evidências.

Para Malhotra (2002), a pesquisa conclusiva, que pode ser do tipo descritiva ou causal, é “[...] concebida para auxiliar o responsável pelas decisões a determinar, avaliar e selecionar o melhor curso de ação a ser tomado em determinada situação" (MALHOTRA, 2002). As pesquisas conclusivas descritivas, segundo Selltiz et al. (1959), são amplamente utilizadas em pesquisas sociais com o objetivo de descrever características da sociedade ou de um fenômeno. Tem o intuito, ainda, de levantar opiniões, atitudes e crenças da população ou, de 
acordo com Gil (2002), descobrir a existência ou não de associações entre as variáveis estudadas.

A pesquisa do tipo descritiva causal, o segundo tipo de pesquisa conclusiva, é utilizada quando o pesquisador procura resolver questões de causa e efeito entre duas variáveis. Para tal, o pesquisador deve estar seguro de que uma variável é precedente da outra. As hipóteses de pesquisa exigem prova de causalidade e, por isso o problema de pesquisa e as hipóteses de pesquisa são bastante específicas (AAKER, 1995). Geralmente nesse tipo de pesquisa, utilizase a experimentação para analisar as variáveis.

Um estudo experimental é "[...] um conjunto de processos experimentais especificando (1) as unidades de teste e os processos de amostragem, (2) as variáveis independentes, (3) as variáveis dependentes, e (4) como controlar as variáveis estranhas" (MALHOTRA, p. 211, 2002,). Já, segundo Aaker (1995, p.322), experimentos são “[...] estudos em que as condições são controladas assim que uma ou mais variáveis independentes podem ser manipuladas para testar a hipóteses sobre a variável dependente".

As pesquisas explicativas, como o próprio termo indica, buscam identificar os fatores que contribuem para que determinado fenômeno ocorra (GIL, 2002). Esse é, segundo o autor, o tipo de pesquisa que mais contribui para o avanço do conhecimento, posto que de fato dá razões para o acontecimento dos fenômenos em estudo. Entretanto, em pesquisas sociais, esse é um tipo de pesquisa que encontra muitas dificuldades, uma vez que o método mais comum envolvido em pesquisas explicativas é o experimental, o que nem sempre é possível no estudo dos fenômenos.

Já a pesquisa do tipo exploratória, segundo Malhotra (2002), “[...] tem como principal objetivo o fornecimento de critérios sobre situação-problema enfrentada pelo pesquisador e sua compreensão". Para Selltiz et al. (1959), o estudo exploratório busca familiarizar-se com o fenômeno para poder formular um problema mais preciso de pesquisa ou criar novas hipóteses, além de apontar em detalhes as características de uma circunstância, um grupo ou um indivíduo específico. Tanto Mattar (1996) quanto Gil (2002) argumentam que esse tipo de pesquisa provê ao pesquisador maior conhecimento sobre o tema ou problema de pesquisa em perspectiva. 
Em geral, os procedimentos metodológicos para pesquisas de cunho exploratório são qualitativos (SELLTIZ et al., 1959; MALHOTRA, 2002). No campo da Administração, a pesquisa qualitativa não é tradicional, já que só a partir da década de 1970 percebeu-se um crescente interesse por esse campo de estudo (GODOY, 1995)

Sidney Levy (2005), em artigo sobre a evolução da pesquisa qualitativa no estudo do comportamento do consumidor, aponta alguns tópicos importantes de reflexão sobre o emprego dessa modalidade de investigação. Ele lembra que a pesquisa qualitativa cresceu a despeito da resistência de pessoas que preferiam confiar em métodos quantitativos para a compreensão de fenômenos.

Segundo o autor, em uma conferência recente da American Marketing Association, os pesquisadores que desenvolvem pesquisas qualitativas foram comparados a artistas modernos que fazem trabalhos irreais e distorcidos porque não são competentes para desenhar. Para Levy (2005), no entanto, tais pesquisadores são como Picasso, que sabia sim desenhar. $\mathrm{O}$ fato é que não há medidas apropriadas para mensurar os resultados de uma pesquisa qualitativa, que se mantém dentro dos critérios que governam a pesquisa científica. Além disso, os pesquisadores que utilizam a pesquisa qualitativa não ignoram ou desqualificam a utilização de métodos quantitativos, já que também reconhecem o seu papel no âmbito das pesquisas.

Após reflexão sobre os tipos de abordagens de pesquisa, entende-se que este estudo é de natureza exploratória e qualitativa, uma vez que:

- Há a intenção de familiarização com o gerenciamento das variáveis de decisão no marketing de serviços de demanda não desejada, assunto pouco abordado, sobretudo considerando-se a realidade do mercado brasileiro, promovendo maior conhecimento sobre o tema;

- A pesquisadora não dispõe dos recursos necessários para realizar uma pesquisa de caráter conclusivo;

- Pretende-se estabelecer um comparativo entre a teoria do marketing de serviços e sua utilização na realidade mercadológica brasileira. 


\subsection{Escolha do método de estudo de caso para a pesquisa de campo}

O estudo de caso é um dos métodos existentes para a execução de uma pesquisa qualitativa. Para Yin (2001, p.32), “[...] um estudo de caso é uma investigação empírica que indaga um fenômeno contemporâneo dentro do seu contexto da vida real, especialmente quando os limites entre o fenômeno e o contexto não estão claramente definidos". Um estudo de caso, segundo Stake (1994), é, ao mesmo tempo, o processo de aprendizado sobre o caso e o produto do aprendizado.

Eisenhardt (1989) afirma que o método de estudo de caso pode ser utilizado para atingir diversos objetivos, como prover descrições, testar ou gerar teoria. Além disso, é um método que envolve a análise intensiva de um número relativamente pequeno de situações, podendo até reduzir-se a um (CAMPOMAR, 1991).

Selltiz et al. (1959) apontam que o estudo intensivo de determinados exemplos selecionados, ou seja, de casos, estimula a criação de insights e sugere a elaboração de hipóteses de pesquisa. Isso pode ser feito por meio do exame de registros existentes, de entrevistas não estruturadas ou ainda de observação participante. Segundo os autores, o processo de estudo de caso torna-se adequado quando o pesquisador: em primeiro lugar, tem uma atitude receptiva e atenta de busca, e não de teste da realidade, tendo como foco principalmente o objeto que está sendo pesquisado; em segundo lugar, esforça-se em obter informações suficientes para caracterizar e explicar não só as especificidades do caso que está sendo estudado, mas também o que há de comum com outros casos; e, em terceiro lugar, tem a capacidade de reunir diversos aspectos das informações coletadas em uma interpretação unificada.

Darke et al. (1998) argumentam que para a definição de um projeto de estudo de caso se faz necessário o estudo aprofundado da teoria, de forma que o emprego do estudo de caso seja embasado na teoria existente, levando à escolha apropriada da unidade de análise e do número de casos a serem investigados. O número de casos a serem analisados depende do foco do estudo. Os casos únicos, segundo Darke et al. (1998), resultam em casos mais ricos em detalhes e são mais profundos. Já os casos múltiplos possibilitam a comparação de realidades diferentes e a verificação da questão de pesquisa sob ópticas distintas. 
De acordo com Mattar (1996), cujo livro tem como foco a pesquisa de marketing, não existem regras para a escolha dos casos a serem pesquisados. No entanto, o autor sugere que:

- Os casos reflitam comportamentos extremados, como, por exemplo, o melhor caso de sucesso ou o pior caso;

- Os casos sejam reflexo de uma mudança, preferencialmente abrupta;

- Os casos possibilitem reconhecer facilmente que passaram por condições especiais e possam comparados a outro que não tenha sido exposto.

Vale ressaltar que o estudo de um caso possibilita, segundo Yin (2001), a descoberta de relações que não poderiam ser encontradas de outra forma. As situações em que essa estratégia de pesquisa é mais adequada são aquelas em que o pesquisador procura responder a questões do tipo "por quê?" e "como?". De acordo com Bonoma (1985), a utilização de estudos de caso pode proporcionar oportunidades para a comunidade de marketing, uma vez que possibilita o estudo de problemas de marketing inéditos, ou seja, que por algum motivo ainda não foram abordados. O estudo de caso, segundo esse autor, pode aproximar os estudiosos do marketing à realidade empresarial, sendo, portanto, fonte rica para o desenvolvimento da teoria de marketing.

As argumentações anteriormente apresentadas reforçam o intuito da utilização do estudo de caso como método de pesquisa a fim de se atingir o objetivo proposto nesta dissertação. A escolha do referido método apóia-se nas seguintes justificativas:

- A questão a ser respondida com a pesquisa de campo é do tipo “como?". Mais especificamente, pretende-se responder a seguinte pergunta: Como se dá o gerenciamento das variáveis de decisão em serviços de demanda não desejada?

- Busca-se a descoberta de como se dá tal gerenciamento inserido nos acontecimentos contemporâneos, pois se procura investigar as empresas no contexto da vida organizacional real e no mercado atual.

Entretanto, apesar da aderência do método ao problema de pesquisa, se faz necessário conhecer as críticas e limitações do estudo de caso, que serão apresentadas a seguir. 


\subsubsection{Críticas e limitações do método escolhido}

Como todo método de pesquisa, o estudo de caso também recebe críticas, que, em vez de impedir sua utilização, devem servir para oferecer uma visão clara sobre as suas limitações.

Na visão de Gil (2002), a limitação mais grave do estudo de caso refere-se à dificuldade de generalização dos resultados obtidos, posto que a unidade amostral escolhida pode apresentar características bastante peculiares. Por conta disso, para esse tipo de método, quando comparado a outros, o pesquisador precisa estar mais bem capacitado.

Yin (2001) corrobora o fato de o estudo de caso apresentar limitação quanto à generalização, mas enfatiza que esse método pode ser generalizável em proporções teóricas, ou seja, quando o pesquisador tem o objetivo de expandir e generalizar teorias.

Bonoma (1985) argumenta que a aplicação de um estudo de caso pode ser bastante demorada, custosa e ardorosa, podendo suscitar a produção de inúmeros documentos ilegíveis. No entanto, Yin (2001) defende que isso ocorria no passado. Segundo o autor, técnicas atuais de estruturação do estudo tendem a evitar textos longos e desnecessários. Ademais, as formas atuais de coleta de informações não são tão dispendiosas quanto as utilizadas em outros estudos qualitativos, como os etnográficos ou baseados exclusivamente em observações participantes.

O autor ressalta que nem sempre é fácil encontrar um caso que seja adequado ao problema de pesquisa determinado pelo pesquisador. Além disso, Bonoma (1985) acredita que, como a maior parte dos estudos em marketing são dedutivos, numéricos e baseados na lógica da causalidade, torna-se difícil justificar a utilização de um método qualitativo para o entendimento do problema de pesquisa.

Macpherson (2000) aponta que os estudos do tipo qualitativo e os estudos de caso produzem informações caracterizadas pela ambigüidade e subjetividade. Por esse motivo, de acordo com Yin (2001), certos pesquisadores relutam em utilizar e respeitar resultados de pesquisas encontrados por meio de estudos de caso. Todavia, o próprio Yin (2001) lembra que o problema de viés em metodologias de pesquisa pode ocorrer em qualquer estratégia, quer seja em experimentos, quer seja em pesquisas quantitativas que utilizem aplicação de questionários, embora reconheça que esse tipo de problema ocorre com mais freqüência em estudos de caso. 
Para Campomar (1991), esse é um método de pesquisa social empírica que pesquisadores devem ter coragem de utilizar, a despeito de suas críticas.

\subsection{Escolha do projeto do estudo de caso}

Um projeto de estudo de caso deve ser escolhido e definido de maneira a abordar de forma apropriada o problema de pesquisa em questão. De acordo com Yin (2001), há duas dimensões principais que devem ser consideradas: o número de casos a serem estudados; e a natureza do estudo.

Em relação à quantidade de casos a serem estudados, deve-se fazer uma distinção sobre a utilização de casos únicos e de casos múltiplos. Yin (2001) argumenta que a abordagem única é indicada para pesquisas de casos únicos, extremos ou revelatórios, situações em que o caso único é decisivo. Sobre isso, Yin afirma:

\footnotetext{
Para se confirmar, contestar ou estender a teoria, deve existir um caso único, que satisfaça todas as condições para se testar a teoria. $\mathrm{O}$ caso único pode, então ser utilizado para se determinar se as proposições de uma teoria são corretas ou se algum outro conjunto alternativo de explanações possa ser mais relevante. (YIN, 2001, p.62)
}

Os estudos de casos múltiplos, de acordo com Yin (2001), fazem parte da mesma estrutura metodológica dos estudos de casos únicos, porém o fundamento lógico para a condução de casos únicos nem sempre pode ser satisfeito por casos múltiplos. Isso significa que é necessário verificar a adequação de um e de outro aos objetivos propostos. Nos estudos de casos múltiplos cada um dos casos deve servir para um propósito específico, seguindo dois conceitos principais: a replicação literal ou a replicação teórica. Na lógica da replicação literal esperam-se encontrar resultados semelhantes; já na teórica esperam-se resultados contrastantes.

Em relação à natureza do estudo, Yin (2001) aponta duas alternativas: estudos de casos incorporados e estudos de casos holísticos. Nos estudos de casos incorporados se dá atenção a subunidades de análise, que podem ser processos, reuniões, funções ou locais prédeterminados. Ainda assim o projeto do estudo de caso é denominado de projeto de estudo de caso incorporado. Por outro lado, denominar-se-ia como estudo de caso holístico caso o 
pesquisador tivesse como foco central apenas a natureza global de um programa ou organização, ou seja, da unidade de análise, analisando-a de maneira holística. Vale salientar que os estudos de caso holísticos devem ser conduzidos quando não é possível identificar subunidades lógicas de análise e quando a própria teoria é construída de maneira holística.

A seguir, a Figura 10 resume os quatro tipos de estudo de caso que podem ser realizados pelo pesquisador.

Figura 10 - Tipos básicos de projetos para estudos de caso.

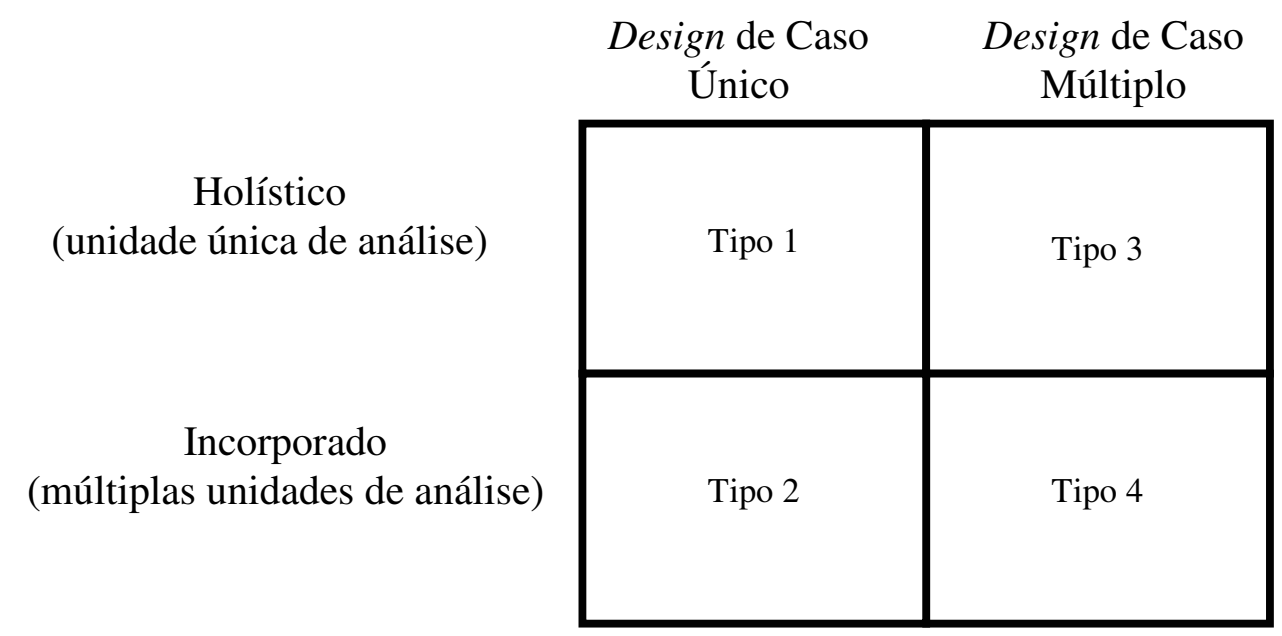

FONTE: YIN, 2001, p.61.

Stake (1994) propõe uma outra classificação para os estudos de caso. O autor identifica três diferentes tipos de estudo de caso que são adequados de acordo com os objetivos de pesquisa de cada pesquisador. O primeiro tipo de estudo de caso seria o intrínseco, que é adequado quando o pesquisador deseja ter um entendimento mais aprofundado sobre o caso em questão. Sendo assim, o caso não é escolhido porque pode representar outros casos, mas sim porque se tem interesse nas particularidades do caso. Nos estudos de caso intrínsecos não há o interesse de se obter a compreensão de problemas abrangentes ou até mesmo de se construir ou aprimorar a teoria.

O segundo tipo de estudo de caso definido por Stake (1994) é o instrumental, que tem por fim obter novas idéias sobre o tema de estudo ou ainda proporcionar o refinamento de determinada teoria. $\mathrm{O}$ estudo de caso em si não é o objeto de maior interesse; na verdade, 
serve como suporte que facilita o entendimento de algo maior, ou seja, do problema de pesquisa investigado. $\mathrm{O}$ caso no estudo de caso instrumental pode ou não ser visto como típico.

O terceiro e último tipo de estudo de caso definido pelo autor é o coletivo, que tem ainda menos interesse no caso que está sendo analisado. No estudo de caso coletivo os pesquisadores estudam um conjunto de casos que servem como base para o entendimento de determinado problema de pesquisa. Os casos podem ou não ser iguais, o que se destaca é que cada um dos casos tem sua importância própria. A escolha dos casos se dá porque o pesquisador acredita que seu estudo irá contribuir para o entendimento do problema de pesquisa.

Para este estudo foram selecionadas duas empresas atuantes no mercado de seguros, mais especificamente ofertantes de seguro de vida, e que apresentam atuação significativa no mercado. Buscaram-se empresas com departamento de marketing organizado e poder de decisão sobre as variáveis do composto de marketing, mesmo que com atuação seguindo parâmetros da matriz.

A fim de se alcançar o objetivo proposto neste trabalho, a estratégia de estudo utilizada foi de caso múltiplo e incorporado. Seguiu-se a linha instrumental e de replicação teórica, no intuito de encontrar insights sobre o tema em questão.

Sendo assim, os casos da Unimed Seguros e da MetLife serão apresentados mais adiante. A carta-convite que foi endereçada às organizações participantes está disponível no Apêndice A.

\subsubsection{Unidades de análises}

Um dos pontos importantes a serem definidos no processo de elaboração de um estudo de caso são as unidades de análise, ou seja, o caso em si que será estudado. De acordo com Perry (2001), a definição da unidade de análise relaciona-se com o problema de pesquisa em si. Uma unidade de análise pode ser um indivíduo, quando se pretende entender seu comportamento, suas características e suas reações em um determinado contexto. Também pode ser um evento ou uma entidade, sendo que nesse caso podem-se estudar quaisquer processos ou programas a eles relacionados (YIN, 2001). 
No estudo de caso proposto nesta dissertação, a unidade de análise é "o gerenciamento das variáveis de decisão em empresas ofertantes de serviços de demanda não desejada".

Ainda sobre a definição da unidade de análise do presente estudo, selecionaram-se duas organizações por conveniência e relevância no atual mercado de seguros. Foram escolhidas as empresas Unimed Seguros e MetLife para servirem como base para a unidade de análise mencionada anteriormente.

Conforme a lógica do estudo de caso incorporado, definem-se a partir da revisão da teoria as subunidades de análise, de maneira a garantir o foco na condução do estudo de caso e nas análises resultantes.

Sugere-se, assim, que as subunidades de análise sejam cada uma das variáveis de decisão do composto de marketing:

- Preço

- Distribuição

- Produto

- Comunicação

\subsubsection{Preparação para a coleta de dados no estudo de caso}

A preparação para a coleta de dados no estudo de caso é um dos passos mais importantes a serem dados. Segundo Darke et al.(1998), o tempo do pesquisador e o da fonte de informação devem ser utilizados de maneira justa, e por isso o planejamento deve ser rigoroso. A preparação se dá por meio do desenvolvimento do protocolo de pesquisa, que é, segundo Yin (2001), mais do que um instrumento de pesquisa, um documento que contém os procedimentos e as regras gerais que devem ser seguidos.

O protocolo de pesquisa é fundamental, pois confere à pesquisa confiabilidade e destina-se principalmente a orientar o pesquisador na condução da investigação. O protocolo atribui caráter cientifico à pesquisa, ou seja, caso seja realizada novamente, seguindo-se os mesmos passos de dado protocolo, pode-se chegar aos mesmos resultados encontrados inicialmente. 
A seguir será apresentado o protocolo de pesquisa, a fim de consolidar os principais aspectos do estudo de caso.

\subsubsection{Protocolo para o estudo de caso}

Yin (2001) propõe que o protocolo de pesquisa deva ser composto de quatro seções:

- Visão geral do projeto;

- Procedimentos de campo;

- Questões do roteiro de pesquisa; e

- Guia para o relatório do estudo de caso.

Cada uma das seções será desenvolvida a seguir, no intuito de sistematizar o projeto da pesquisa, criando regras de coleta que possibilitem o desenvolvimento de um estudo que contenha o rigor científico necessário.

\subsubsection{Visão Geral}

Na primeira parte da construção do protocolo de pesquisa é necessário descrever o contexto em que está inserido o projeto de pesquisa. $\mathrm{O}$ intuito dessa seção é dar a qualquer pessoa que deseja conhecer o projeto informações preliminares, ou seja, informações principalmente sobre os objetivos da pesquisa.

No estudo de caso proposto nesta dissertação, tem-se como objetivo principal identificar como as variáveis de decisão estão sendo utilizadas por empresas que comercializam serviços de demanda não desejada, conforme exposto ao longo da dissertação.

\subsubsection{Procedimentos de campo}

A coleta de dados para estudos de caso podem ser provenientes de seis tipos distintos de fontes de informação - documentação, registros em arquivos, entrevistas, observação direta, observação participante e artefatos físicos -, conforme apontado por Yin (2001). 
Documentação é o conjunto de cartas, memorandos, relatórios, recortes de revistas e jornais, entre outros tipos de publicações, que não devem ser entendidos como registros literais da realidade, mas como um meio de corroborar e valorizar as evidências provenientes de outras fontes de pesquisa. Outra fonte de informação são os registros em arquivos, isto é, aquilo que se encontra em arquivos eletrônicos no computador. Compreendem o registro de serviços prestados, tabelas e gráficos sobre o desempenho da organização ao longo do tempo, listas de nomes, registros (anotações) pessoais etc. Essa fonte de pesquisa deve ser utilizada em conjunto com outras fontes, e deve-se sempre levar em consideração as circunstâncias em que foram produzidos esses registros e observar a acurácia das informações.

As entrevistas, uma das mais importantes fontes de informação para estudos de casos, segundo Yin (2001), podem assumir caráter diverso, ocorrendo de forma mais espontânea ou mais estruturada. Em geral, o registro das informações coletadas nas entrevistas se faz por meio de gravações, que são posteriormente transcritas e analisadas pelo pesquisador.

A observação direta, outra fonte de coleta de evidências, se dá quando o pesquisador literalmente observa o fenômeno em questão, levantando informações comportamentais ou do ambiente em que se insere. Uma modalidade especial de observação direta é a observação participante, em que o pesquisador sai de sua postura passiva para atuar e participar do evento em estudo.

Na observação participante o pesquisador não é apenas um observador passivo. Neste tipo de observação o pesquisador pode assumir papéis de fato no fenômeno que está sendo estudado. Nessa situação o pesquisador necessita de cautela não se esquecer do seu papel na situação que está sendo investigada.

Por fim, os artefatos físicos consistem em quaisquer evidências físicas que possam ser coletadas ou observadas em uma visita a campo, tal como aparelhos altamente tecnológicos, obras de arte, ferramentas ou instrumentos. Os artefatos físicos assumem papel secundário na maior parte dos estudos de casos.

Para fins deste estudo buscou-se a utilização de múltiplas fontes de informações, com a pretensão de aproveitar os melhores aspectos de cada uma delas e também de evitar vieses devido a possíveis questões mal elaboradas ou respostas imprecisas e enviesadas. De qualquer 
forma, as entrevistas foram a fonte de pesquisa mais importante. Eisenhardt (1989) e Yin (2001) sugerem a utilização de diversas fontes de informação para proporcionar maior substancialidade e robustez dos construtos e hipóteses de pesquisa.

Dessa forma, foram coletados os dados de duas organizações do mercado de seguros de vida brasileiro. Tinha-se a intenção de se entrevistar pelo menos dois profissionais de cada organização, no entanto recebeu-se no primeiro estudo de caso a negativa de uma segunda entrevista. Os profissionais foram escolhidos segundo a conveniência (por meio de contatos pessoais da pesquisadora) e disponibilidade por parte da empresa. Optou-se também, nesse caso, por entrevistas semi-estruturadas, que foram gravadas e transcritas para posterior análise, permitindo assim uma maior fidelidade às informações coletadas.

A primeira entrevista do primeiro estudo de caso realizado serviu como piloto para o andamento do trabalho. Depois dela alguns ajustes foram realizados no roteiro de entrevista, disponível no Apêndice $\mathrm{C}$.

\subsubsection{Questões iniciais do estudo}

Este é o ponto central do protocolo de pesquisa, segundo Yin (2001). As questões apontadas nesta parte são as indagações que a pesquisadora faz a si própria, que, na verdade, servem de lembrete para o momento da entrevista.

Para este trabalho foram formuladas inicialmente as seguintes questões gerais:

- Quais fatores são levados em consideração para a tomada de decisão em relação ao preço na empresa ofertante de serviços de demanda não desejada estudada na pesquisa de campo?

- Quais fatores são levados em consideração para a tomada de decisão em relação à praça na empresa ofertante de serviços de demanda não desejada estudada na pesquisa de campo?

- Quais fatores são levados em consideração para a tomada de decisão em relação ao produto na empresa ofertante de serviços de demanda não desejada estudada na pesquisa de campo?

- Quais fatores são levados em consideração para a tomada de decisão em relação à promoção na empresa ofertante de serviços de demanda não desejada estudada na pesquisa de campo? 
A proposta inicial do protocolo de pesquisa com as questões específicas sobre cada uma das subunidades de estudo está disponível no Apêndice B. O roteiro final de pesquisa, construído após a entrevista piloto, é apresentado no Apêndice C.

\subsubsection{Análise e relatório do estudo}

Yin (2001) destaca a importância de se ter em mente a estratégia de análise que será realizada mediante os dados coletados. Esse autor propõe duas estratégias gerais. Uma delas é a análise baseada em proposições teóricas, que, de certa forma, está em linha com os objetivos da pesquisa e com o projeto como um todo. Esse tipo de estratégia é preferido, no entanto direciona o pesquisador a focar alguns tipos de informações e ignorar outras. A outra estratégia de análise é a descritiva, ou seja, quando o pesquisador desenvolve uma narração sobre o caso a partir de uma estrutura descritiva composta por capítulos que concentram questões centrais. É uma alternativa à falta de proposição teórica.

Para esta dissertação, optou-se pela estratégia descritiva, com a confecção de um relatório descritivo sobre o caso individualmente e, em seguida, a realização de uma análise comparativa entre a teoria e os achados do estudo de caso.

A seguir, no capítulo 4, serão apresentados os estudos de caso escolhidos para a presente dissertação: MetLife e Unimed Seguros. No capítulo cinco, teoria e prática serão confrontadas, buscando-se contribuir com novas idéias a respeito do tema desta pesquisa. Já no sexto e último capítulo serão apresentadas as conclusões e limitações desta dissertação, assim como sugestões para estudos futuros. 


\section{APRESENTAÇÃO INDIVIDUAL DOS CASOS}

Este capítulo apresenta os estudos de caso pesquisados nesta dissertação a fim de se cumprir o objetivo de estudar o gerenciamento das variáveis de decisão de marketing em serviços de demanda não desejada. Os estudos de caso selecionados foram o da MetLife e o da Unimed Seguros, empresas que por motivos diversos se destacam no setor de seguros no Brasil. Conforme o método de estudos de caso incorporados, o capítulo seguirá com a descrição do contexto em que as organizações estão inseridas, bem como com a descrição de cada uma das sub unidades de análise, leia-se: produto, preço, distribuição e comunicação. Cada caso se inicia com a exposição das fontes de informação consultadas para a elaboração do caso.

Cabe ressaltar que neste capítulo os casos estão sendo apresentados, com isenção de julgamento da autora, tendo-se tão somente a descrição das informações coletadas. Não há aqui o intuito de avaliar a eficácia ou eficiência do gerenciamento das variáveis de decisão em cada uma das organizações. Dessa forma, as diferenças ou semelhanças encontradas em cada um dos casos serão analisadas a fim de confrontar teoria e prática no capítulo seguinte.

\subsection{Análise do caso MetLife}

\subsubsection{Protocolo do estudo de caso MetLife}

\section{Visão Geral do Projeto de Estudo de Caso}

\section{$\underline{\text { A- Título }}$}

Variáveis de decisão de marketing em serviços de demanda não desejada.

\section{B-Objetivo do Estudo}

A dissertação tem por objetivo estudar o gerenciamento das variáveis de decisão de marketing em serviços de demanda não desejada.

\section{Procedimentos de Campo}

\section{A- Aspectos metodológicos}

Pesquisa de natureza exploratória com o uso do método de caso. 


\section{B- Organização}

Metropolitan Life Insurance (MetLife)

$\underline{\text { C- Unidade de análise }}$

Produto, Preço, Distribuição e Comunicação

D- Fontes de evidência

Entrevista em profundidade de acordo com roteiro de entrevista

$\underline{\text { E- Instrumento de coleta }}$

Roteiro de pesquisa

$\underline{\text { F- Executores da pesquisa }}$

Pesquisadora - Camila Gil

Orientador: Marcos Cortez Campomar

\section{Questões do Roteiro de Entrevista}

A- Dados da organização

1. Nome

2. Faturamento

3. Atuação

$\underline{\text { B- Dados do entrevistado }}$

1. Nome

2. Cargo

3. Atribuições na empresa

$\underline{\text { C- Questões de iniciais }}$

- Noção do conceito de demanda não desejada

- Como se dá o gerenciamento das variáveis de decisão

1 - Produto

- Identificar a essência do que está sendo ofertado pela organização a seus clientes 
- Definição de produto para o entrevistado e para a organização (núcleo do serviço, serviços suplementares)

- Identificar o conjunto de serviços auxiliares/suplementares

- Importância dos elementos físicos e sua definição

2 - Preço

- Estratégia de definição de preços adotada pela companhia

- Formas de pagamento

- Distinção de preços de acordo com os serviços suplementares

3 - Praça

- Identificar de que forma o serviço é vendido

- Existência de intermediários e seu papel

- Forma de monitoramento dos intermediários

- Estrutura (pessoas, tecnologia, equipamentos) envolvida no processo de distribuição

4 - Promoção

- Identificar as ferramentas de comunicação utilizadas para fazer a comunicação do seguro de vida

- Relevância de cada uma das ferramentas e seu papel

- Objetivo da comunicação

- Estrutura de campanhas publicitárias recentes

- Argumentos utilizados na comunicação

- Entender as atividades promocionais

- Apreender a função da marca para a organização

\section{Análise do estudo de caso}

Relatório descritivo além da comparação entre a fundamentação teórica e os elementos encontrados a partir do caso.

\subsubsection{Fontes de informações consultadas}




\section{Página na Internet}

A página da MetLife na Internet foi utilizada como fonte de pesquisa sobre a organização e sobre os serviços oferecidos. O acesso à página realizou-se no dia 4 de fevereiro de 2008 . Disponível em www.metlife.com.br.

\section{Documentos internos}

Documentos internos da organização, tais como folders, folhetos explicativos de produtos e material de treinamento serviram como fonte de consulta para extração de dados complementares.

\section{Entrevistas}

Entrevista com o Sr. Wilson Lima realizada no dia $1^{\circ}$ de fevereiro de 2008 em São Paulo na sede da organização.

O Sr. Wilson Lima, trabalha há cinco anos na MetLife, é coordenador da área de Treinamento e Desenvolvimento, tendo como foco o treinamento dos envolvidos com os canais de distribuição, ou seja, está diretamente envolvido com os corretores. É um profissional com mais de 10 anos de experiência no mercado de seguros do Brasil.

\subsubsection{Informações gerais sobre a MetLife}

A Metropolitan Life Insurance Company, MetLife, é uma empresa de origem norte americana fundada em 1863 em Nova York e desde o início teve como foco o seguro de vida e previdência privada. Hoje a empresa atua não só nos EUA e Brasil, mas na Argentina, Uruguai, Chile, México, Bélgica, Polônia, Inglaterra, Índia, Japão, Coréia do Sul, China, Taiwan, Hong Kong e Austrália. É a número um no mercado de seguros de vida individual e em grupo de solidez consolidada no mercado.

No Brasil, a MetLife está presente desde 1999 e se estabeleceu no mercado por meio de aquisições de seguradoras de menor porte e de parcerias estratégicas que permitiu que a empresa tivesse rápido crescimento no mercado brasileiro. Nesse processo, os principais destaques são:

- 1999: a MetLife concretizou parcerias com Libra Vida (antes Libra Clube) e Novo Vida (antes Novo Clube); 
- 2002: compra da Seguradora América do Sul (Seasul), cujo foco de atuação era a comunidade nipo brasileira;

- 2003: compra da carteira corporate da Seguradora Zurich;

- 2004: compra da Soma Seguradora;

- 2005: aquisição da MetLife Inc. da Travelers Life \& Annuity do Citigroup e todas as operações de seguros internacionais da Citigroup, incluindo a CitiInsurance no Brasil, numa transação grandiosa no valor de US\$ 11.8 bilhões.

Com isso, a então CitiInsurance do Brasil Vida e Previdência S.A passou a se chamar MetLife Vida e Previdência S.A.

No ano de 2006 a empresa teve um prejuízo na operação do Brasil na ordem de 66 milhões de reais por conta dos créditos consignados de aposentados. Em 2007 o prêmio ganho com seguros foi de 461 milhões, 6,2\% acima em relação ao ano anterior. Com isso, obteve em 2007 o primeiro lucro no Brasil na ordem de $\mathrm{R} \$ 10$ milhões de reais. A matriz norte americana passou também a acreditar no negócio brasileiro, fazendo um aporte de quase 40 milhões de reais. Hoje são 4,9 milhões de vida seguradas no Brasil das quais 1,7 milhões são individuais e 3,2 milhões no segmento corporativo entre grandes, médias e pequenas empresas.

A MetLife tem como missão: "Criar independência financeira para todos os nossos clientes" e a seguinte visão: "tornar-se líder reconhecido em todo o mundo na construção de relacionamento aliado a excelência em serviços financeiros, de forma a garantir que mais de 100 milhões de pessoas sejam nossos clientes até 2010".

\subsubsection{Produto da MetLife}

Os produtos classificados como de demanda não desejada, de acordo com a opinião do Sr. Wilson são muito difíceis de serem trabalhados, pois se faz necessário “... criar necessidade e vender serviços e produtos que as pessoas não querem comprar". O entrevistado traçou um paralelo com o mercado de televisores onde trabalhou anteriormente, onde se vende sonhos, enquanto na MetLife trabalha com um produto que está relacionado com momentos delicados da vida do consumidor.

$\mathrm{Na}$ visão do entrevistado os produtos de demanda não desejada são produtos não procurados pelos consumidores, sendo que o comportamento do consumidor relaciona-se com a falta de 
vontade de comprar ou só querer comprar mediante a uma fatalidade. Sr. Wilson conta que, de fato, a demanda é impulsionada por alguma fatalidade, tais como catástrofes naturais ou acidentes, como, por exemplo, o da queda do avião da Gol em 2006. Há parceiros de negócio no Rio de Janeiro, por exemplo, que contam que “... quando o morro desce minha demanda sobe", ou seja, a ameaça da violência urbana sensibiliza as pessoas a procurarem o seguro de vida. Em outras palavras, a demanda é sempre motivada por algo que não é bom, que não é positivo, de acordo com o entrevistado.

Os seguros de vida da MetLife são empresariais ou individuais. Os seguros empresariais são muito parecidos entre si, pois as garantias são em casos de morte acidental ou natural. Nos seguros empresariais a MetLife utiliza garantias acessórias para diferenciar o produto da concorrência.

- Assistência funeral: que auxilia os familiares no momento do funeral, que é acionado por meio de uma central 0800. Este é um momento bastante delicado e muitas vezes inesperado onde a situação financeira pode também ser desfavorável. A assistência cuida de tudo que for necessário nesse momento.

- Assistência cesta básica: que garante uma cesta básica para a família do segurado durante os 12 meses após a morte do segurado.

- Assistência viagem: que cobre problemas médicos, odontológicos ou ainda problemas com a bagagem em viagens para fora do país.

Cobertura de conveniência: desconto em escolas de inglês, estacionamentos.

Como o produto principal só gera benefício por conta de falecimento ou mesmo invalidez (no caso do seguro de acidentes pessoais) a MetLife busca gerar benefícios em vida para o segurado.

Para pessoas físicas o produto é essencialmente o mesmo, no entanto há outros diferenciais competitivos, tais como:

- Seguro de vida resgatável: parte do dinheiro pago pelo consumidor pelo seguro de vida é devolvido depois de 5 ou 10 anos, para ir ao encontro de consumidores que reclamam "... eu pago, pago, pago e não volta nada"

- Seguro de risco agravado: delineado para categorias que tem dificuldades para a compra de seguros de vida pelo alto risco envolvido em suas vidas. Caracteriza-se assim pessoas comuns 
ou profissionais que praticam com muita frequiência esportes radicais, pessoas que tem doença pré-existente ou ainda profissionais de risco tais como policiais, motoboys, eletricista de alta tensão, entre outros. Esse produto tem uma precificação diferenciada.

- Título de capitalização: alguns tipos de seguro de vida contém títulos de capitalização, que são um benefício ao segurado, sendo assim o segurado participa de sorteios semanais com prêmios que vão até 4 mil reais.

Um seguro diferenciado oferecido pela MetLife é o Seguro de Vida para estudantes, que segundo a empresa oferece proteção para quem estuda e tranqüilidade para quem ensina. Este produto indeniza morte por acidentes e cobre despesas médico hospitalares em caso de acidentes.

Além dessas coberturas, o MetLife AP Estudantes oferece assistências complementares para situações decorrentes de acidentes:

- Aulas domiciliares;

- Transporte para freqüência às aulas;

- Transporte para tratamento fisioterápico;

- Remoção inter-hospitalar;

- Monitoração médica;

- Indicação médica;

- Pacote de Assistência 24 horas;

- Central telefônica gratuita 24 horas por dia, 7 dias por semana.

Segundo o Sr. Wilson a MetLife vende ao consumidor garantia, tranqüilidade e em especial proteção que é a palavra mais utilizada na MetLife.

\subsubsection{Preço da MetLife}

Na MetLife há duas áreas que trabalham na definição de preços. A área de produtos, composto por uma área técnica, que trabalha junto com a área atuarial. Para exemplificar o que fazem o Sr. Wilson citou o caso dos seguros para os motoboys. A área técnica de produto junto com a área atuarial fazem previsões do tipo: quantos morrem por dia, quanto o consumidor vai pagar, quantos sinistros a empresa vai pagar, quantas vendas novas vão pagar os sinistros. "Basicamente pelo risco nasce a nossa precificação". 
Com essas informações definidas a área de marketing propriamente dita trabalha com a definição das estratégias de distribuição, comunicação etc. Isso tudo ocorre sempre com as aprovações da SUSEP: “A SUSEP está para nós assim como o Banco Central está para os bancos".

As pessoas físicas respondem um questionário de saúde que também entram no cálculo do preço do seguro.

A cobrança do seguro é feita mensalmente, trimestralmente, semestralmente ou anualmente. Há a possibilidade de haver um desconto para pagamentos anuais, porém mais de $90 \%$ dos pagamentos ocorrem mensalmente. Não há carências para o segurado, ou seja, o consumidor pode fazer o seguro em um mês e já receber o valor da indenização no mês seguinte.

Os serviços complementares são precificados a parte e alguns estão inclusos no valor do seguro pelo pequeno custo associado, por exemplo, o título de capitalização.

A faixa de preços varia muito, dependendo dos riscos incorridos em cada transação.

\subsubsection{Distribuição da MetLife}

A MetLife trabalha de duas formas para distribuir seu seguro de vida:

- Vendas às pessoas físicas: bancos, cartões de crédito e financeiras. São mais ou menos 15 parceiros, sendo que o Citibank é o principal parceiro.

- Vendas para o mercado corporativo: somente corretores de seguros. São aproximadamente 2 mil corretores em todo Brasil.

A empresa está estruturada em duas diretorias distintas para gerenciar esses dois tipos de canais de distribuição. Em cada uma das diretorias há gerentes de cuidam dos canais. A área de vendas para o mercado corporativo tem uma estrutura maior para atender os quase dois mil corretores em todo país.

A MetLife não faz vendas pela Internet. Nesse mercado não é comum utilizar esse canal de distribuição, segundo Sr. Wilson. 
Vale notar que a empresa não tem nenhum ponto de venda próprio, ou seja, uma loja da MetLife à qual possa se dirigir. O papel dos corretores, de acordo com Sr. Wilson é o de vendas, além de ser o elo principal entre a empresa e o consumidor.

\subsubsection{Comunicação da MetLife}

Fora do Brasil o investimento da MetLife é grande, pois há ação direta da empresa no varejo onde agentes de seguro oferecem os seguros aos consumidores potenciais.

O que sustenta a marca MetLife no Brasil e no Mundo é a Turma do Snoopy, que começou a ser divulgada por meio de tiras em jornais desde 1950 e que contam hoje com mais de 355 milhões de leitores por dia em 75 países. A parceria entre seu criador, Charles M. Schulz, e as empresas MetLife começou década de 80, quando a Seguradora e sua então agência de propaganda, a Young \& Rubicam (Y\&R), buscavam uma campanha publicitária inovadora.

O principal objetivo das empresas MetLife era a criar uma propaganda memorável que a diferenciasse de seus concorrentes e reforçasse os valores da marca, como confiabilidade, solidez financeira, flexibilidade e longevidade.

Inspirada na figura de Linus, um personagem que transmite confiança, com seu seguro e inseparável a turma do Snoopy fez sua estréia publicitária para a organização em 1985. Desde então foram feitos mais de 70 comerciais para televisão e inúmeros anúncios e folhetos, todos utilizando os personagens do Snoopy para transmitir mensagens sobre a força financeira da organização, a prontidão no pagamento das indenizações e outras características da companhia.

Utilizando a Turma do Snoopy desde o início de 1990 MetLife reposicionou sua mensagem publicitária, para fixar sua imagem como a de um valioso parceiro financeiro num mundo sempre em transição e ampliar a percepção da Seguradora como uma companhia que oferece grande variedade de opções financeiras.

No final de 2002, a organização anunciou a continuação do contrato de parceria com United Media para utilização da imagem do Snoopy e todos os demais personagens da Peanuts por mais 10 anos. As propagandas com a turma de Snoopy geram grande lembrança de marca e segundo a empresa tem fortalecido a reputação de solidez financeira e características como confiabilidade, know-how e produtos "amigáveis", o que tem ajudado bastante a aumentar o 
interesse na compra dos produtos da MetLife, principalmente entre as pessoas com menos de 50 anos.

No Brasil, a situação é diferente. A empresa quase não realiza investimentos em marketing visando fortalecer a marca e aproximá-la do consumidor.

No formato de trabalho hoje no Brasil "... quem tem que comprar a nossa imagem é o corretor e o RH da empresa, potencial cliente", ou seja, o corretor tem grande influência. Assim, os investimentos de marketing se direcionam aos canais de comunicação direcionados a esses públicos: revistas especializadas e em recursos humanos, revistas de corretores de seguros e outras mídias relacionadas ao mundo corporativo. A empresa também faz investimentos em eventos direcionados a esses públicos.

No varejo, a marca do parceiro da MetLife é mais importante para o consumidor do que a marca da MetLife. Os bancos, cartões de crédito ou financeiras oferecem o seguro sem citar o nome da MetLife. O consumidor só sabe quem é a empresa seguradora quando recebe os papéis do contrato em sua residência. Opta-se por fazer isso, pois o consumidor não entenderia o fato de, por exemplo, a Credicard oferecer um seguro da MetLife.

Ações diretas ao consumidor final são raras. O Sr. Wilson citou uma ação conjunta entre Citibank e MetLife nas agências do banco, onde haviam cartazetes e enfeites de mesa falando sobre o seguro de vida com estaque para a marca da seguradora.

O pilar da comunicação da empresa é proteção. A empresa investe mais no produto do que na marca.

Em relação aos investimentos em comunicação com corretores, a MetLife tem direcionado investimentos em campanhas de incentivo para seus corretores, principal canal de distribuição e divulgação de seus produtos. A campanha denomina "Campanha de Integração MetLife" incentiva a venda de produtos estratégicos para a Cia, tendo como foco especialmente os produtos de Seguro de Vida. O seguro de vida individual é o que mais vale dentro da mecânica de acumulo de pontos:

- Seguro de vida individual vale 25 pontos

- Seguro de vida para pequenas e médias empresas vale 15 pontos

- Seguro de vida empresarial vale 5 pontos 
No final de cada mês da Campanha a primeira parcela paga de cada um dos seguros vendidos é convertida em pontuação e esse pontos somados podem ser trocados por eletroeletrônicos, eletrodomésticos, itens de Cine\&Foto, Esportes e Lazer, Ferramentas, Jogos Eletrônicos e Viagens.

Como há corretores espalhados em todo o país, a MetLife elegeu a Internet como forma de se comunicar com os corretores, sendo que há um site exclusivo para tal campanha, o www.integracaometlife.com.br. Pelo site os participantes podem obter informações sobre a campanha, acompanhar o extrato de pontos e entrega dos produtos que foram resgatados.

\subsection{Análise do caso Unimed Seguros}

\subsubsection{Protocolo do estudo de caso Unimed Seguros}

\section{Visão Geral do Projeto de Estudo de Caso}

\section{$\underline{\text { A- Título }}$}

As variáveis de decisão de marketing em serviços de demanda não desejada.

\section{B-Objetivo do Estudo}

A dissertação tem por objetivo estudar o gerenciamento das variáveis de decisão de marketing em serviços de demanda não desejada.

\section{Procedimentos de Campo}

\section{A- Aspectos metodológicos}

Pesquisa de natureza exploratória com o uso do método de caso.

\section{B- Organização}

Unimed Seguros

C- Unidade de análise

Produto, Preço, Distribuição e Comunicação 


\section{D- Fontes de evidência}

Entrevista em profundidade de acordo com roteiro de entrevista

$\underline{\text { E- Instrumento de coleta }}$

Roteiro de pesquisa

$\underline{\text { F- Executores da pesquisa }}$

Pesquisadora - Camila Gil

Orientador: Marcos Cortez Campomar

\section{Questões do Roteiro de Entrevista}

A- Dados da organização

1. Nome

2. Faturamento

3. Atuação

$\underline{\text { B- Dados do entrevistado }}$

1. Nome

2. Cargo

3. Estrutura do departamento de marketing

4. Atribuições na empresa

C- Questões de iniciais

- Noção do conceito de demanda não desejada

- Como se dá o gerenciamento das variáveis de decisão

1 - Produto

- Identificar a essência do que está sendo ofertado pela organização a seus clientes

- Definição de produto para o entrevistado e para a organização (núcleo do serviço, serviços suplementares)

- Identificar o conjunto de serviços auxiliares/suplementares

- Importância dos elementos físicos e sua definição 
2 - Preço

- Estratégia de definição de preços adotada pela companhia

- Formas de pagamento

- Distinção de preços de acordo com os serviços suplementares

3 - Praça

- Identificar de que forma o serviço é vendido

- Existência de intermediários e seu papel

- Forma de monitoramento dos intermediários

- Estrutura (pessoas, tecnologia, equipamentos) envolvida no processo de distribuição

4 - Promoção

- Identificar as ferramentas de comunicação utilizadas para fazer a comunicação do seguro de vida

- Relevância de cada uma das ferramentas e seu papel

- Objetivo da comunicação

- Estrutura de campanhas publicitárias recentes

- Argumentos utilizados na comunicação

- Entender as atividades promocionais

- Apreender a função da marca para a organização

\subsubsection{Fontes de informações consultadas}

\section{Página na Internet}

A página da Unimed Seguros na Internet foi utilizada como fonte de pesquisa sobre a organização e sobre os serviços oferecidos. O acesso à página realizou-se no dia 4 de fevereiro de 2008. Disponível em www.unimedseguros.com.br.

\section{Documentos internos}

Documentos internos da organização, tais como folders, folhetos explicativos de produtos e material de treinamento para corretores serviram como fonte de consulta para extração de dados complementares. 


\section{Entrevistas}

Entrevista com o Sr. Henrique João Dias realizada no dia $1^{\circ}$ de fevereiro de 2008 em São Paulo na sede da organização.

O Sr. Henrique João Dias, formado em Administração com MBA em Marketing pela Fundação Instituto de Administração. Ocupa o cargo de Superintendente de Produtos e Marketing da Unimed Seguros. As áreas que estão sob seu comando são responsáveis pela gestão, criação e manutenção dos produtos da organização. Também tem como função cuidar da identidade de marca, do gerenciamento das campanhas de comunicação e do treinamento das equipes de venda no que produtos (corretores e escritórios regionais).

Realizou-se também outra entrevista a Sra. Rosângela Comminato no dia 11 de março de 2008 na sede da instituição. Rosângela trabalha na Unimed Seguros há três anos e atualmente é gerente de marketing se reportando ao Sr. Henrique. Como gerente a Sra. Rosângela cuida do relacionamento com o cliente, marca e eventos, sendo que a área que cuida da marca é a que é mais trabalhada pela empresa e por ela.

\subsubsection{Informações gerais sobre a Unimed Seguros}

A Unimed Seguradora é uma empresa do Complexo Unimed ou sistema Unimed composto pela Unimed Participações, Unimed Seguradora e Unimed Seguros Saúde. A Unimed Seguros é a marca da Unimed Seguradora S.A. surgiu da preocupação com questões previdenciárias dos médicos cooperados de todo o país. Iniciou suas operações em 1989 com o objetivo de atender às demandas do Sistema Unimed, formado por cerca de 400 cooperativas, 100 mil médicos cooperados e mais de 14 milhões de clientes em todo o Brasil.

Percebeu-se, no entanto, que o sistema era esgotável e que se tinha um mercado grande fora do sistema. Em fevereiro de 1990 obteve autorização para atuar no ramo Vida e planos de Previdência Privada Aberta. Com isso a Unimed Seguros obteve rápido crescimento apoiado no seu próprio mercado composto por cooperativas, médicos, funcionários, empresas e usuários de planos de saúde, potenciais consumidores de seguros.

Atualmente, a empresa conta com mais de 4,8 milhões de segurados e está entre as maiores empresas do setor de seguros. A Unimed Seguros é uma empresa de capital 100\% nacional, 
tem sua sede em São Paulo e escritórios regionais em 25 cidades. Oferece uma extensa linha de soluções de seguros nos ramos de Vida, Previdência, Saúde e também Assistências. De acordo com informações da Superintendência de Seguros Privados (SUSEP, www.susep.gov.br) a Unimed Seguros no ramo de Seguro de Vida encontra-se na $16^{\mathrm{a}}$ colocação do ranking de um mercado de aproximadamente 100 participantes. É uma empresa sólida e em crescimento: o crescimento de seu faturamento de 2006 versus o ano anterior foi de $26 \%$ segundo dados internos na própria Unimed.

Sua missão é "Oferecer produtos de qualidade em Seguros de Saúde, Vida e Previdência, atendendo as necessidades das Cooperativas e do mercado em geral". E sua visão "Ser reconhecida como uma Empresa do Sistema Cooperativo com excelência em Seguros de Pessoas".

\subsubsection{Produto da Unimed Seguros}

Para o Sr. Henrique os produtos de demanda não desejada carregados de uma nuvem negativa, pelos quais os consumidores apresentam certa repulsa em relação à aquisição de um produto “... ou seja, o cliente não procura ou não quer tocar no assunto". Porém, tal sentimento na sua visão se dá em parte pelo fato do consumidor não ter conhecimento sobre o produto em questão. "A demanda tem um lado sombrio, uma vestimenta feia. Essa é a interpretação que a gente faz aqui”, referindo-se ao entendimento que a Unimed Seguros tem sobre os produtos de demanda não desejada.

Já a Sra. Rosângela comenta sobre a especificidade dos serviços de demanda não desejada, fazendo uma comparação com sua experiência com bens de consumo, em especial produtos de higiene e beleza. Há dois pontos importantes apontados: a intangibilidade e a fator desejo no processo de compra. A questão da intangibilidade em serviços, segundo sua visão é um fator importante que deve ser trabalhado pelas empresas de serviços, posto que tal característica dá mais credibilidade e segurança aos clientes, em especial, quando se trata de seguros, cujo principal benefício procurado é justamente a segurança. De fato, não há consumidor que se levante pela manhã com o desejo de comprar um seguro de vida diferentemente do que ocorre com produtos de higiene e beleza. Rosângela conclui que seguro de vida “... é um produto difícil, é um produto emocional”. 
A experiência mostra que as pessoas que conhecem mais o assunto pensam não só no benefício que trará para ele próprio, mas para a família. Essa opinião também muda, quando os consumidores vivenciam de perto um caso de morte de um colega próximo que deixa mulher e filhos: “... é quando mais se vende seguro de vida, pois sensibiliza”, relata o Sr. Henrique.

A Unimed Seguros, caso tivesse capital suficiente, faria uma campanha nacional para sensibilizar potenciais consumidores a sair da inércia, gerando conhecimento sobre a realidade do seguro de vida e demais seguros que tenham esse perfil. No entanto, além de uma limitação de verba esse seria um movimento do mercado como um todo e não uma atividade exclusiva da empresa de acordo com Sr. Henrique. Hoje a divulgação ocorre muito mais no boca a boca e na comunicação direta entre corretores de seguro e potenciais consumidores.

O seguro de vida na Unimed se direciona tanto para o mercado empresarial quanto para pessoas físicas. No caso da venda para pessoa jurídica os prêmios pagos são pequenos, concentram-se no total de pessoas que serão asseguradas e o seguro é vendido apenas como um benefício para os funcionários. No caso de pessoa física, tem-se então a situação descrita anteriormente no que se refere aos sentimentos do consumidor e o esforço para reverter seu comportamento inerte.

$\mathrm{Na}$ concepção mais ampla do que seria o produto ofertado pela Unimed, o Sr. Henrique afirma que a empresa vende fundamentalmente garantia: “... estou garantindo que eu vou dar uma indenização pra família dele quando ele morrer”. Já na visão da Sra. Rosângela a Unimed também vende garantia. Em suas palavras a essência do negócio pode ser traduzida como: “... você fica tranqüilo que a gente está aqui. A gente cuida de você”.

O mercado de seguros é extremamente regulamentado e por isso a oferta de seguros pelos concorrentes não apresenta concepções diferenciadas. O produto é comoditizado, cobre morte por qualquer causa natural ou por acidente. Os produtos complementares não são, segundo o Sr. Henrique, fator de diferenciação nesse mercado.

Os produtos do portfólio de seguro de vida da Unimed Seguros são apresentados no Quadro 11 a seguir: 
Quadro 11 - Principais Produtos do ramo vida da Unimed Seguros.

\begin{tabular}{|c|c|}
\hline Produto & Principais Coberturas \\
\hline Unimed Vida em grupo e Serit & $\begin{array}{l}\text { - Morte } \\
\text { - Indenização Especial por morte acidental } \\
\text { - Indenização por invalidez permanente, total ou parcial por acidente } \\
\text { - Indenização por invalidez funcional permanente total por doença } \\
\text { - Adicional de invalidez por acidente majorada } \\
\text { - Renda por incapacidade temporária (Serit) }\end{array}$ \\
\hline Unimed Acidentes Pessoais & $\begin{array}{l}\text { - Morte acidental } \\
\text { - Indenização por invalidez permanente, total ou parcial por acidente } \\
\text { - Adicional de invalidez permanente por acidente majorada }\end{array}$ \\
\hline Unimed Mulher & $\begin{array}{l}\text { - Morte } \\
\text { - Indenização por invalidez permanente, total ou parcial por acidente } \\
\text { - Indenização especial por diagnóstico de câncer de mama, ovários ou } \\
\text { útero - antecipação de } 40 \% \text { da Garantia Básica }\end{array}$ \\
\hline
\end{tabular}

FONTE: elaborado pela autora com base em materiais de treinamento Unimed Seguros.

$\mathrm{Na}$ Unimed, o departamento de marketing trabalha com o conceito de estar com o cliente da vida até a morte. A empresa oferece uma gama de produtos que vão do nascimento até a morte que podem constituir um diferencial para a empresa. As mulheres, quando ficam grávidas são acompanhadas pela área de medicina preventiva da Unimed. Certificando-se do nascimento do bebê, a empresa manda um kit com diversos produtos, de maneira a emocionála. Um pouco depois, a Unimed oferece um produto de Previdência Privada que poderá ser utilizado para pagar os estudos do filho e, a idéia é que este cliente permaneça com a Unimed com o Seguro de Vida, Assistência Funeral entre outros. Tudo isso vem ao encontro do slogan utilizado pela empresa: Unimed faz mais pela vida.

Deve-se lembrar que a pessoa que comprou o produto não é aquela que será beneficiada por ele. Há a preocupação, no entanto, em vida de cuidar para que a cobrança seja feita de maneira adequada, que a Central de Atendimento e corretores sejam capazes de dar informações corretas sobre o seguro. Ainda, há o que o Sr. Henrique denominou de "Cobertura Acessória" adquirida ou não no momento da compra do seguro. A cobertura se 
refere à Assistência Funeral no momento da morte do segurado. Assim, nesse momento todo o tramite de documentação e procedimentos para o enterro são efetuados pela empresa.

No que se refere à tangibilização da venda, o cliente recebe um certificado, atestando que ele tem uma garantia. O nome das pessoas que serão beneficiadas são descritas nesse certificado.

Não há benefícios dados em vida para os clientes do Seguro de Vida Unimed a menos que seja um seguro de vida resgatável. É um seguro que se paga como um seguro de vida, mas é possível resgatá-lo tal qual uma previdência privada.

\subsubsection{Preço da Unimed Seguros}

Como o mercado de seguros é regulamentado, não permitindo modificações no produto ofertado, o preço não é um fator de diferenciação entre os diversos concorrentes do mercado.

De forma geral, as empresas do setor de seguros não podem cobrar o que querem de seus segurados porque o cálculo de preço segue uma tábua atuarial, determinada pela SUSEP, órgão regulamentador do setor. Há uma tábua para cada tipo de seguro, que é o centro do modelo matemático desenvolvido pela empresa. Há a possibilidade das empresas trabalharem com uma tábua própria, desde que consigam comprovar para SUSEP a realidade da tábua proposta, segundo informações do Sr. Henrique.

Sendo assim, a precificação do seguro de vida é feita por meio de uma amostragem matemática, que está condensada em uma tábua atuarial também conhecida como tábua de mortalidade ou tábua de vida (vide Anexo). As tábuas são criadas a partir de dados provenientes principalmente de censos populacionais. Ela apresenta a probabilidade de morte e sobrevida de um determinado número de indivíduos em uma certa idade.

Para cálculo do preço do seguro, desenvolveu-se um modelo matemático, bastante complexo, que prevê a probabilidade de uma pessoa morrer de acordo com sua faixa etária. A previsibilidade de morte, portanto, diz quanto a empresa vai desembolsar para indenizar. Soma-se a isso a média de indenização por morte e então é feito o cálculo de preço do seguro de vida a ser pago no grupo.

A base do modelo matemático é a idade do indivíduo. Algumas empresas já utilizam outras variáveis para trabalhar com um preço menor, como por exemplo, se o indivíduo é ou não 
fumante, se pratica esportes etc. Na Unimed há um questionário de avaliação de risco com variáveis binárias (sim ou não) com uma série de questões relativas à saúde e doenças na família. Em alguns casos a área médica pede exames adicionais, sendo que em alguns casos o pedido de seguro é negado pela empresa ou ainda aceito com ressalvas que são sinalizadas no contrato.

Como o preço é definido a partir da idade, a variação dos valores cobrados do seguro de vida é enorme, acompanhando a previsibilidade de morte de um cliente jovem de 20 anos e um mais idoso. O pagamento é mensal por boleto ou débito automático. Em geral para que a operação se pague é necessário que o cliente permaneça na companhia por 12 a 24 meses.

O corretor que oferece o produto ao consumidor trabalha com três tabelas de preços diferentes que impactam diretamente seus ganhos, ou seja, a comissão do corretor diminui à medida que o preço ofertado ao consumidor também diminui.

Vale lembrar que outras assistências podem ser agregadas ao produto principal, como por exemplo, a assistência funeral que são cobradas a parte.

\subsubsection{Distribuição da Unimed Seguros}

O seguro de vida da Unimed Seguros pode ser adquirido de duas maneiras: por meio dos corretores terceirizados, ou por meio do balcão de vendas, assim denominado pelo entrevistado. Os balcões de vendas ficam nas Unicreds que são cooperativas de crédito do próprio sistema Unimed, que também funcionam como banco. O seguro de vida é oferecido no momento em que o consumidor se dirige a uma loja Unicred para pagar suas contas, pegar empréstimos etc.

Tanto no caso dos corretores quando das vendas realizadas pelas Unicreds o contato que a Unimed Seguros tem com o consumidor final é limitado, pois o contato fica a cargo dos parceiros de negócio.

A Internet não é um canal de compras para os seguros de vida, mas funciona como um canal de consulta sobre o produto ofertado. A Central de Atendimento é receptiva e pode realizar vendas do seguro de vida. Em alguns casos muito específicos a Central atua ativamente, ligando para consumidores potenciais na tentativa de realizar vendas. 
Os intermediários recebem treinamento sobre os produtos e suas características e são cobrados por vendas. Seu ganho se restringe à comissão sobre as vendas efetuadas. Existem campanhas de incentivo para direcionar as vendas do corretor, já que ele é independente e trabalha com seguros de diversas empresas. As campanhas de incentivo a vendas anuais consistem em uma mecânica de acumulo de pontos que podem ser trocados por viagens ou mesmo dinheiro dependendo da campanha. As últimas campanhas têm oferecido premiações em dinheiro, pois parecem mais adequadas ao público de corretores, segundo informações do Sr. Henrique.

Nas Unicreds o conflito quanto à venda de outros seguros é menor pela identificação que há com a marca.

Nos intermediários também há conflito entre os diferentes produtos do portfólio, ainda que em menor proporção, ou seja, há conflito quanto àquilo que o intermediário irá oferecer a um potencial consumidor. Nesse caso, segundo o Sr. Henrique o corretor oferece o produto que for lhe dar a maior comissão. As campanhas de incentivos contemplam também essas questões.

Estima-se que a Unimed trabalhe com três mil corretores e mais de 200 Unicreds em todo o Brasil e para o Sr. Henrique o conflito se resolve da seguinte forma: "Menor preço para o cliente e maior ganho para ele, ele vai escolher sua companhia”.

Para os corretores são realizadas campanhas de incentivo a vendas, inclusive direcionando maneiras de operacionalizar a compra de um seguro, como, por exemplo, utilizar a internet para transmitir os dados. O maior prêmio do ano passado foi um carro de médio porte. A empresa está trabalhando em um projeto para incrementar a comunicação e o relacionamento com os corretores, uma espécie de CRM (Customer Relationship Management).

\subsubsection{Comunicação da Unimed Seguros}

A Unimed Seguros se vale do nome Unimed associado ao Plano de Saúde, no mercado há mais de 40 anos, sendo que se vale, portanto das associações de marca do consumidor em relação à sua experiência com o Plano de Saúde Unimed. Atualmente um dos objetivos da equipe de marketing é: transformar a marca Unimed em um objeto de desejo em seguros de pessoas, desvinculando, desse modo, a imagem da Seguradora da imagem do Plano de Saúde. 
A marca é um fator muito importante nesse mercado, segundo a Sra. Rosângela, reforçando a idéia com a seguinte afirmação: “... um consumidor não vai adquirir um seguro de uma seguradora que ela não conhece, principalmente de uma Seguradora”, enfatizando a importância da marca nesse mercado. A marca é assim um pilar importante e está atualmente sustentada, de acordo com o Sr. Henrique, em solidez, confiabilidade e bons serviços. Um trabalho de marca está sendo realizado a fim de definir os pilares da marca.

Ao ser questionado sobre a diferenciação da marca Unimed Seguros em relação aos concorrentes o Sr. Henrique admitiu: “... aí é um problema sério. Na verdade não é nem diferencial. Eu me escondo atrás de uma concepção de Plano de Saúde”. O estudo de marca também está contemplando essa situação. A companhia vive no dilema da marca, pois ao passo que a marca associada aos planos de saúde é carrega de elementos bons, ela também é uma interferência aos demais produtos da empresa e, portanto ao seguro de vida em questão.

O diferencial da marca Unimed em relação à concorrência é seu nome no que tange a credibilidade da instituição e não no que tange a produto.

Nesse esforço, a Unimed firmou uma parceria com a WWF Brasil visando fortalecer a marca Unimed, como se os valores que permeiam a marca WWF passassem a transbordar para a marca Unimed, que possui valores similares aos da WWF, porém não explícitos ou claros para os consumidores conforme aponta a Sra. Rosângela.

Vale lembrar que a WWF, criada em 1961, é uma rede composta por organizações e escritórios em diversos países que têm como característica a presença tanto local quanto global e o diálogo com todos os envolvidos na questão ambiental. Tem como missão conter a degradação do meio ambiente, harmonizando a vida do homem com a natureza por meio da: conservação da diversidade biológica mundial, garantia da sustentabilidade dos recursos naturais renováveis e promoção da redução da poluição e do desperdício. Os valores então que a Unimed compartilha com a WWF são:

- empresa ecologicamente correta: "a gente acredita que para fazer mais pela vida é preciso fazer mais pelo planeta";

- sustentabilidade;

- socialmente responsável. 
A empresa acredita nesses valores e de fato realiza práticas coerentes com o que é comunicado: utiliza garrafas para economizar a utilização de copos descartáveis; utiliza papel reciclado para impressão de materiais internos e folhetos de comunicação, por exemplo.

A Unimed não faz investimentos em mídia de massa, por limitações financeiras, valendo-se de ações regionais conforme interesse da empresa, trabalhando em parceria com as Unimeds locais. Os investimentos de marketing hoje estão direcionados aos produtos e não à marca. $\mathrm{O}$ boca a boca acaba sendo a ferramenta mais importante.

Os investimentos em eventos e patrocínios são os mais importantes dentre as ferramentas de comunicação. Os investimentos em eventos estão focados no próprio sistema Unimed e eventos para corretores. O patrocínio que também se destaca como ferramenta de comunicação está sempre relacionado com saúde. Atualmente a Unimed patrocina um evento de tênis associando assim a marca à saúde.

As campanhas de incentivo ou de vendas, no entanto, é a forma de comunicação mais comumente utilizada. Essas campanhas visam incentivar as vendas via corretores, principal canal de distribuição dos seguros Unimed. Atualmente as campanhas de comunicação em massa não estão sendo realizadas visto que a verba disponível é limitada. O Sr. Henrique acredita que as campanhas de incentivos a corretores são uma atividade promocional da empresa, pois avalia que os produtos de demanda não desejada devem ser vendidos e não comprados. A compra é estimulada pelo vendedor, pois não há consumidor que diga “... eu acordei hoje com uma vontade de comprar seguro de vida". O comportamento de compra se dá de forma diferente de acordo com seu relato. Ainda, deve-se ter cuidado no estímulo ao consumidor, pois pode se tornar negativo, pejorativo, prejudicando a marca.

Dentro do sistema Unimed, costuma-se fazer mídia impressa em revistas importantes para o sistema. O foco da comunicação nesse canal é de produtos seja ele previdência, vida, saúde dependendo da receptividade de determinada praça ao produto que se deseja comunicar.

A internet também é considerada uma forma de comunicação com os clientes, porém não são utilizadas comunicações em outros sites. Outra forma de comunicação via Internet ocorre por meio da intranet das empresas que tem sua massa de funcionários segurados. As comunicações tem como foco notícias sobre saúde ou dicas diversas que façam sentido com o 
negócio Unimed. É uma maneira de manter contato com seus segurados de uma forma simpática.

Utiliza-se mala direta impressa e eletrônica como uma ferramenta de comunicação que utiliza informações do banco de dados da própria empresa para identificar consumidores potenciais para determinado produto.

Há placas de comunicação da marca Unimed que ficam na Rodovia dos Imigrantes e outra na Bandeirantes. As demais placas foram retiradas devido a Lei da Cidade Limpa. "Essas placas funcionam bastante. É impressionante como a visibilidade é grande”, comenta a Sra. Rosângela.

O tema da comunicação utilizado pela Unimed são os elementos da água, terra e fogo. Para o seguro de vida o gato, “(...) o gato tem sete vidas” afirma a Sra. Rosângela. Assim:

- para os produtos de Vida utiliza-se elementos Terra;

- para os produtos de Previdência utiliza-se figuras que simbolizam o elemento Água, por exemplo, utiliza-se o golfinho que é conhecido como um animal esperto;

- já para as Assistências são utilizados elementos do Fogo, onde se utiliza animais em extinção.

A Unimed faz um trabalho ativo de relações públicas divulgando notícias sobre a empresa no jornal, rádio, televisão, porém o foco sempre é o fortalecimento da marca Unimed. É uma área diretamente ligada à presidência. 


\section{ANÁLISE COMPARATIVA DOS CASOS COM A FUNDAMENTAÇÃO TEÓRICA}

A análise comparativa dos estudos de caso com a fundamentação teórica foi realizada a fim de encontrar respostas às questões iniciais da pesquisa de campo, sendo uma forma de geração de insights de conhecimento sobre o gerenciamento das variáveis de decisão para serviços de demanda não desejada. A replicação teórica das análises foi garantida, uma vez que se utilizou organizações distintas entre si, condição garantida especialmente pela origem de cada uma delas.

A Unimed Seguros é uma empresa brasileira, criada para atender o mercado cooperativista, fundada há quase vinte anos, com mais de 4,8 milhões de clientes em todo Brasil. Já a MetLife é uma empresa privada, de origem norte americana fundada há mais de cento e quarenta anos e com início das operações no Brasil há menos de 10 anos. Atualmente, segurando algo em torno de 4,9 milhões de vidas. O Quadro 12 a seguir resume as características que garantem a replicação teórica dos estudos de caso.

Quadro 12 - Resumo das características diferenciadoras das organizações estudadas

\begin{tabular}{|l|l|l|}
\hline Características & MetLife & Unimed Seguros \\
\hline Tipo & Privada & $\begin{array}{l}\text { Privada, porém raízes } \\
\text { cooperativas }\end{array}$ \\
\hline Origem & Norte Americana & Brasileira \\
\hline Fundação & $\begin{array}{l}1863, \text { no Brasil desde } \\
1999\end{array}$ & 1989 \\
\hline $\begin{array}{l}\text { Quantidade de vidas } \\
\text { seguradas }\end{array}$ & 4,9 milhões & 4,8 milhões \\
\hline
\end{tabular}

FONTE: elaborado pela autora.

A análise que se segue foi agrupada por sub unidade de análise dos estudos de casos onde se destacam pontos convergentes e divergentes de ambas as organizações e das organizações com a fundamentação teórica apresentada nesta dissertação.

\subsubsection{Análise da variável Produto}

Vale destacar em primeiro lugar em relação ao $\mathrm{P}$ de produto, a característica principal do tipo de serviço estudado nesta dissertação: os serviços de demanda não desejada. Para Kotler (1973) os produtos de demanda não desejada são aqueles que os consumidores apresentam 
sentimentos negativos em relação a ele e tendo certa resistência à compra. Tanto na MetLife quanto na Unimed Seguros essa foi uma característica ressaltada pelos entrevistados. $\mathrm{Na}$ Unimed Seguros o entendimento é que os seguros de vida estão envolvidos por uma "vestimenta feia" e por muitas emoções. Já na MetLife o entrevistado afirma que a empresa trabalha com produtos que as pessoas não querem comprar, sendo necessário, portanto, trabalhar o estado da demanda (KOTLER, 1973), que muda no caso específico de catástrofes naturais ou como reação ao recrudescimento da violência urbana, fato encontrado em ambos os casos.

Para McLean (1994) os serviços podem assumir papéis diversos de acordo com o ponto de vista do consumidor. No caso Unimed identificou-se que o seguro de vida assume o papel de garantia e conforto, características também encontradas na MetLife. No caso o conforto, pode ser entendido como tranqüilidade. Além desses conceitos a MetLife também trabalha com o principalmente com o foco em proteção para seus clientes. O conceito de garantia, conforto ou tranqüilidade podem ser entendidos como sendo o serviço central procurado pelo cliente, ou seja, de acordo com Bessom e Jackson (1975), Lovelock e Wirtz (2006) o motivo pelo qual o consumidor compra o serviço.

Além do serviço central, identificou-se os serviços suplementares (BESSOM; JACKSON, 1975; LOVELOCK; WIRTZ, 2006) na oferta da MetLife, que busca dar em vida benefícios aos seus segurados, utilizando para tanto as garantias acessórias, como por exemplo, auxílio funeral, cesta básica, viagens e descontos em escola de inglês ou estacionamento, pagas adicionalmente ao valor do seguros, mas que são vistas como uma ampliação do produto principal, diferenciando o seguro daqueles oferecidos pela concorrência. Por outro lado, na Unimed Seguros os serviços suplementares não foram identificados, pelo menos como tal nos seguros de vida, apesar da empresa também contar com Coberturas Acessórias que podem ser contratadas no momento da compra. O que difere ambas as empresa é que na primeira o gerenciamento dos serviços suplementares é consciente, diferentemente do segundo caso.

No mercado de seguros, especificamente, há regulamentações que limitam a criação de formas inovadoras para o produto central, ainda assim há produtos formulados a públicos específicos, buscando uma forma de diferenciar-se no mercado. $\mathrm{Na}$ Unimed esses produtos se direcionam a mulheres e médicos, que apresentam, de acordo com a empresa, necessidades específicas. Já na MetLife, encontrou-se produtos direcionados a públicos que, em geral, são considerados de alto risco e por isso recusados na maior parte das demais seguradoras. São 
eles profissionais que trabalham em funções de alta periculosidade tal como eletricistas de alta tensão e motoboys, por exemplo. Apesar das regulamentações do setor, ambas as organizações apresentaram uma gama de serviços suplementares definidos por Lovelock e Wirtz (2006) como realçadores e facilitares, estando esse último tipo mais presente. Para os autores esses dois tipos de serviço ampliam a função do serviço central.

As empresas apresentaram serviços que facilitam a comunicação do consumidor com a empresa, o que ocorre por meio de sites na Internet e Centrais de Atendimento ao consumidor. O serviço de recebimento de pedidos, que são transmitidos pelos corretores está sendo evidenciado na Unimed Seguros, que tem buscado a agilidade da Internet para prestar um serviço mais eficiente ao consumidor final. A utilização do site pelos corretores para a transmissão de pedidos é direcionada inclusive por campanhas de incentivo.

Vale notar que a utilização do site para a transmissão de pedidos visa melhorar o processo de prestação de serviços, ou seja, a arquitetura de serviços de acordo com Lovelock e Wirtz (2006). Por outro lado, como o processo de contratação dos seguros é feito por intermédio de corretores, que não são funcionários da empresa, há pouca intervenção da empresa no que diz respeito à variabilidade da prestação de serviços, apenas diminuída quando da entrega da apólice de seguro ao segurado, que ocorrem em ambas as empresas pesquisadas e, no caso da Unimed, são encaminhados certificados de garantias àqueles que serão beneficiados em caso de morte.

Em relação aos serviços realçadores não foram encontrados serviços de consulta, hospitalidade e salvaguarda, sendo o grande destaque as exceções, que no caso de seguros são tratadas caso a caso por especialistas da área médica e de outros departamentos da empresa. Sendo assim, a Flor de Serviços (LOVELOCK; WIRTZ, 2006) está de certa forma despetalada ou pela falta de gerenciamento ou pela inexistência dos demais tipos de serviços.

Assim como a gerência de pessoas, a gerencia do ambiente físico não está presente nos negócios estudados, visto que a venda dos seguros é feita por parceiros, seja por bancos como Citibank para MetLife, por cooperativas de créditos, como as Unicreds para a Unimed ou ainda por corretores espalhados por todo o país em ambos os casos.

A análise segue com a sub unidade de preço. 


\subsubsection{Análise da variável Preço}

No que tange o gerenciamento da variável preço, o mercado de seguros é um caso a parte, dada a alta regulamentação do setor realizada pela SUSEP (Superintendência de Seguros Privados), que não permite a livre composição de preços pelas empresas atuantes no setor. Isso acontece porque a definição dos preços dos seguros de vida é feita via modelos matemáticos que tomam como base a tábua atuarial, definida pelo órgão regulamentador, e que deve ser utilizada por todas as empresas do setor, salvo casos em que a própria empresa consegue desenvolver e comprovar ao órgão a veracidade de sua própria tábua.

A tábua atuarial, ou tábua de mortalidade apresenta a probabilidade de morte e sobrevida de indivíduos de determinadas idades. Além de utilizar a tábua no modelo matemático, utiliza-se também informações de quanto o consumidor vai pagar, dados históricos da quantidade de sinistros pago pela empresa, quantas vendas novas pagam um único sinistro etc. Assim, denota-se que a definição da faixa de preço de um determinado seguro se dá fundamentalmente baseada em risco e, sendo assim, quanto maior o risco maior será o valor cobrado do consumidor. Suposição que deve ser estudada em outra ocasião.

Viu-se no tópico anterior que ambas as empresas deste estudo utilizam-se do artifício de serviços complementares para incrementar as ofertas ao consumidor. Todos os serviços sejam os Assistenciais (por exemplo, cesta básica e assistência funeral) ou ainda tipos de seguros de resgatáveis são cobrados adicionalmente ao valor do seguro de vida. Por isso, essa variável não é um fator de diferenciação no mercado e assim uma variável que de fato pouco ou nada influencia no processo de decisão de compra do consumidor.

Sendo assim, o preço nesse tipo de serviço não assume o papel de indicador de qualidade, diferentemente do que afirmam Reardon et al. (1996) e Zeithaml e Bitner (2003). Esses autores ainda afirmam que há, no setor de serviços, dificuldade de comparação entre os serviços concorrentes, dada a maior variação existente na prestação de serviços e maior flexibilidade na formatação das idéias. Porém, isso não ocorre no mercado estudado dada a alta regulamentação do setor, que inibe a variabilidade das ofertas tanto de produtos quanto de preços, facilitando a decisão de compra do consumidor.

Sendo assim, pode-se dizer que as ofertas de cada uma das empresas não tende a inelasticidade (HOFFMAN; BATESON, 2003) pelo menos não por esses motivos apontados 
pelos autores, mas fazendo uma inferência, pode ser que as ofertas tendam a inelasticidade devido à importância da marca ou ainda à falta de conhecimento do consumidor.

Do ponto de vista da empresa sobre o gerenciamento de preços, a estratégia de determinação de preços pode ocorrer de acordo com três estratégias segundo Lovelock e Wirtz (2006), Zeithaml e Bitner (2003), Hoffman e Bateson (2003), que inter-relacionam-se. A primeira estratégia é a de custos. A segunda é a de definição de preços pelos concorrentes. Já a terceira leva em consideração a entrega de valor ao consumidor. Zeithaml e Bitner (2003) destacam que na prática as empresas devem considerar cada uma das três estratégias para tomar a decisão final de precificação.

No caso MetLife e no caso Unimed Seguros a estratégia mais presente na definição de preços é a de custo, visto que o cálculo dos preços ao consumidor é feito via modelos matemáticos complexos que levam em consideração o custo em que a empresa incorrerá, levando-se em consideração a probabilidade de sinistro. $\mathrm{O}$ foco em custo também se evidencia pelo fato de ambas as empresas possuírem áreas específicas para o cálculo de preço e pelo fato de que a decisão sobre o patamar de preços não ser de responsabilidade exclusiva da área de marketing.

Porém, observa-se que por força da regulamentação do setor, os produtos tendem à indiferenciação. Segundo Hoffman e Bateson (2003), a estratégia de definição de preços pela concorrência é a estratégia mais adequada quando as empresas oferecem produtos indiferenciados. De fato, nesse caso a regulamentação do setor torna os produtos indiferenciados e ao mesmo tempo estabelece uma base comum para a definição dos patamares de preços a serem oferecidos ao consumidor. De certa forma, isso também contribui com a decisão do consumidor que tem a garantia da equivalência de oferta de ambas as empresas de serviços. No entanto, esta não foi uma estratégia citada pelas empresas.

Por fim, a terceira estratégia de determinação de preço, a que considera a entrega de valor ao cliente é a menos evidente nos casos estudados, até pela particularidade do setor. Ainda assim, encontrou-se sinais dessa estratégia na MetLife, quando se falou sobre um dos tipos de seguros de vidas oferecidos pela empresa aos motoboys, categoria de profissionais que tem uma atividade profissional de alto risco e que tem na maior parte dos casos pouco dinheiro para desembolsar mês a mês. Segundo a MetLife, considerou-se esse fator na determinação de preços do serviço. No arcabouço teórico isso poderia ser enquadrado em uma das abordagens 
sugeridas por Zeithaml e Bitner (2003) sobre o entendimento de valor para o cliente que é "valor é o preço baixo".

Ainda, pode-se falar sobre uma outra abordagem que é "valor é tudo que obtenho por tudo o que dou", presente na estratégia de inclusão de preços adicionais quando da inclusão de serviços complementares ao serviço central. Tal estratégia foi identificada em ambos os estudos de caso.

A seguir faz-se a análise comparativa da variável distribuição entre os casos MetLife, Unimed Seguros e a teoria estudada.

\subsubsection{Análise da variável Distribuição}

Oumlil e Rao (1993) sustentam que a distribuição em serviços pouco se desenvolveu ao longo dos anos posto que o setor era altamente regulamentando. Essa afirmação também é válida para o setor de seguros, cuja regulamentação nesse aspecto faz necessário que a venda do seguro ocorra por meio de corretores de seguro, diferentemente do que ocorre nos Estados Unidos, por exemplo, onde as empresas desse setor podem vender a varejo.

A distribuição dos seguros de vida na MetLife é feita por intermédio de parceiros de negócio como operadoras de cartão de crédito, bancos e financeiras, sendo que o principal parceiro é o banco Citibank. Além disso, contam com mais de dois mil corretores de seguro em todo o país. Na Unimed Seguros, encontrou-se a mesma estrutura de canais de distribuição, sendo que para eles a Unicred, banco do sistema Unimed, desempenha papel principal na distribuição dos seguros, assim como os três mil corretores em todo país. Em nenhum dos casos a distribuição é feita por canal direto ou Internet.

Assim, a distribuição é feita de acordo com a classificação proposta por Zeithaml e Bitner (2003) por canais indiretos, ou seja, os intermediários são o verdadeiro elo entre as empresas e os consumidores. Nesse caso, como a distribuição é realizada por agentes/corretores como descrito pelas autoras, as empresas podem diminuir os custos de distribuição, aproveitar a habilidade dos agentes já que são especialistas no mercado e ter ampla representação em todo país.

No entanto, observou-se em ambos os casos, um aspecto não mencionado na teoria estudada: a importância e o investimento que é feito em treinamento desses canais de distribuição. 
Tanto na MetLife quanto na Unimed encontrou-se áreas de treinamento exclusivas para os corretores. Essas áreas são responsáveis não só pelo treinamento, mas também pelo desenvolvimento de materiais explicativos sobre o seguro de vida e estão ligadas à área de marketing. Como o canal de distribuição pode ofertar os seguros de várias empresas, o treinamento é uma forma de defender a oferta da empresa diante de um cliente potencial.

Uma desvantagem descrita na teoria ainda por Zeithaml e Bitner (2003) é a dificuldade de se controlar o preço ofertado ao consumidor final, dada a autonomia dos corretores. Isso, contudo não foi apontado pela Unimed como um problema. Em primeiro lugar porque o próprio preço é bastante regulamentado; depois, porque os corretores recebem um tabela de descontos máximos e mínimos que podem aplicar sobre o valor dos seguros de vida, o que influencia não só o preço final ao consumidor, mas também o quanto o corretor ganhará como comissão na transação.

Em ambos os casos estudados o papel do intermediário foi descrito como limitado. O papel desempenhado por eles é apenas o de vendas, pois toda a parte de cobrança e prestação de serviços nos casos de dúvidas e sinistros é realizado pela empresa proprietária da marca. Uma forma encontrada para direcionar a atuação dos corretores de vendas é a campanha de incentivo. Na Unimed, as campanhas têm como objetivo direcionar a oferta de seguros e a forma como o trabalho é realizado: no caso, direcionar a transmissão de dados via Internet para agilizar o processo de atendimento ao consumidor. Na MetLife o caso é o mesmo: direcionar a venda de produtos estratégicos. Assim, os conflitos de interesse encontrados no mercado são pouco importantes em ambos os casos, contrariam as preocupações de Zeithaml e Bitner (2003).

Segue-se a análise comparativa com a última sub unidade de análise a Comunicação.

\subsubsection{Análise da variável Comunicação}

$\mathrm{Na}$ análise comparativa do caso MetLife, Unimed Seguros e fundamentação teórica, o primeiro ponto que merece ser comentado é o dos objetivos da comunicação de marketing realizados pelas empresas deste estudo. Na MetLife, o entrevistado admitiu que os investimentos em comunicação de massa no Brasil são limitados, uma vez que as regulamentações brasileiras não permitem a atuação direta da Seguradora no varejo, diferentemente do que ocorre nos Estados Unidos. Além dessa limitação, a subsidiária 
brasileira tem recursos limitados o que dificulta o planejamento e execução de ações em mídia de massa e, sendo assim, o objetivo da empresa não é o de aproximar a marca do consumidor, ou mesmo lembrar o cliente sobre a empresa, conforme sugere Lovelock e Wright (2002) quando abordam o tema objetivo da comunicação.

Na Unimed Seguros, o caso não é diferente. A empresa também tem recursos limitados, o que segundo os entrevistados os impedem de fazer uma comunicação massiva. Para eles o ideal seria realizar comunicações que desenvolvessem o mercado de seguros, porém isso não tem sido possível.

Ainda, na visão de Lovelock e Wright (2002) a demanda deveria ser estimulada pela propaganda e a promoção de vendas, assim como no mercado de bens, no entanto o que se verificou é que isso não ocorre na MetLife e na Unimed Seguros. Como dito anteriormente, a demanda é estimulada por catástrofes naturais ou acidentes que de alguma forma fazem com que os consumidores saiam da inércia. A promoção de vendas é outra ferramenta de comunicação não encontrada para estimular a demanda, visto que se está tratando de serviços de demanda não desejada pelos quais as pessoas apresentam certa repulsa ou sentimentos negativos em relação a ele.

Kotler e Bloom (1984) por sua vez, afirmam que em serviços, a habilidade do contato pessoal para a persuasão é mais importante que aquela feita via mídias de massa. De fato, essa é a característica que foi observada nas duas instituições pesquisadas no estudo. Tanto a MetLife quanto a Unimed Seguros empregam os maiores investimentos em comunicação em campanhas de incentivo aos corretores, responsáveis por persuadir o consumidor à realizar a compra do seguros de vida. Os investimentos de ambas as empresas estão não só em campanhas de incentivo a vendas, que de forma geral trabalham com mecânicas de acumulo de pontos para serem trocados por viagens, serviços ou bens, mas também nos investimentos de treinamento, fonte de argumentos para persuadir o consumidor.

No que diz respeito à utilização de ferramentas de comunicação, portanto, o destaque fica para os investimentos em comunicação pessoal. Na Unimed Seguros, a comunicação boca a boca foi destacada como sendo uma forma de comunicação bastante eficaz na venda de seguros de vida, visto que confere maior credibilidade ao produto e torna o consumidor mais receptivo para receber informações (HOFFMAN; BATESON, 2003; ZEITHAML; BITNER, 2003; GRÖNROOS, 2003). Ambas as empresas também fazem investimentos em 
propaganda, publicidade e patrocínio. A Unimed comunica tanto a marca quanto o produto, utilizando um ou outro dependendo da praça em que o material será veiculado. Já na MetLife o principal objetivo é comunicar o produto, visto que a empresa se vale da marca Unimed me âmbito internacional. A participação em eventos direcionados a corretores é foco de grande parte dos investimentos, já que os corretores são o principal elo entre empresa e consumidor.

Legg e Baker (1987) defendem que o maior desafio da comunicação em serviços é a de tangibilizar o intangível, sendo que isso pode ser alcançado por meio da utilização de objetos tangíveis, a utilização de linguagem concreta e a dramatização. Na MetLife esse aspectos são trabalhados, porém com descontração. De acordo com a empresa o personagem do Snoopy transmite a idéia de confiança. A linguagem utilizada é precisa, mesmo porque as regulamentações do setor impõem certos cuidados na comunicação. A dramatização é feita utilizando os personagens da turma do Snoopy o que permite comunicar um assunto delicado de forma sutil.

A Unimed Seguros também utiliza um elemento na comunicação para tornar mais agradável o assunto seguro de vida. Nesse caso, a empresa utiliza animais, tais como girafas, macacos, golfinhos sempre relacionando o significado do animal com o serviço ofertado. Esse artifício torna o assunto seguro também mais agradável, ou pelo menos o consumidor mais receptivo às informações. O animal escolhido para as comunicações de seguros de vida é o gato, popularmente conhecido por ter sete vidas.

Um assunto ainda não abordado nesta seção é o da imagem de marca, que de acordo com Las Casas (2000) é de grande preocupação no setor de serviços, pois confere credibilidade ao serviço prestado, dando certa garantia ao cliente. Essa preocupação existe em ambas as empresas estudas, porém o investimento em marca é tão tímido quanto os demais investimentos em marketing. Na Unimed Seguros, a imagem de marca da Seguradora é fortalecida pelo trabalho de anos da Unimed Saúde, que é uma marca com credibilidade no mercado de planos de saúde. Pode-se entender como um trabalho de fortalecimento da marca o de relações públicas que visa divulgar informações de solidez e confiabilidade da empresa. Outro trabalho nesse sentido é a parceria da Unimed Seguros com a WWF, que segundo a empresa potencializa ou mesmo catalisa o processo de construção de marca: a WWF estende sua credibilidade no cuidado e preocupação com o meio ambiente para a Unimed, que também quer ser reconhecida por isso, sendo que neste caso o cuidado é "pela vida", slogan utilizado pela empresa. 
Já na MetLife, a imagem de marca é fortalecida pelo conhecimento de marca e pela tradição mundial da empresa. Além disso, a turma do Snoopy auxilia na lembrança de marca, já que os personagens são bastante conhecidos pelos consumidores potenciais. Porém, os investimentos no Brasil estão focados em ações direcionadas a públicos bastante específicos - recursos humanos das empresas e corretores - e tem como principal objetivo a divulgação dos produtos, ou seja, a marca é sustentada no Brasil pelo reconhecimento e fortalecimento da MetLife globalmente.

Por fim, vale comentar as funções assumidas pelas marcas de ambas as empresas de acordo com Kapferer (2003). Dentre as classificações propostas pelo autor, as marcas MetLife e Unimed Seguros assumem o papel de garantia, o que é influenciado pelo próprio setor de atuação. No entanto, devido as associações de marca que a Unimed Seguros tem realizado, no caso com a WWF, também pela associação com animais e a própria comunicação da empresa que aborda questões ambientais, traduzidas no próprio slogan da empresa "Unimed faz mais pela vida" a marca assume também a função ética de cuidado com o meio ambiente.

O Quadro 13 a seguir apresenta um resumo dos principais achados da análise comparativa dos casos com a teoria e, tem o intuito de consolidar a análise de cada uma das subunidades de análise dos estudos de caso com a teoria.

Quadro 13 - Resumo da análise comparativa

\begin{tabular}{|c|c|}
\hline Aspectos Teóricos & Achados-Chave dos Estudos de Caso \\
\hline $\begin{array}{l}\text { Produto } \\
\begin{aligned} \text { - } & \text { Serviços de demanda } \\
& \text { não desejada } \\
\text { - } & \text { Papel do serviço } \\
\text { - } & \text { Serviço Central } \\
\text { - } & \text { Serviços Suplementares } \\
\text { - } & \text { Serviços Facilitadores } \\
\text { - } & \text { Serviços Realçadores } \\
\text { - } & \text { Elementos Físicos e } \\
& \text { Pessoas }\end{aligned}\end{array}$ & $\begin{array}{l}\text { Caso MetLife } \\
\text { - Os seguros são classificados como produtos que as pessoas não querem } \\
\text { comprar. } \\
\text { - O seguro de vida assume o papel de garantia e conforto, no entanto o } \\
\text { conceito mais trabalhado é o da proteção, entendido como o serviço } \\
\text { central procurado pelos consumidores. } \\
\text { - A empresa se vale de serviços suplementares como assistências } \\
\text { acessórias, tais como, assistência funeral, cesta básica, viagem, descontos } \\
\text { em escolas de inglês e estacionamento a fim de diferenciar sua oferta da } \\
\text { concorrência. O conceito fundamental desses serviços é oferecer } \\
\text { benefícios em vida para o segurado. } \\
\text { Caso Unimed } \\
\text { - A compra do seguro é envolvida por muitas emoções. } \\
\text { - O seguro assume o papel de garantia, também entendido como o } \\
\text { serviço central procurado pelos consumidores quando adquirem o seguro. } \\
\text { - Apesar de também apresentar coberturas acessórias, a empresa não as } \\
\text { gerencia como serviços suplementares. }\end{array}$ \\
\hline
\end{tabular}




\begin{tabular}{|c|c|}
\hline & $\begin{array}{l}\text { Ambos os casos } \\
\text { - O estado da demanda muda quando ocorrem fenômenos naturais ou } \\
\text { sociais que ameaçam o cotidiano da população. } \\
\text { - Serviços facilitadores de comunicação com o consumidor pela Internet } \\
\text { e Central de Atendimento estão disponíveis, bem como transações } \\
\text { eletrônicas entre corretores e empresa. } \\
\text { - Dentre os serviços realçadores, destaque para os de exceção, visto que } \\
\text { cada caso tanto para contratação quanto para pagamento de sinistros é } \\
\text { tratado caso a caso. } \\
\text { - As empresas são gerenciam o ambiente físico e tem pouca influência no } \\
\text { P de pessoas, já que os seguros são vendidos por parceiros ou corretores } \\
\text { de seguros que não fazem parte do quadro da empresa. }\end{array}$ \\
\hline $\begin{aligned} \text { reço } & \\
\text { - } & \text { Preço como indicador } \\
& \text { de qualidade } \\
\text { - } & \text { Inelasticidade } \\
\text { - } & \text { Estratégia de } \\
& \text { determinação de preços }\end{aligned}$ & $\begin{array}{l}\text { Caso MetLife } \\
\text { - Em uma das modalidades de seguros de vida, aqueles direcionados aos } \\
\text { motoboys, por exemplo, a empresa utilizou a estratégia de precificação de } \\
\text { entrega de valor para o cliente, denominada "valor é preço baixo". } \\
\text { Ambos os casos } \\
\text { - O preço é extremamente regulamentado no mercado de seguros. As } \\
\text { empresas utilizam a Tábua Atuarial como centro do modelo matemático } \\
\text { que calcula os preços finais do seguro, que toma como base taxas de } \\
\text { mortalidade e idade do segurado. } \\
\text { - No mercado de seguros a oferta de produtos e a determinação de preços } \\
\text { apresentam menor variabilidade quando comparado a outros mercados. } \\
\text { Assim, entende-se que apresentam menor tendência a inelasticidade. } \\
\text { - A principal estratégia de precificação empregada é a baseada em custos, } \\
\text { visto que utilizam modelos matemáticos complexos que consideram o } \\
\text { risco de incorrer em custos levando em consideração a probabilidade de } \\
\text { sinistro. } \\
\text { - Apesar de na teoria se ter encontrado que para serviços indiferenciados } \\
\text { a melhor estratégia de definição de preços é aquela feita com base } \\
\text { concorrência, essa não foi citada nos casos estudados. }\end{array}$ \\
\hline $\begin{array}{l}\text { Distribuição } \\
\begin{array}{l}\text { - } \quad \text { Distribuição por canal } \\
\text { indireto } \\
\text { - Papel do intermediário } \\
\text { - Conflitos de interesse }\end{array}\end{array}$ & $\begin{array}{l}\text { Caso Unimed } \\
\text { - Direciona a atuação dos corretores de seguros por meio de campanhas } \\
\text { de incentivo que tem como foco produtos estratégicos da companhia ou } \\
\text { ainda direcionamento de condutas. } \\
\text { Ambos os casos } \\
\text { - Distribuição realizada por meio de canais indiretos, ou seja, parceiros } \\
\text { de negócio tanto na Unimed quanto na MetLife, onde as Unicreds e } \\
\text { banco Citibank, respectivamente são o elo entre empresa e consumidor. } \\
\text { Os corretores de seguros também são responsáveis pela distribuição. } \\
\text { - Os conflitos de interesse são minimizados nas empresas devido à } \\
\text { regulamentação de preços do setor e também devido ao papel somente de } \\
\text { vendas assumido pelos corretores, segundo relato das empresas } \\
\text { pesquisadas. }\end{array}$ \\
\hline
\end{tabular}




\begin{tabular}{|c|c|}
\hline $\begin{array}{l}\text { Comunicação } \\
\begin{array}{l}\text { Objetivos da } \\
\text { comunicação }\end{array} \\
\text { - Demanda estimulada } \\
\text { pela propaganda e } \\
\text { promoção de vendas } \\
\text { - Importância do contato } \\
\text { pessoal } \\
\text { - Tangibilizar o } \\
\text { - Intangível } \\
\text { - Imagem de marca } \\
\text { - Papel da marca }\end{array}$ & $\begin{array}{l}\text { Caso MetLife } \\
\text { - Principal objetivo é comunicar o serviço ofertado. } \\
\text { - Utiliza a turma do Snoopy em suas peças de comunicação. Emprega } \\
\text { linguagem precisa e dramatiza situações com a descontração e } \\
\text { confiabilidade da turma do Snoopy. } \\
\text { - Imagem de marca sustentada pelo conhecimento global da marca } \\
\text { MetLife e pela turma do Snoopy, que auxilia na lembrança de marca. } \\
\text { - Marca assume o papel de garantia. } \\
\text { Caso Unimed } \\
\text { - Faz comunicação para fortalecer a marca, mas comunica o serviço, } \\
\text { dependendo da praça de veiculação. } \\
\text { - Utiliza imagem de animais e seus significados na natureza para } \\
\text { comunicar-se com o consumidor e, assim, tornar o consumidor mais } \\
\text { receptivo ao tema. Para o seguro de vida o gato foi o animal escolhido por } \\
\text { ser popularmente conhecido pelas sete vidas. } \\
\text { - Utiliza-se da credibilidade da marca Unimed Saúde para fortalecer a } \\
\text { imagem da Unimed Seguradora. Realiza parceria com a WWF, tomando } \\
\text { emprestado sua imagem de preocupação com o meio ambiente. } \\
\text { - Marca assume não só o papel de garantia, mas também ético dada a } \\
\text { utilização de animais na sua comunicação e a parceria de com a WWF. } \\
\text { Ambos os casos }\end{array}$ \\
\hline
\end{tabular}

FONTE: elaborado pela autora com base nas entrevistas e em Bessom e Jackson (1975), Hoffman e Bateson (2003), Kapferer (2003), Kotler (1973), Kotler e Bloom (1984), Las Casas (2000), Legg e Baker (1987), McLean (1994), Lovelock e Wirtz (2006), Lovelock e Wright (2002), Reardon et al. (1996), Zeithaml e Bitner (2003). 


\section{CONCLUSÕES, LIMITAÇÕES E DESENVOLVIMENTOS FUTUROS}

Este último capítulo é constituído de três partes distintas. Na primeira parte são apresentadas as conclusões do estudo tendo como base a fundamentação teórica e os achados da pesquisa de campo. Em seguida são apresentadas as limitações e sugestões de desenvolvimentos futuros nesta área de conhecimento.

O intuito principal deste capitulo é consolidar o trabalho aqui realizado de forma a contribuir com o avanço do conhecimento no marketing de serviços e sobre os serviços de demanda não deseja, não deixando de contribuir com o desenvolvimento de estudos futuros.

O objetivo de estudo que é o de estudar os serviços de demanda não desejada do ponto de vista conceitual e prático foi alcançado. Realizou-se uma extensa revisão da literatura sobre dois conceitos centrais: o gerenciamento do marketing de serviços e os serviços de demanda não desejada. A elaboração e execução dos multicasos, caso MetLife e caso Unimed Seguros, seguindo a lógica da replicação teórica sugerida por Yin (2005), o que contribuiu para a geração de insights e atingimento do objetivo.

A seção a seguir apresenta as conclusões do estudo.

\subsubsection{Conclusões}

Considerando-se a importância de serviços na economia mundial e a crescente importância na economia brasileira, este trabalho foi desenvolvido com o objetivo de estudar o as variáveis de decisão de marketing em serviços de demanda não desejada do ponto de vista conceitual e prático.

Por conta da sua natureza exploratória, acredita-se ter alcançado os objetivos do estudo por meio da revisão da literatura e realização da pesquisa de campo em duas empresas do setor de seguros.

Espera-se que as conclusões e novas idéias proporcionadas por este trabalho possam contribuir com o desenvolvimento do marketing de serviços e com o melhor entendimento do gerenciamento das variáveis de decisão em serviços de demanda não desejada. 
Pode-se considerar duas contribuições principais como resultado desta dissertação. A primeira contribuição refere-se ao arcabouço teórico aqui consolidado sobre o gerenciamento do marketing de serviços, especialmente sobre as variáveis de decisão de marketing, bem como sobre os estados de demanda que podem servir como base para pesquisadores e profissionais de marketing. A segunda contribuição refere-se às informações coletadas e analisadas nos estudos de caso que podem ser avaliadas por outras empresas do mercado de seguros, servindo também como reflexão para demais serviços de demanda não desejada.

O gerenciamento das variáveis de decisão para serviços de demanda não desejada podem ser considerados semelhantes às descrições do gerenciamento para serviços de forma geral, com algumas particularidades. Nesta dissertação o foco de estudo foram as quatro variáveis: produto, preço, distribuição e comunicação.

A pesquisa de campo de cunho qualitativo e exploratório realizada em duas empresas de seguros propiciou a geração de novos insights para estudos futuros. A análise comparativa entre os casos e dos casos com a teoria, mostram semelhanças e diferenças entre eles.

Nos estudos de caso verificou-se que as empresas têm conhecimento sobre os serviços de demanda não desejada, definindo-os como serviços pelos quais as pessoas apresentam muitos sentimentos envolvidos e não tem o desejo de comprar. Apesar da teoria sugerir que os responsáveis pelas atividades de marketing trabalhem o estado da demanda, ambas as empresas não fazem investimentos nesse sentido, se aproveitando de eventos naturais e sociais como modificadores do estado da demanda. Tanto na Unimed quanto na MetLife o seguro assume o papel esperado pelo tipo de produto, ou seja, conforto, proteção, garantia, o que caracteriza o produto central. Diferentemente da Unimed, a MetLife gerencia garantias acessórias de maneira a diferenciar suas ofertas dos concorrentes. Os serviços do tipo facilitadores estão mais presentes em ambas as empresas, enquanto os realçadores foram encontrados de forma tímida no trato de exceções ou particularização de cada sinistro ou novo seguro. Ainda, as empresas pouco atuam no gerenciamento do ambiente físico e pessoas.

No que diz respeito à variável preço pouco se pôde abarcar como se dá seu gerenciamento para serviços de demanda não desejada, visto que o mercado de seguros, escolhido nesta dissertação, é extremamente regulamentado e, por isso há pouca flexibilidade no gerenciamento de decisões. Ainda assim, observou-se que contrário ao visto na teoria, as ofertas das empresas não tendem a inelasticidade como propõe a teoria, visto que há menor 
variabilidade nas ofertas e maior tendência à igualdade de preços. A definição de preços é centrada na proporção de riscos incorridos pela seguradora e não na definição de patamares de preços das empresas concorrentes como sugere a teoria para serviços que tendem à indiferenciação. Ofertas de preços diferenciados ocorrem associados a tipos de seguros também diferenciados, para públicos com características próprias, situação encontrada de forma mais evidente na MetLife.

Na variável distribuição encontrou-se as maiores similaridades entre as empresas pesquisadas. Ambas realizam a distribuição dos seguros de vida por meio de intermediários, seja por parceiros de grande porte ou por meio de corretores em todo o país. O papel dos parceiros de negócio está bem definido e centrado na venda dos seguros. Os conflitos de interesse, típicos em empresas de serviços que utilizam intermediários para ampliar a distribuição de serviços são minimizados por meio de treinamentos, mas principalmente de campanhas de incentivo que direcionam a atuação dos parceiros de negócio. Pode-se inferir que os conflitos de interesse são menos problemáticos neste setor, visto que há uma gama muito grande de agentes de distribuição.

Por fim, na variável comunicação, identificou-se que os objetivos de comunicação das empresas pesquisadas está alinhado com conceitos fundamentais da comunicação no marketing de serviços. Na MetLife o principal objetivo é o da comunicação de produtos, ou seja, tem o caráter informativo e educativo, enquanto na Unimed há uma mescla entre fortalecimento da marca e comunicação de produtos. Apesar dos apontamentos do arcabouço teórico sinalizarem as ferramentas de propaganda e promoção de vendas como impulsionadores da demanda, nos casos estudados variáveis incontroláveis foram apontadas como fundamentais para a modificação no estado da demanda. Quiçá as empresas poderiam investir em propaganda caso tivessem maior disponibilidade financeiras, possibilidade apontada no caso Unimed.

Ainda, observou-se que para as empresas pesquisadas o contato pessoal entre corretor e cliente potencial é fundamental para que a venda possa ocorrer, sendo o principal foco de investimentos. Vale enfim destacar que uma forma encontrada pelas empresas para tratar dos serviços de demanda não desejada foi a utilização de personagens que despertem nas pessoas sentimentos positivos, o que ocorre de maneira diversa, mas semelhante com a Turma do Snoopy e animais com significados sociais. As principais ferramentas de comunicação são o patrocínio, as relações públicas e campanhas de incentivos direcionadas aos corretores. Vale 
observar que a comunicação pessoal, boca a boca entre cliente e corretor foi apontada como de suma importância para a realização da venda.

\subsubsection{Limitações do estudo}

Uma das limitações encontradas neste estudo é de ordem bibliográfica. Na grande maioria das vezes os autores consultados são norte americanos ou europeus, reflexo da escassez de textos publicados no Brasil sobre o marketing de serviços. Além disso, raros foram os textos encontrados sobre os estados de demanda e mais especificamente sobre demanda não desejada.

Outra limitação deste trabalho se dá pela natureza metodológica utilizada para realizar a pesquisa de campo. Por se tratar de um estudo exploratório, os resultados encontrados não são passíveis de generalizações nem para o mercado estudado nem para outros mercados. As conclusões devem ser consideradas válidas apenas para os estudos de casos aqui apresentados.

Uma outra limitação decorrente do método de estudo diz respeito a vieses ocasionados pela pesquisadora. Apesar dos esforços realizados ao longo de todo o trabalho se faz necessário considerar possíveis limitações interpretativas das declarações dos entrevistados ou mesmo da análise de documentos disponibilizados pelas empresas.

Por fim, deve-se considerar a limitação dos profissionais entrevistados seja pela capacidade de interpretação dos fatos ou escopo de atuação nas empresas. Além disso, deve-se considerar a negativa de um maior aprofundamento nas informações fornecidas pela MetLife.

Na última seção a seguir, passa-se a apontar possibilidade de desenvolvimentos futuros dentro de tópico de estudo desta dissertação.

\subsubsection{Desenvolvimentos futuros}

A partir do estudo realizado nesta dissertação sobre as variáveis de decisão em serviços de demanda não desejada, estudo de caráter exploratório, foram descobertas idéias gerais sobre o assunto, que podem ser mais discutidas em estudos futuros por esta pesquisadora ou por outros pesquisadores também interessados no tema. 
A primeira possibilidade de estudo futuro é replicar a pesquisa de campo em um grupo mais abrangente de empresas de seguro, contemplando não somente os seguros de vidas, mas também demais tipos de seguro.

A segunda possibilidade seria a de um estudo que comparasse as variáveis de decisão em diferentes tipos de serviços de demanda não desejada, a fim de se investigar particularidades ou similaridades entre segmentos diversos.

Como terceira possibilidade, sugere-se um estudo quantitativo, de cunho conclusivo, sobre as variáveis de decisões.

Por fim, estudos futuros podem se aprofundar no comportamento do consumidor em relação aos produtos de demanda na desejada, definindo concomitantemente seu escopo ou suas características evidentes. 


\section{REFERÊNCIAS BIBLIOGRÁFICAS}

AAKER, David A.; KUMAR, V.; DAY, George S. Marketing Research. 5aed. New York: John Wiley Sons, 1995.

AMA. American Marketing Association. Disponível em: <http://www.marketingpower.com/ mg-dictionary.php?Searched=1\&SearchFor=services $>$. Acesso em: 15 de janeiro 2007.

Disponível em: <http://www.marketingpower.com/mg-dictionary.php?Search For=brand\&Searched=1>. Acesso em: 05 de março de 2008.

Disponível

em

$<$ http://www.marketingpower.com/_layouts/Dictionary.aspx?dLetter=M>. Acesso em $11 \mathrm{de}$ junho de 2008.

ARAÚJO, Claudia Affonso Silva; GORGULHO, Cristiane Fernandes. "A teoria de marketing de serviços: explorando os elementos do marketing mix de serviços”. Cadernos Discentes COPPEAD. Rio de Janeiro, n.15, p.32-59, 2002.

BANCO MUNDIAL. Disponível em: <www.worldbank.org>. Acesso em: 23 de janeiro de 2007.

BEAVEN, M. H.; SCOTTI, D. J. "Service-oriented thinking and its implications for the marketing mix”. The Journal of Service Marketing. Vol.4, n.4, p.5-19, Fall, 1990.

BENNETT, Anthony R. "The five Vs - a buyer's perspective of the marketing mix". Marketing Intelligence \& Planning. Bradford, vol.15, n.3, p.151, 1997.

BESSOM, Richard M.; JACKSON, Donald W. "Service retailing: a strategic approach". Journal of Retailing. Vol.51, n.2, p.75-85, Summer, 1975.

BLACKWELL, R. D.; ENGEL, J. F.; MINIARDI, P. W. Comportamento do Consumidor. São Paulo: Pioneira Thomson Learning, 2005. 
BLOIS, Keith. J. "The marketing of services: an approach". European Journal of Marketing. Vol.8, n.2, p.137-145, 1974.

BONOMA, Thomas V. "Case research in marketing: opportunities, problems, and a process". Journal of Marketing Research. Vol.22, n.2, p.199-208, May 1985.

BOONE, Louis E.; KURTZ, David L. Contemporary Marketing. 12ªed. USA: Thomson Learning, 2006.

BORDEN, Neil. "The concept of the marketing mix". Journal of Advertising Research. New York, vol.4, n.4, p.2-7, June 1964.

CAMPOMAR, Marcos C. “O Sistema de Marketing”. Revista Marketing. São Paulo, n.131, p.43-45, Setembro 1984.

- “Do uso de 'estudo de caso' em pesquisas para dissertações e teses em administração”. Revista de Administração. São Paulo, vol.26, n.3, p.95-97, jul/set. 1991.

CAPES. Banco de Dissertações e Teses. Marketing de serviços. Disponível em: $<$ http://servicos.capes.gov.br/capesdw/>. Acesso em: 08 de novembro de 2007.

CHURCHILL JR., G. A. Marketing Research: methodological foundations. Fort Worth: The Dryden Press, 1991.

COPELAND, Melvin T. "Relation of consumers buying habits to marketing methods". Harvard Business Review. Vol.1, n.3, p.282-289, April 1923.

CRESWELL, John W. Research Design: Qualitative and Quantitative Approaches. London: Sage Publications, 1994.

DARKE, Peta; SHANKS, Graeme; BROADBENT, Marianne. "Successfully completing case study research: combining rigour, relevance and pragmatism”. Info Systems Journal. Vol.8, n.4, p.273-289, October 1998.

EISENHARDT, Kathleen M. "Building Theories from Case Study Research”. Academy of Management Review. Vol.14, n.4, p.532-550, October 1989. 
FISK, Raymand P.; BROWN, Stephen W.; BITNER, Mary J. "Tracking the evolution of services”. Journal of Retailing. Vol.69, n.1, p.61-103, Spring, 1993.

FITZSIMMONS, James A.; FITZSIMMONS, Mona J. Administração de Serviços. Operações, estratégia e tecnologia da informação. $4^{\mathrm{a}}$ ed. Porto Alegre: Bookman, 2005.

FRYAR, Carolyn R. "What's Different About Services Marketing?” The Journal of Services Marketing. Vol.5, n.4, p.53, Fall, 1991.

FUNENSEG. Disponível em: <www.funaseg.com.br>. Acesso em: 10 de agosto de 2007.

FURRER, Olivier. "Service Marketing Self-Portraits: Introspections, Reflections and Glimpses from Experts". International Journal of Service Industry Management. Bradford, vol.14, n.1, p.148-151, 2003.

GIL, A. C. Como elaborar projetos de pesquisa. 4ªed. São Paulo: Atlas, 2002.

GILMORE, Audrey; CARSON, David. "Management competences for services marketing". The Journal of Services Marketing. Santa Bárbara, vol.10, n.3, p.39-57, June 1996.

GODOY, Arilda S. "A Pesquisa Qualitativa - Tipos fundamentais". Revista de Administração de Empresas. São Paulo, vol.35, n.3, p.20-29, Mai/Jun. 1995.

GOLDSMITH, R. "The personalized marketplace: beyond the 4Ps". Marketing Intelligence \& Planning. Bradford, vol.17, n.4, p.178, 1999.

GRÖNROOS, Christian. "A Service-Orientated Approach to Marketing of Services". European Journal of Marketing. Vol.12, n.8, p.588-601, 1978. “An Applied Service Marketing Theory”. European Journal of Marketing, vol. 16, n.7, p. 30,-42, 1982. . "From marketing mix to relationship marketing: towards a paradigm shift in marketing”. Asian-Australian Marketing Journal. Vol.2, n.1, p.9-29, 1994. 
. "The Marketing of Services". In: BLOIS, Keith. Oxford Textbook of Marketing. Oxford: Oxford University Press, 2000.

. Marketing: Gerenciamento e Serviços. Rio de Janeiro: Elsevier, 2003.

GROVE, Stephen J.; FISK; Raymond P.; JOHN, Joby. "The future of services marketing: Forecasts from ten services experts”. Journal of Services Marketing. Santa Barbara, vol.17, n.2/3, p.107-123, 2003.

GUMMESSON, Evert. Marketing de relacionamento total: gerenciamento de marketing, estratégias de relacionamento e abordagem de CRM para economias de rede. $2^{\mathrm{a}}$ ed. Porto Alegre: Bookman, 2005.

HAWKINS, Del I.; MOTHERSBAUGH, David L.; BEST, Roger J. Comportamento do Consumidor. Construindo a estratégia de marketing. Rio de Janeiro: Elsevier, 2007.

HOFFMAN, K. Douglas; BATESON, John E. G. Princípios de Marketing de Serviços. Conceitos, Estratégias e Casos. São Paulo: Pioneira Thomson Learning, 2003.

HOLTON, Richard H. "The distinction between convenience goods, shopping goods, and specialty goods”. The Journal of Marketing. Vol.23, n.1, p.53-56, July 1958.

HOUAISS. Dicionário da Língua Portuguesa. Serviço. Disponível em: <http://houaiss.uol. com.br/busca.jhtm?verbete=servi\%E7o>. Acesso em: 19 de janeiro de 2007.

HUNT, Shelby. Marketing theory: the philosophy of marketing science. Homewood: Irwin, 1983.

IBGE. Instituto Brasileiro de Geografia e Estatística. Disponível em: <www.ibge.gov.br>. Acesso em: 23 de janeiro de 2007.

IKEDA, Ana Akemi. "Estratégias de Promoção em Serviços: A Importância da Comunicação Boca a Boca". In: ENANPAD. Encontro Nacional dos cursos de Pós-graduação em Administração. Rio de Janeiro, 1997. 
JOHNS, Nick. What is this thing called service? European Journal of Marketing. Vol.33, n. 9/10, p. 958, 1999.

KAPFERER, Jean-Noël. As marcas, capital da empresa: Criar e desenvolver marcas fortes. $3^{\mathrm{a} e d .}$ Porto Alegre: Bookman, 2003.

KOTLER, Philip. "The major tasks of marketing management". Journal of Marketing. Vol.37, n.4, p.42-49, October 1973.

Administração de Marketing: análise, planejamento e controle. São Paulo: Atlas, 1986.

. "The major tasks of marketing management. Eight different types of demand situations dictate marketing strategy”. Marketing Management. Vol.2, n.3, p.52-56, 1993.

; BLOOM, Paul. N. Marketing Professional Services. New Jersey: Prentice Hall, 1984.

; KELLER, K. L. Administração de Marketing. A Bíblia do Marketing. 12ª ed. São Paulo: Prentice Hall, 2005.

; LEVY, Sidney J. "Demarketing, yes, demarketing”. Harvard Business Review. Vol.49, n.6, p.74-80, Nov/Dec. 1971.

; ZALTMAN, Gerald. Journal of Marketing. Vol.35, n.3, p.3-12, July 1971.

LAMBIN, Jean J. Información, decisión y eficacia comercial. Espanha: Ediciones Deusto, 1967.

LAS CASAS, A. L. Marketing de serviços. $2^{\mathrm{a} e d . ~ S a ̃ o ~ P a u l o: ~ A t l a s, ~} 2000$.

LEGG, Donna; BAKER, Julie. "Advertising strategies for services firms". 1987. In: LOVELOCK, Christopher. Services Marketing. $3^{\mathrm{a}}$ ed. New Jersey: Prentice Hall, 1996. 
LEVY, Sidney J. "The evolution of qualitative research in consumer behavior". Journal of Business Research. Vol.58, n.3, p.341-347, March 2005.

LOURES, Carlos Augusto. Um estudo sobre o uso da evidência física para gerar percepções de qualidade em serviços: casos de hospitais brasileiros. 2003. 232f. Dissertação (Mestrado) - Faculdade de Economia, Administração e Contabilidade, Universidade de São Paulo, São Paulo.

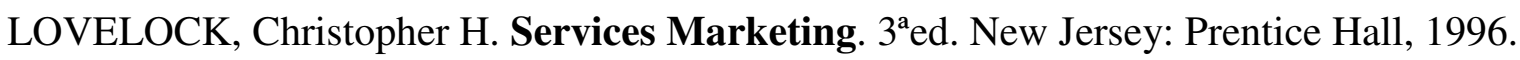
; WRIGHT, Lauren. Serviços. Marketing e Gestão. São Paulo: Saraiva, 2001. ; GUMMESSON, Evert. "Whither Services Marketing? In Search of a New Paradigm and Fresh Perspectives". Journal of Service Research. Vol.7, n.1, p.20-41, ago. 2004.

; WIRTZ, J. Marketing de Serviços. Pessoas, tecnologia e resultados. $5^{\text {a ed. São }}$ Paulo: Prentice Hall, 2006.

MacFADYEN, Lynn; STEAD, Martine; HASTINGS, Gerard. A Synopsis of Social Marketing. University of Strathclyde, Centre for Social Marketing, 1999. Disponível em: $<$ http://www.ism.stir.ac.uk/pdf_docs/social_marketing.pdf>. Acesso em: 14 de fevereiro de 2007.

MACPHERSON, Ian; BROOKER, Ross; AINSWORTH, Paul. "Case study in the contemporary world of research: using notions of purpose, place, process and product to develop some principles for practice”. Social Research Methodology. Vol.3, n.1, p.49-61, 2000.

MAGRATH, A. J. "When marketing services, 4 Ps are not enough". Business Horizons. Vol.29, n.3, p.45-50, 1986.

MALHOTRA, Naresh K. Pesquisa de Marketing. Uma Orientação Aplicada. $3^{\text {a } e d . ~ S a ̃ o ~}$ Paulo: Bookman, 2002. 
MANSFIELD, Edwin; YOHE, Gary. Microeconomia. Teoria e Aplicações. 11 $11^{\mathrm{a} e d}$. São Paulo: Editora Saraiva, 2006.

MATTAR, Fauzze N. Pesquisa de Marketing. Edição Compacta. São Paulo: Editora Atlas, 1996.

McCARTHY, E. Jerome. Marketing Básico: Uma Visão Gerencial. Rio de Janeiro: Zahar, 1976.

McLEAN, Fiona. "Services marketing: The case of museums". The Service Industries Journal. Vol.14, n.2, p.190-204, April 1994.

MIRACLE, Gordon E. "Product characteristics and marketing strategy". Journal of Marketing. Vol.29, n.1, p.18-24, Jan 1965.

MITTAL, Banwari; BAKER, Julie. "The services marketing system and customer psychology”. Psychology \& Marketing. Vol.15, n.8, p.727-733, Dec. 1998.

NICKELS, W. G.; WOOD, M. B. Marketing: relacionamento, qualidade, valor. Rio de Janeiro: LTC, 1999.

NORMANN, Richard; RAMIREZ, Rafael. "From value chain to value constellation: designing interactive strategy”. Harvard Business Review. Vol.71, n.4, p.65-77, 1993.

OUMLIL, A. Ben; RAO, C. P. "Services Marketing: Review and synthesis of critical distribution problems". The Journal of Marketing Management. Vol.3, n.2, p.6-16, Fall/Winter, 1993.

PARASURAMAN, A.; VARADARAJAN, P. "Future strategic emphasis in services versus goods businesses". The Journal of Services Marketing. Vol.2, n.4, p.57-66, 1988.

PERREAUlT JR., Willian D.; McCARTHY, Jerome E. Basic Marketing. A Global Managerial Approach. 15 ed. Los Angeles: McGraw-Hill, 2005. 
PERRY, Chad. "Case research in Marketing”. The Marketing Review. Vol.1, n.3, p.303323, Spring, 2001.

PINDYCK, Robert S.; RUBINFELD, Daniel L. Microeconomia. 4ªed. São Paulo: Makron Books, 1999.

PROCON. Disponível em: <http://www.procon.sp.gov.br>. Acesso em: 03 de julho de 2008.

RATHMELL, John M. "What is meant by service?" Journal of Marketing. Vol.30, n.4, p.32-36, October 1966.

REARDON, James; MILLER, Chip; HASTY, Ronald; WAGUESPACK JR., Blaise. "A comparison of alternative theories of services marketing". Journal of Marketing Theory \& Practice. Vol.4, n.4, p.61-72, Fall, 1996.

REGAN, William J. “The service revolution”. Journal of Marketing. Vol.27, n.3, p.57-62, July 1963.

SCHLESINGER, Leonard A.; HESKETT, James L. "The service-driven service company". Harvard Business Review. Vol.69, n.5, p.71-81, September 1991.

SCHULTZ, D.; BARNES, B. E. Campanhas estratégicas de comunicação de marca. Rio de Janeiro: Qualitymark, 2001.

SCHWARTZ, Martin L.; JOLSON, Marvin A.; LEE, Ronald H. "The marketing of funeral services. Past, present, and future”. Business Horizons. Vol.29, n.2, p.40-45, March-April 1986.

SELLTIZ, Claire; JAHODA, Marie; DEUTSCH, Morton; COOK, Stuart W. Research Methods in Social Relations. New York: Published for the Society for the Psychological study of Social Issues, 1959.

SHAPIRO, Benson P. "Rejuvenating the marketing mix". Harvard Business Review. Vol.63, n.5, p.28-34, Sep/Oct. 1985. 
SHIMP, T. A. Propaganda e Promoção. 5ªd. Porto Alegre: Bookman, 2002.

SHOSTACK, G. L. "Breaking free from product marketing”. Journal of Marketing. Vol.2, n.41, p.73-80, April 1977.

SIMONSEN, Mario Henrique. Teoria Microeconômica. Rio de Janeiro: Fundação Getúlio Vargas Serviços de Publicações, 1967.

SOLOMON, Michael R.; SURPRENANT, Carol; CZEPIEL, John A.; GUTMAN, Evelyn G. "A role theory perspective on dyadic interations: the service encounter". Journal of Marketing. Vol.49, n.1, p.99-111, Winter, 1985.

STAKE, Robert E. "Case Studies”. In: LINCOLN, Denzin. Handbook of Qualitative Research. California: Sage Publications, 1994.

SUSEP. Superintendência de Seguros Privados. Disponível em: <http://www.susep.gov.br/ menumercado/tabua.asp>. Acesso em: 19 de maio de 2008.

VAN DER ZWAN, Frank; BHAMRA, Tracy. "Services marketing: Taking up the sustainable development challenge”. The Journal of Services Marketing. Santa Bárbara, vol.17, n.4, p.341-357, 2003.

VARGO, Stephen L.; LUSCH, Robert F. "The Four Service Marketing Myths: Remnants of a Goods-Based, Manufacturing Model”. Journal of Service Research. Vol.6, n.4, p.324-335, May 2004.

VASCONCELlOS, Marco A. S. de; OLIVEIRA Roberto G. de. Manual de Microeconômica. 2a ed. São Paulo: Editora Atlas, 2000.

WATERSCHOOT, W.; VAN DEN BULTE, Christophe. "The 4P Classification of the Marketing Mix Revisited”. Journal of Marketing. Vol.56, n.4, p.83-94, October 1992.

WYCKHAM, R. G.; FITZROY, P. T.; MANDRY, G. D. "Marketing of Services. An evaluation of the theory". European Journal of Marketing. Vol.9, n.1, p.59-67, Spring, 1975. 
WWF BRASIL. Disponível em <http://www.wwf.org.br/wwf_brasil/wwf_mundo/index.cfm>. Acesso em: 25 de março de 2008.

XAVIER, Fernando Menezes. Formulação da estratégia de operações como fator de melhoria da competitividade no varejo. Tese (Doutorado em Engenharia de Produção), Universidade Federal de Santa Catarina, Florianópolis, 2005.

ZEITHAML, Valerie A.; PARASURAMAN, A.; BERRY, Leonard L. "Problems and Strategies in Services Marketing”. Journal of Marketing. Vol.49, n.2, p.33-46, Spring, 1985.

; BITNER, Mary J. Marketing de Serviços: a empresa com foco no cliente. $2^{\mathrm{a}} \mathrm{ed}$. Porto Alegre: Bookman, 2003.

YIN, Robert K. Estudo de Caso. Planejamento e Métodos. 2a ed. Porto Alegre: Bookman, 2001. 


\section{APÊNDICES}

APÊNDICE A - Carta convite da Pesquisa de Campo

APÊNDICE B - Protocolo Inicial da pesquisa

APÊNDICE C - Protocolo Final da pesquisa 


\section{APÊNDICE A}

\section{CARTA CONVITE DA PESQUISA DE CAMPO \\ UNIVERSIDADE DE SÃO PAULO \\ FACULDADE DE ECONOMIA, ADMINISTRAÇÃO E CONTABILIDADE DEPARTAMENTO DE ADMINISTRAÇÃO}

São Paulo, de 2008.

Prezado Sr.

(Nome da empresa)

Esta carta é um convite à sua organização para participar de um estudo exploratório como parte da dissertação de mestrado de Camila Gil, aluna da Faculdade de Economia, Administração e Contabilidade da Universidade de São Paulo.

O estudo aborda o gerenciamento das variáveis controláveis de marketing (do preço, da distribuição, do produto e da comunicação) de serviços de demanda por produtos não desejados. Esse tipo de serviço é assim denominado quando o consumidor apresenta sentimentos, crenças e atitudes que geram certa resistência à compra, que é o caso dos seguros de vida.

A participação da __ é muito importante para a conclusão deste estudo, posto que existem poucas organizações do setor de seguros tão bem organizadas e reconhecidas no Brasil. A pesquisa consiste na realização de até três entrevistas com pessoas indicadas pelo senhor e que sejam responsáveis pela tomada de decisão nas áreas de interesse do estudo. O tempo de duração estimado é de sessenta minutos para cada uma.

Após o término da dissertação, será enviada uma cópia do texto final para sua organização, contendo a fundamentação teórica do tema de estudo e os resultados empíricos encontrados. Seu nome e de sua organização serão divulgados no estudo.

Saudações acadêmicas,

Prof. Dr. Marcos Cortez Campomar

Professor Titular de Marketing 


\section{APÊNDICE B \\ PROTOCOLO INICIAL DE PESQUISA}

\section{Visão Geral do Projeto de Estudo de Caso}

$\underline{\text { A- Título }}$

Variáveis de decisão de marketing em serviços de demanda não desejada.

B-Objetivo do Estudo

A dissertação tem por objetivo estudar o gerenciamento das variáveis de decisão de marketing em serviços de demanda não desejada.

\section{Procedimentos de Campo}

\section{A- Aspectos metodológicos}

Pesquisa de natureza exploratória com o uso do método de caso.

\section{B- Organizações}

Empresas atuantes no mercado brasileiro ofertantes de serviços de demanda não desejada, mais especificamente, ofertantes de seguro de vida.

\section{C- Unidade de análise}

Variáveis de decisão de marketing

D- Fontes de evidência

Entrevistas dirigidas

$\underline{\text { E- Instrumento de coleta }}$

Roteiro de pesquisa

$\underline{\text { F- Executores da pesquisa }}$

Pesquisadora - Camila Gil

Orientador: Marcos Cortez Campomar 


\section{Questões do Roteiro de Entrevista}

A- Dados da organização

1. Nome

2. Faturamento

3. Atuação

$\underline{\text { B- Dados do entrevistado }}$

1. Nome

2. Cargo

3. Formação

4. Atribuições na empresa

\section{C- Questões de iniciais}

- Estrutura do departamento de marketing

- Noção do conceito de demanda não desejada

1 - Produto

- Definição de produto para o entrevistado e para a organização (núcleo do serviço, serviços suplementares)

- Identificar o conjunto de serviços auxiliares/suplementares

- Importância dos elementos físicos e sua definição

2 - Preço

- Estratégia de definição de preços adotada pela companhia

- Distinção de preços de acordo com os serviços suplementares

3 - Distribuição

- Identificar de que forma o serviço é vendido

- Existência de intermediários e seu papel

- Forma de monitoramento dos intermediários

- Estrutura (pessoas, tecnologia, equipamentos) envolvida no processo de distribuição 
4 - Comunicação

- Identificar as ferramentas de comunicação utilizadas para fazer a comunicação do seguro de vida

- Relevância de cada uma das ferramentas

- Objetivo da comunicação

- Estrutura de campanhas publicitárias recentes

- Argumentos utilizados na comunicação

\section{Análise do estudo de caso}

Relatório descritivo além da comparação entre a fundamentação teórica e os elementos encontrados a partir do caso. 


\section{APÊNDICE C \\ PROTOCOLO FINAL DE PESQUISA}

\section{Visão Geral do Projeto de Estudo de Caso}

$\underline{\text { A- Título }}$

Variáveis de decisão de marketing em serviços de demanda não desejada.

B-Objetivo do Estudo

A dissertação tem por objetivo estudar o gerenciamento das variáveis de decisão de marketing em serviços de demanda não desejada.

\section{Procedimentos de Campo}

\section{A- Aspectos metodológicos}

Pesquisa de natureza exploratória com o uso do método de caso.

\section{B- Organizações}

Empresas atuantes no mercado brasileiro ofertantes de serviços de demanda não desejada, mais especificamente, ofertantes de seguro de vida.

\section{C- Unidade de análise}

Variáveis de decisão de marketing

D- Fontes de evidência

Entrevistas dirigidas

$\underline{\text { E- Instrumento de coleta }}$

Roteiro de pesquisa

$\underline{\text { F- Executores da pesquisa }}$

Pesquisadora - Camila Gil

Orientador: Marcos Cortez Campomar 


\section{Questões do Roteiro de Entrevista}

A- Dados da organização

1. Nome

2. Faturamento

3. Atuação

$\underline{\text { B- Dados do entrevistado }}$

1. Nome

2. Cargo

3. Formação

4. Atribuições na empresa

\section{C- Questões de iniciais}

- Estrutura do departamento de marketing

- Noção do conceito de demanda não desejada

- Como se dá o gerenciamento das variáveis de decisão

1 - Produto

- Identificar a essência do que está sendo ofertado pela organização a seus clientes

- Definição de produto para o entrevistado e para a organização (núcleo do serviço, serviços suplementares)

- Identificar o conjunto de serviços auxiliares/suplementares

- Importância dos elementos físicos e sua definição

2 - Preço

- Estratégia de definição de preços adotada pela companhia

- Formas de pagamento

- Distinção de preços de acordo com os serviços suplementares

3 - Praça

- Identificar de que forma o serviço é vendido

- Existência de intermediários e seu papel 
- Forma de monitoramento dos intermediários

- Estrutura (pessoas, tecnologia, equipamentos) envolvida no processo de distribuição

4 - Promoção

- Identificar as ferramentas de comunicação utilizadas para fazer a comunicação do seguro de vida

- Relevância de cada uma das ferramentas e seu papel

- Objetivo da comunicação

- Estrutura de campanhas publicitárias recentes

- Argumentos utilizados na comunicação

- Entender as atividades promocionais

- Apreender a função da marca para a organização

\section{Análise do estudo de caso}

Relatório descritivo além da comparação entre a fundamentação teórica e os elementos encontrados a partir do caso. 
ANEXO

TÁBUA ATUÁRIAL - 2000 adotada na SUSEP

Legenda: $\mathrm{F}=$ Feminina $/ \mathrm{M}=$ Masculina

\begin{tabular}{|c|c|c|c|c|}
\hline $\begin{array}{c}\text { Idade do } \\
\text { participante } \\
\text { (em anos) }\end{array}$ & $\begin{array}{c}\text { AT-2000F } \\
\text { (Básica) }\end{array}$ & $\begin{array}{c}\text { AT-2000M } \\
\text { (Básica) }\end{array}$ & $\begin{array}{c}\text { AT-2000F } \\
\text { (Suavizada } \\
10 \% \text { ) }\end{array}$ & $\begin{array}{c}\text { AT-2000M } \\
\text { (Suavizada } \\
10 \% \text { ) }\end{array}$ \\
\hline 0 & 0,001794 & 0,002311 & 0,001615 & 0,002080 \\
\hline 1 & 0,000755 & 0,000906 & 0,000680 & 0,000815 \\
\hline 2 & 0,000392 & 0,000504 & 0,000353 & 0,000454 \\
\hline 3 & 0,000290 & 0,000408 & 0,000261 & 0,000367 \\
\hline 4 & 0,000232 & 0,000357 & 0,000209 & 0,000321 \\
\hline 5 & 0,000189 & 0,000324 & 0,000171 & 0,000291 \\
\hline 6 & 0,000156 & 0,000301 & 0,000141 & 0,000270 \\
\hline 7 & 0,000131 & 0,000286 & 0,000118 & 0,000257 \\
\hline 8 & 0,000131 & 0,000328 & 0,000118 & 0,000294 \\
\hline 9 & 0,000134 & 0,000362 & 0,000121 & 0,000325 \\
\hline 10 & 0,000140 & 0,000390 & 0,000126 & 0,000350 \\
\hline 11 & 0,000148 & 0,000413 & 0,000133 & 0,000371 \\
\hline 12 & 0,000158 & 0,000431 & 0,000142 & 0,000388 \\
\hline 13 & 0,000170 & 0,000446 & 0,000152 & 0,000402 \\
\hline 14 & 0,000183 & 0,000458 & 0,000164 & 0,000414 \\
\hline 15 & 0,000197 & 0,000470 & 0,000177 & 0,000425 \\
\hline 16 & 0,000212 & 0,000481 & 0,000190 & 0,000437 \\
\hline 17 & 0,000228 & 0,000495 & 0,000204 & 0,000449 \\
\hline 18 & 0,000244 & 0,000510 & 0,000219 & 0,000463 \\
\hline 19 & 0,000260 & 0,000528 & 0,000234 & 0,000480 \\
\hline 20 & 0,000277 & 0,000549 & 0,000250 & 0,000499 \\
\hline 21 & 0,000294 & 0,000573 & 0,000265 & 0,000519 \\
\hline 22 & 0,000312 & 0,000599 & 0,000281 & 0,000542 \\
\hline 23 & 0,000330 & 0,000627 & 0,000298 & 0,000566 \\
\hline 24 & 0,000349 & 0,000657 & 0,000314 & 0,000592 \\
\hline 25 & 0,000367 & 0,000686 & 0,000331 & 0,000616 \\
\hline 26 & 0,000385 & 0,000714 & 0,000347 & 0,000639 \\
\hline 27 & 0,000403 & 0,000738 & 0,000362 & 0,000659 \\
\hline 28 & 0,000419 & 0,000758 & 0,000376 & 0,000675 \\
\hline 29 & 0,000435 & 0,000774 & 0,000389 & 0,000687 \\
\hline 30 & 0,000450 & 0,000784 & 0,000402 & 0,000694 \\
\hline
\end{tabular}




\begin{tabular}{|c|c|c|c|c|}
\hline 31 & 0,000463 & 0,000789 & 0,000414 & 0,000699 \\
\hline 32 & 0,000476 & 0,000789 & 0,000425 & 0,000700 \\
\hline 33 & 0,000488 & 0,000790 & 0,000436 & 0,000701 \\
\hline 34 & 0,000500 & 0,000791 & 0,000449 & 0,000702 \\
\hline 35 & 0,000515 & 0,000792 & 0,000463 & 0,000704 \\
\hline 36 & 0,000534 & 0,000794 & 0,000481 & 0,000719 \\
\hline 37 & 0,000558 & 0,000823 & 0,000504 & 0,000749 \\
\hline 38 & 0,000590 & 0,000872 & 0,000532 & 0,000796 \\
\hline 39 & 0,000630 & 0,000945 & 0,000567 & 0,000864 \\
\hline 40 & 0,000677 & 0,001043 & 0,000609 & 0,000953 \\
\hline 41 & 0,000732 & 0,001168 & 0,000658 & 0,001065 \\
\hline 42 & 0,000796 & 0,001322 & 0,000715 & 0,001201 \\
\hline 43 & 0,000868 & 0,001505 & 0,000781 & 0,001362 \\
\hline 44 & 0,000950 & 0,001715 & 0,000855 & 0,001547 \\
\hline 45 & 0,001043 & 0,001948 & 0,000939 & 0,001752 \\
\hline 46 & 0,001148 & 0,002198 & 0,001035 & 0,001974 \\
\hline 47 & 0,001267 & 0,002463 & 0,001141 & 0,002211 \\
\hline 48 & 0,001400 & 0,002740 & 0,001261 & 0,002460 \\
\hline 49 & 0,001548 & 0,003028 & 0,001393 & 0,002721 \\
\hline 50 & 0,001710 & 0,003330 & 0,001538 & 0,002994 \\
\hline 51 & 0,001888 & 0,003647 & 0,001695 & 0,003279 \\
\hline 52 & 0,002079 & 0,003980 & 0,001864 & 0,003576 \\
\hline 53 & 0,002286 & 0,004331 & 0,002047 & 0,003884 \\
\hline 54 & 0,002507 & 0,004698 & 0,002244 & 0,004203 \\
\hline 55 & 0,002746 & 0,005077 & 0,002457 & 0,004534 \\
\hline 56 & 0,003003 & 0,005465 & 0,002689 & 0,004876 \\
\hline 57 & 0,003280 & 0,005861 & 0,002942 & 0,005228 \\
\hline 58 & 0,003578 & 0,006265 & 0,003218 & 0,005593 \\
\hline 59 & 0,003907 & 0,006694 & 0,003523 & 0,005988 \\
\hline 60 & 0,004277 & 0,007170 & 0,003863 & 0,006428 \\
\hline 61 & 0,004699 & 0,007714 & 0,004242 & 0,006933 \\
\hline 62 & 0,005181 & 0,008348 & 0,004668 & 0,007520 \\
\hline 63 & 0,005732 & 0,009093 & 0,005144 & 0,008207 \\
\hline 64 & 0,006347 & 0,009968 & 0,005671 & 0,009008 \\
\hline 65 & 0,007017 & 0,010993 & 0,006250 & 0,009940 \\
\hline 66 & 0,007734 & 0,012188 & 0,006878 & 0,011016 \\
\hline 67 & 0,008491 & 0,013572 & 0,007555 & 0,012251 \\
\hline 68 & 0,009288 & 0,015160 & 0,008287 & 0,013657 \\
\hline
\end{tabular}




\begin{tabular}{|c|c|c|c|c|}
\hline 69 & 0,010163 & 0,016946 & 0,009102 & 0,015233 \\
\hline 70 & 0,011165 & 0,018920 & 0,010034 & 0,016979 \\
\hline 71 & 0,012339 & 0,021071 & 0,011117 & 0,018891 \\
\hline 72 & 0,013734 & 0,023388 & 0,012386 & 0,020967 \\
\hline 73 & 0,015391 & 0,025871 & 0,013871 & 0,023209 \\
\hline 74 & 0,017326 & 0,028552 & 0,015592 & 0,025644 \\
\hline 75 & 0,019551 & 0,031477 & 0,017564 & 0,028304 \\
\hline 76 & 0,022075 & 0,034686 & 0,019805 & 0,031220 \\
\hline 77 & 0,024910 & 0,038225 & 0,022328 & 0,034425 \\
\hline 78 & 0,028074 & 0,042132 & 0,025158 & 0,037948 \\
\hline 79 & 0,031612 & 0,046427 & 0,028341 & 0,041812 \\
\hline 80 & 0,035580 & 0,051128 & 0,031933 & 0,046037 \\
\hline 81 & 0,040030 & 0,056250 & 0,035985 & 0,050643 \\
\hline 82 & 0,045017 & 0,061809 & 0,040552 & 0,055651 \\
\hline 83 & 0,050600 & 0,067826 & 0,045690 & 0,061080 \\
\hline 84 & 0,056865 & 0,074322 & 0,051456 & 0,066948 \\
\hline 85 & 0,063907 & 0,081326 & 0,057913 & 0,073275 \\
\hline 86 & 0,071815 & 0,088863 & 0,065119 & 0,080076 \\
\hline 87 & 0,080682 & 0,096958 & 0,073136 & 0,087370 \\
\hline 88 & 0,090557 & 0,105631 & 0,081991 & 0,095169 \\
\hline 89 & 0,101307 & 0,114858 & 0,091577 & 0,103455 \\
\hline 90 & 0,112759 & 0,124612 & 0,101758 & 0,112208 \\
\hline 91 & 0,124733 & 0,134861 & 0,112395 & 0,121402 \\
\hline 92 & 0,137054 & 0,145575 & 0,123349 & 0,131017 \\
\hline 93 & 0,149552 & 0,156727 & 0,134486 & 0,141030 \\
\hline 94 & 0,162079 & 0,168290 & 0,145689 & 0,151422 \\
\hline 95 & 0,174492 & 0,180245 & 0,156846 & 0,162179 \\
\hline 96 & 0,186647 & 0,192565 & 0,167841 & 0,173279 \\
\hline 97 & 0,198403 & 0,205229 & 0,178563 & 0,184706 \\
\hline 98 & 0,210337 & 0,218683 & 0,189604 & 0,196946 \\
\hline 99 & 0,223027 & 0,233371 & 0,201557 & 0,210484 \\
\hline 100 & 0,237051 & 0,249741 & 0,215013 & 0,225806 \\
\hline 101 & 0,252985 & 0,268237 & 0,230565 & 0,243398 \\
\hline 102 & 0,271406 & 0,289305 & 0,248805 & 0,263745 \\
\hline 103 & 0,292893 & 0,313391 & 0,270326 & 0,287334 \\
\hline 104 & 0,318023 & 0,340940 & 0,295719 & 0,314649 \\
\hline 105 & 0,347373 & 0,372398 & 0,325576 & 0,346177 \\
\hline 106 & 0,381520 & 0,408210 & 0,360491 & 0,382403 \\
\hline
\end{tabular}




\begin{tabular}{|c|c|c|c|c|}
\hline 107 & 0,421042 & 0,448823 & 0,401054 & 0,423813 \\
\hline 108 & 0,466516 & 0,494681 & 0,447860 & 0,470893 \\
\hline 109 & 0,518520 & 0,546231 & 0,501498 & 0,524128 \\
\hline 110 & 0,577631 & 0,603917 & 0,562563 & 0,584004 \\
\hline 111 & 0,644427 & 0,668186 & 0,631645 & 0,651007 \\
\hline 112 & 0,719484 & 0,739483 & 0,709338 & 0,725622 \\
\hline 113 & 0,803380 & 0,818254 & 0,796233 & 0,808336 \\
\hline 114 & 0,896693 & 0,904945 & 0,892923 & 0,899633 \\
\hline 115 & 1,000000 & 1,000000 & 1,000000 & 1,000000 \\
\hline
\end{tabular}

FONTE: disponível na http://www.susep.gov.br/menumercado/tabua.asp 